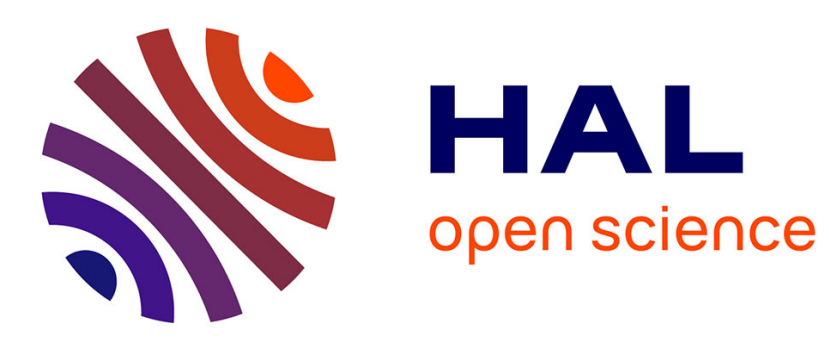

\title{
Brine grades in Andean salars: When basin size matters A review of the Lithium Triangle
} Romina Lucrecia López Steinmetz, Stefano Salvi

\section{To cite this version:}

Romina Lucrecia López Steinmetz, Stefano Salvi. Brine grades in Andean salars: When basin size matters A review of the Lithium Triangle. Earth-Science Reviews, 2021, 217, pp.103615. 10.1016/j.earscirev.2021.103615 . hal-03204125

\section{HAL Id: hal-03204125 \\ https://hal.science/hal-03204125}

Submitted on 21 Apr 2021

HAL is a multi-disciplinary open access archive for the deposit and dissemination of scientific research documents, whether they are published or not. The documents may come from teaching and research institutions in France or abroad, or from public or private research centers.
L'archive ouverte pluridisciplinaire HAL, est destinée au dépôt et à la diffusion de documents scientifiques de niveau recherche, publiés ou non, émanant des établissements d'enseignement et de recherche français ou étrangers, des laboratoires publics ou privés. 


\section{Journal Pre-proof}

Brine grades in Andean salars: When basin size matters A review of the Lithium Triangle

Romina Lucrecia López Steinmetz, Stefano Salvi

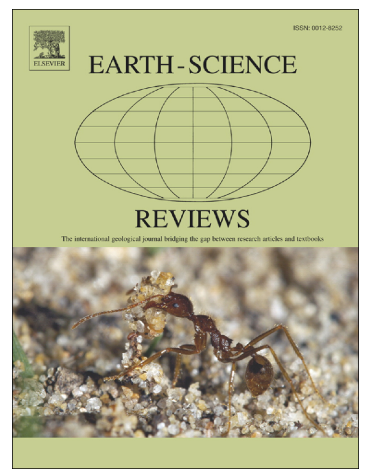

PII: $\quad$ S0012-8252(21)00115-X

DOI: $\quad$ https://doi.org/10.1016/j.earscirev.2021.103615

Reference: $\quad$ EARTH 103615

To appear in: $\quad$ Earth-Science Reviews

Received date: $\quad 16$ May 2020

Revised date: $\quad 9$ February 2021

Accepted date: $\quad 27$ March 2021

Please cite this article as: R.L.L. Steinmetz and S. Salvi, Brine grades in Andean salars: When basin size matters A review of the Lithium Triangle, Earth-Science Reviews (2021), https://doi.org/10.1016/j.earscirev.2021.103615

This is a PDF file of an article that has undergone enhancements after acceptance, such as the addition of a cover page and metadata, and formatting for readability, but it is not yet the definitive version of record. This version will undergo additional copyediting, typesetting and review before it is published in its final form, but we are providing this version to give early visibility of the article. Please note that, during the production process, errors may be discovered which could affect the content, and all legal disclaimers that apply to the journal pertain.

(C) 2021 Published by Elsevier B.V. 
Brine grades in Andean salars: when basin size matters A review of the Lithium

\title{
Triangle
}

Romina Lucrecia López Steinmetz ${ }^{1, *}$ lucrecialopezsteinmetz@hotmail.com, Stefano Salvi ${ }^{2}$ stefano.salvi@get.omp.eu

${ }^{1}$ IDEVEA (CONICET - UTN), Av. GRAL. J.J. Urquiza 314, 5600 San Rafael, Mendoza, Argentina

${ }^{2}$ University of Toulouse, CNRS, GET, IRD, OMP, 14 A . E touard Belin, Toulouse 31400, France

*Corresponding author

\begin{abstract}
The Lithium Triangle, a zone of the L. ntral Andes characterized by the presence of lithium (Li)-rich salt pans within endorhein $b \cdot{ }^{\prime} \cdot n s$, has gained a worldwide reputation chiefly due to its exceptional Li brine-type depusits. We summarize scientific hydrochemical reports, totalizing a data set comno ar of 477 brine samples across the Lithium Triangle. Brine compositions are predu. ${ }^{n}$ urantly of the $\mathrm{Cl}^{-}-\mathrm{SO}_{4}{ }^{2-} / \mathrm{Na}^{+}-\mathrm{Mg}^{2+}$ type, however, major brine chemistry and $\mathrm{Li}^{+}$grades vary across the Andean plateau. Brine compositions show some degree of geographic organization but no clear pattern was observed in the $\mathrm{Li}^{+}$distribution across the plateau. We highlight an interdependency between the areal surfaces of salt pans and endorheic basins, which, related to $\mathrm{Li}$ concentrations, show the following linear proportions: 1) a 1:5 to $1: 10$ proportionality between the surfaces of basin catchments and those of salt pans; 2) a 2:1 proportionality between maximum and mean Li values; the latter implies that the equation mean $\mathrm{Li} \approx 1 / 2 \max \mathrm{Li}$ can be employed to predict indicative mean
\end{abstract}


grades during Li surveys in the Central Andes. In addition, the concentrations of Li can be addressed with respect to the area of salt pans and/or its basin catchments: it would be not only the largest, but also the oldest salars that are expected to hold the greatest $\mathrm{Li}$ concentrations. Finally, the area involving all salt pans in the Andean plateau is more than three times the size of what is known as the Lithium Triangle and has a curved crescent shape; we thus propose referring to it in the future as the Lithium Crescent.

Keywords: salt pan; endorheic basin; hydrochemistry; Andes

\section{Introduction and historical background}

The demand for lithium (Li) has recently knowl a great increase worldwide due to its application in the fabrication of recharge b. ' ', atteries (for mobile phones, personal computers, electric vehicles, etc.). Knc'vn global lithium resources involve about $31 \mathrm{Mt}$, which would represent $\sim 1.50$ times the slobal estimated demand up to the year 2100 (Kesler et al., 2012). Nowadays, lithium i` $\mathrm{m} \rightsquigarrow$.ly obtained from pegmatite- and brine-type deposits. The former consist of conve i ionai Li mining and represent $\sim 4 \mathrm{Mt}(\sim 13 \%)$ of estimated resources. Apart from and . dr itional 5 to $6 \mathrm{Mt}$ potential production from hydrothermal solutions and oilfields 'Kcsler et al., 2012), the remaining $\sim 2 / 3(\sim 68 \%)$ of global lithium resources are contained in brine-type deposits. This makes them indispensable to meet the growing demand and has caused Li-rich salars to attain the status of an economically, technologically and geopolitically strategic resource (Garrett, 2004; Gruber and Medina, 2010; Mohr et al., 2010; Houston et al., 2011; Kesler et al., 2012; López Steinmetz and Fong, 2019).

$\mathrm{Li}$ is a relatively abundant element on Earth with a concentration in the upper continental crust of about $35 \pm 11$ ppm (Teng et al., 2004). As Li is a very reactive and 
geochemical incompatible element, it is commonly present in natural waters as a solute, in its ionic form, $\mathrm{Li}^{+}$. The mean $\mathrm{Li}$ concentration in sea water is $0.18 \mathrm{mg} \mathrm{L}^{-1}$ (Riley and Tongudai, 1964), whereas continental waters are characterized by highly variable Li values. Salt pans (salars or salt flats, desert areas where salts accumulate) in arid regions of the globe store brines that contain Li concentrations often averaging two to three orders of magnitude above those in sea water. Most brine-type deposits involve concentrations of more than $400 \mathrm{mg} \mathrm{L}^{-1}$ of Li.

The Andean plateau in South America, one of the most nec.liar geological features on Earth, has gained a worldwide reputation due to its except $\mathrm{OH}^{\prime} \mathrm{l} \mathrm{Li}$ brine-type deposits (Kesler et al., 2012). The constraints imposed by environmentaı hallenges and the need for strong technological developments to replace fossil fuels ar global factors that have driven the Andean Li rush during now more than a decac. Jnder the effect of the lithium rush, the plateau region became known as "The ith um Triangle". This was an informal appellation originally designating the area compris $\mathrm{f}$ between the Salar de Atacama in Chile (\#12 in Fig. 1), the principal Li mine in the wnrlc (Moraga et al., 1974; Ide and Kunasz, 1989; Kunasz, 2006), the Salar de Uyuni (\#3) ๆ Bulivia to the north (Ericksen and Salas, 1987; Risacher and Fritz, 1991), and the Salar de H'mbre Muerto (\#43) in Argentina to the south (Godfrey et al., 2013) (Fig. 1). This a 'inutation of the Andean Lithium Triangle then became established based on the relevance of these three salars, which have been the most important Li spots during the last years. However, there are several more Li-bearing salt pans in this Andean region, many of which located outside of this triangle (Fig. 1). In addition, the nonscientific literature (i.e., diverse press articles, NI reports of mining prospects, etc.) commonly considers all the Andean salt flats as containing significant amounts of $\mathrm{Li}$, although data on brine hydrochemistry, including Li grades, are still quite limited, to this date. Therefore, we consider it is important to delimit the area containing all known salt pans. As shown in Figure 
$1 \mathrm{~b}$, such region (in green) corresponds to a curved crescent shape of more than three times the size of the Triangle (in pink), to which we propose referring to as the Lithium Crescent.
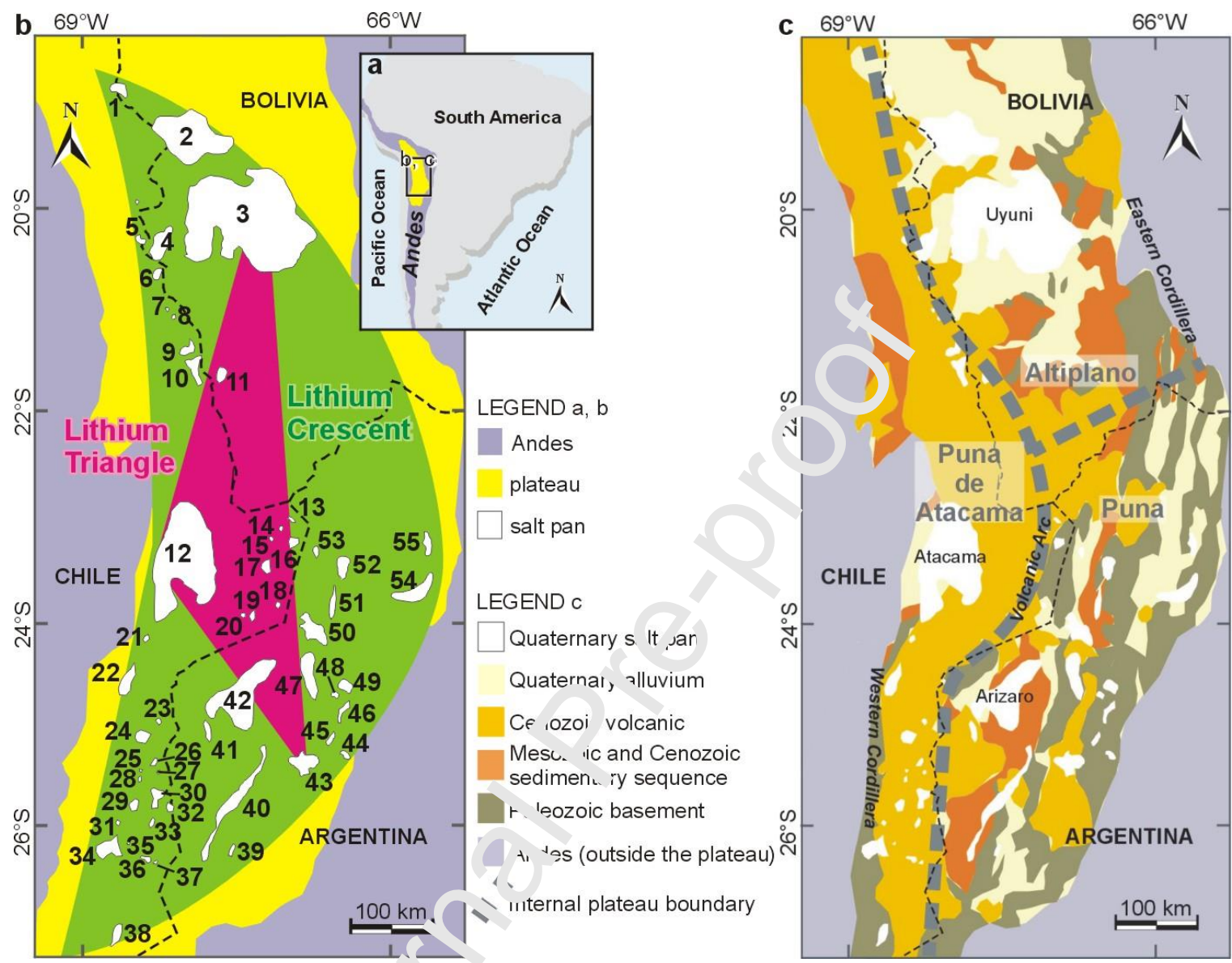

Figure 1. Simplified maps how ing the location of a) the Andean plateau and b) salt pans, the Lithium Triangle (pink) and proposed Lithium Crescent (green) corresponding to the area involving all salt pai $0_{2}$ th : plateau. c) Simplified lithological map of the Andean plateau (modified from Allmencinger et al., 1997), showing the location of the Puna, Puna de Atacama and Altiplanı. Dashed black lines represent national borders. Salt pans are numbered in panel $\mathrm{b}$ as in Table 1 .

The interest for Andean salt pans and their resources began almost a century ago. The first studies were conducted across the Puna de Atacama in northern Chile by geoscientists of the USGS (United States Geological Survey). To this early period of hydrological and geochemical surveys correspond the reports made by Clark (1924), Ericksen (1961, 1963), and Dingman (1967). A few years later, during the 70's, lithium was already perceived as an important resource, as reveals the book "Lithium Resources and Requirement by the year 
2000" edited in 1976 by James Vine (also of the USGS). Some of the chapters in this book have become milestone contributions on the topic (e.g., Ericksen et al., 1976b; Kunasz, 1976). During this period, the Chilean State started having an active role on the geological surveying of the Puna de Atacama (the Chilean and western part of the Andean plateau), and on the study of the hydrochemistry of the Salar de Atacama (Moraga et al., 1974; Vila, 1975). Exploration of Andean salars and their Li resources formally began in 1975, when the Chilean State, in association with private companies, conducted the first formal survey of the Salar de Atacama (Kunasz, 1976). Simultaneously, the USGS announerd the first results of analyses on two brines samples from the Salar de Uyuni, revealin $f_{L}:$ concentrations as high as 490 and $1,510 \mathrm{mg} \mathrm{L}^{-1}$ (Ericksen et al., 1976a, 1976b). Sinc: those times, Atacama and Uyuni founded the biggest expectations on the emerging interest in Li-brine type deposits (Mardones, 1986).

The role of the USGS in generati. $\sigma t^{\prime}$ e fundamental knowledge on the hydrochemistry of Andean salt pans, especially in the r.na de Atacama but also in the Bolivian Altiplano (see Ericksen et al., 1977), remained pradc n nant for more than half a century and continued up to the end of the 80's (see Stoert_ and Ericksen, 1974; Ericksen and Salas, 1977; Ericksen et al., 1978; Ericksen and Salas. 198 ; Ide and Kunasz, 1989). The two following decades were characterized by the a ruisition of vast hydrochemical data sets of many Chilean salars (Alonso and Risacher, 1996; Risacher and Alonso, 1996; Risacher et al., 2003) and Uyuni (Risacher and Fritz, 1991; Risacher and Fritz, 2000; Risacher and Frits, 2009; Lowenstein and Risacher, 2009). These new major contributions, which included for example the hydrochemical characterization of more than 170 brine samples across the entire Uyuni (Risacher and Fritz, 1991), were in charge of a French-Chilean council headed by Professors François Risacher of the IRD (Institut de Recherche pour le Development, France) and Hugo Alonso of the UCN (Universidad Católica del Norte, Chile). From this French-Chilean 
collaboration emerged the hydrochemical data available today on the Puna de Atacama and Altiplano salt pans, and which remain currently used by COCHILCO (Corporation Chilena del Cobre, the Chilean public society owning mining properties for $\mathrm{Cu}, \mathrm{Li}$ and other metals in Chile). Additional hydrological and hydrochemical studies, including isotopic assessments in salars and hydrothermal springs in the Puna de Atacama and Altiplano, have been conducted during the last years (e.g., Carmona et al., 2000; Boschetti et al., 2007; Vasquez et al., 2013; Boutt et al., 2016; among others). It was only concurrently to these recent studies that the lithium prospection started along the southeastern side of the Cantı. ${ }^{1}$ Andes.

Salars in the Puna (i.e., the Argentine portion of At Andean plateau) have received much less attention that those in the Puna de Atacama $a_{1}{ }^{-1}$ Altiplano. It was probably due to the major attraction caused by the enormous Li l sources that stores Atacama (with exceptional Li mean concentrations of $1,400 \mathrm{~m}_{\mathrm{L}_{2}} \mathrm{I}^{1}$; Moraga et al., 1974; Ide and Kunasz, 1989; Kunasz, 2006), and perhaps also $\mathrm{C}^{\prime} \mathrm{e}+\mathrm{s}$ the blinding expectations triggered by a salt pan having such a giant dimension as Uy -ni $\left(10,580 \mathrm{~km}^{2}\right)$. It remains that the Puna salt pans stayed almost unexplored up to $0^{n 1} y$, secade ago, despite the recent context of the Andean lithium rush. The first hydrochs mical studies were conducted locally on a few salars: the Salar del Rincón (\#50; Ovejero ivlf do et al., 2009), Salar de Hombre Muerto (Godfrey et al., 2013), Olaroz (\#52; L rrua et al., 2016; Franco et al., 2016), Guayatayoc (\#55; López Steinmetz, 2017), and the first isotopic data on the Salar de Ratones (\#45), Centenario (\#46), and Olaroz (Orberger et al., 2015; García et al., 2019; Franco et al., 2020). A broad survey of the Li-bearing salars in the Puna plateau was only recently accomplished, by geoscientist of the Argentine State, who investigated the brine hydrochemistry for the 17 major salars of this part of the Central Andes (López Steinmetz et al., 2018; López Steinmetz et al., 2020a). Because of this long-lasting lack of information, so far it has not been possible to address the hydrochemistry of Andean salt pans in a regional perspective, i.e., in a spatial-geographical 
sense, which implies having an overview of all of these salt pans together. Almost a century after the first USGS surveys, the last surveying achievements in the Puna salars finally give us the opportunity of compiling the existing data set and globally assess the hydrochemistry of the Lithium Crescent.

Li-bearing Andean salt pans are exclusively hosted in endorheic basins (isolated hydrological units corresponding to internally drained areas). The onset of endorheism in the Andean plateau established in the Neogene, associated with the creation of orographic deserts within intermontane settings in response to plateau uplift, as wer. as widespread volcanism (Alonso et al., 1991; Vandervoort et al., 1995; Alonso f ‘ a' L006; López Steinmetz et al. 2020b). The formation of endorheic basins and salt na:s is a function of the spatial and temporal distribution of the topographic configuration, s 'dimentation and erosional processes, as well as climate (Sobel et al., 2003; Hilley aı 1 s trecker, 2005; García-Castellanos, 2006; Garreaud, 2009; Tremblay et al., 2015, Ić sez Steinmetz et al., 2020b). One might suspect that, under analogous climatic and geoingical conditions, whichever they may have been, the larger a basin catchment, the larrer $h$ s size (and volume; i.e. depth) of the salt pan. But because Earth and its proce i ses are typically multi-dimensionally (4D, space - time), heterogeneous and complex 'B :cker and Braun, 1999; Paola et al., 2009), this relationship cannot be taken for gra. ${ }^{+}{ }^{4}$. One of the objectives of the present contribution is to address the interdependency between the areal surfaces (size) of salt pans and of their endorheic basins and relate them to Li grades within an Andean perspective. Remarkably, our findings indicate that this size function follows in fact a proportional ratio across the Andean plateau.

No clear geographical pattern in Li distribution (nor concentration) has been found across the Lithium Crescent (López Steinmetz et al., 2020a), except that maximum Li concentrations have been reported from salt pans located in the center of the plateau (Fig. 1). Similarly, consistently with the latest studies on this area (Egenhoff and Lucassen, 2003; 
Peralta Arnold et al. 2017; García et al., 2019; Meixner et al., 2019), our observations rule out a geographical control on the primary source of Li (and its concentration), and suggest that a combination of basin-scale processes and endorheic surface sizes control, at least in part, Li grades. It is likely that the lithological characteristics of each salar will have contributed to its geochemical composition. However, to our knowledge, no such study has been carried out yet. Figure 1c shows a synthetic view of lithologies underlying salt pans in the Andean plateau. Any given salar sits on several units, which influence the specific input of the lithology on a salar's chemical signature that are in also prohabı, controlled by more large basin-scale processes like hydrothermalism.

In addition to the salar/basin size function surther objectives of the present contribution are: - to summarize the hydrochemical da ${ }^{\urcorner}$sets of brines from salt pans at the Andean scale; - to identify regional patterns (i e., sn „tial-geographical) for Li distribution and brine concentrations; - to recognize 'se'ul criteria (e.g., hydrochemical, geographical, geomorphological, etc.) for surveying ( f Li-brine type deposits; - to discuss in absolute and comparative terms the relevance and n'tential of Andean prospects. A better knowledge of the salars in this region of tis andes and of their Li endowment will necessarily prove beneficial for a better goverı $n$, e of natural resources, whether it be administrative exercise, private sector investme. ${ }^{+}$suategies, or simply contributing to the public knowledge.

\section{Geology of the Andean Plateau}

The Andes display along the western South America (Fig. 1). The Orogenic processes that conducted to the Andes mountain building started in the early Cenozoic after major reorganization of tectonic plates in the eastern Pacific, driving the convergence of the Nazca and South American plates (Tassara, 2005, and references therein). 
The Andean plateau (Fig. 1 B) is a tectonic elevation area settled in the Central Andean zone. It occupies parts of northern Chile and Argentina, western Bolivia and southernmost Peru. The plateau involves the internally drained basins of the Central Andes (Allmendinger et al., 1997), which largely correspond to the areas settled above the $3 \mathrm{~km}$ elevation contour (Isacks, 1988).

The plateau involves a $>60-70 \mathrm{~km}$-thick crust and thin lithosphere (without or with very thin lithospheric mantle, see Allmendinger et al., 1983; Coira et al., 1993; Allmendinger and Gubbels, 1996; Whitman et al., 1996). The plateau is fla. ked to east and west by morphotectonic units of the continental plate, the Eastern Illi Western Cordilleras (Fig. $1 \mathrm{C}$ ), whereas in the N-S direction the plateau extent coincide with abrupt dip changes along the subduction zone, from flat $\left(<10^{\circ}\right)$ to normal $\left(\sim 30^{\circ}\right) s u_{\iota}$ duction, and with the intersection of the Nazca and Juan Fernández oceanic ridge; ‘arsara, 2005, and references therein). The Eastern Cordillera reaches 5-6 km eleva , n and it is a doubly-vergent deformation belt active until the middle-late Miocene (Heran at al., 1996; McQuarrie, 2002). South of $27^{\circ} \mathrm{S}$, the tectonic style of the Eastern Cordil ara transitions to uplifted basement blocks made of crystalline Palaeozoic rocks a. 1 the Sierras Pampeanas (Ramos et al., 2002). The Western Cordillera is an Eocene ma $a_{\varepsilon}^{-m}$ tic and tectonic belt (Mpodozis and Ramos, 1989) that is related to a west-verg $n$ t ulrust system (WTS, Muñoz and Charrier, 1996). The Western Cordillera has peaks that rise to $\sim 6 \mathrm{Km}$-in-high and involves stratovolcanoes of Miocene and younger age at the margin of the plateau (Jordan et al., 2010).

The geological characteristics of the Andean plateau vary along-strike. Internal plateau changes on topography, volcanism, tectonic style and subduction conditions, among others relevant aspects, have led to identify major internal plateau subdivisions: the Altiplano $\left(15^{\circ}-\right.$ $\left.22^{\circ} \mathrm{S}\right)$, the Puna $\left(22^{\circ}-27^{\circ} \mathrm{S}\right)$ and the Puna de Atacama (east of the volcanic arc) (Jordan et al. 1983, Mpodozis and Ramos, 1989; Fig. 1 C). The Puna - Altiplano transition occurs at $\sim 22^{\circ}$ S. 
The Altiplano is characterized by a broad, low-relief, with a mean elevation of $\sim 3.8 \mathrm{~km}$. The Puna lies at an average elevation nearly a kilometer higher than the Altiplano, holds younger mafic magmatism (Maro et al., 2017), and its physiography involves several endorheic depressions bounded by basement-cored ranges (Whitman et al., 1996, Allmendinger et al., 1997, Jordan et al., 2010). The volcanic arc displays nearby N-S and separates the AltiplanoPuna on the eastern side of the plateau from the Puna de Atacama in the west. The volcanic arc (also known as the CVZ, the acronym for Central Volcanic Zone, $15^{\circ}-28^{\circ} \mathrm{S}$ ) is a chain of Miocene to Quaternary stratovolcanic complexes and andesiti^-rh, Jdacitic domes of high-K calcalkaline affinities (Allmendinger et al., 1997; Kay et ıl., 1999, Jordan et al., 2010). The Puna de Atacama sets west of this volcanic arc and in. nlves the Atacama basin, a major topographic and geologic anomaly that is one of sevsra anomalous features occurring across the plateau margin at this latitude (Schurr et al., 1r99; Götze and Krause, 2002; Belmonte, 2002).

From a stratigraphic point of vl $v$, the plateau is filled with synorogenic deposits that record clastic, volcanic, and evaprmati $*$ Cenozoic episodes (Allmendinger et al., 1997; Baby et al., 1997; McQuarrie, 2002, Alonso et al., 2006). Most of compressive deformation and plateau uplift occurred in the $\mathbf{M}$ ocene and Pliocene all together with major felsic magmatism in the region. Large vo: rnıes of dacitic ignimbrites (over $104 \mathrm{~km}^{3}$ erupted volume) erupted from caldera complexes located in and to the east of the arc conducted to Altiplano-Puna plateau to be the largest Neogene ignimbrite province in the world (Babeyko et al., 2002, and references therein).

The plateau basement largely consist of Ordovician, and, locally, older metasedimentary marine, plutonic and volcanic rocks. Basement rocks dominate the outcrop along uplifted ranges. The basement is unconformable overlain by sparse exposures of marine calcareous sequences that record the Cretaceous - Paleocene rift basins. These deposits 
correspond to the Salta Group (Brackebusch, 1883, 1891; nom. transl. Turner, 1959) in the Puna and its northwards equivalent Supersequences Puca and Coro-Coro (Sempere et al., 1997) in the Plateau and Western Cordillera of the Bolivian Andes.

Diachronic deformation (Hongn et al., 2007) drove Andean deposition in emergent continental basins. Cenozoic basin fill typically involves red beds, conglomerates and playa deposits containing interlayered evaporites and tuffs. Andean sequences resulted from sedimentation in interconnected and isolated basins during the evolving Andean foreland system (Lopez Steinmetz and Montero-Lopez, 2019, Montero-I op:z et al., 2020, Adad et al., 2020, and references therein). Regional isolation has strer.gi oned once the plateau raised in the Mio-Pliocene. This period was characterized by a flan -up magmatism, regional uplift and the establishment of generalized endorheism (Isacks 1, <8; Kay et al., 1994, Allmendinger et al., 1997; Garzione et al., 2008, 2017, Gianni e 11 , 2020). The plateau rise and the Andean

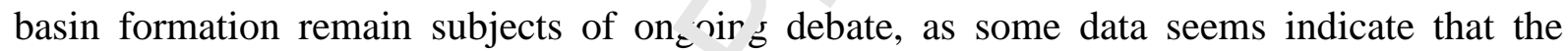
formation of the high plateau, endor heism and intermontane basins could have started together and as early as the Palang $n$ : (Canavan et al., 2014; Scott et al., 2018, López Steinmetz et al., 2020c). Quatc: nary alluvium covers the low-laying planes between mountain ranges and volcanoes. Halite $d$ Jminated pans, locally known as salares and salinas, formed because of the extreme, arid climatic conditions that prevail in these high-altitude endorheic basins since at least the Miocene (Alonso et al., 2006).

\section{Material and Methods}

The dataset in this article comprises two types of information: 1) major hydrochemistry including Li concentrations in brines from Andean salt pans, and 2) the areal surface (size) of these salt pans and of their basin catchments. The hydrochemical and Li data were obtained by compiling available information for 49 Andean salt pans published in the 
scientific literature. All the areal surfaces of salt pan and respective basin catchments were obtained from satellite imagery. These values consist of geomorphological considerations of areal surfaces for 55 salt pans and their basin catchments, which include the 49 salt pans for which Li data were obtained, plus 6 additional salt pans from which there is no available hydrochemical information (i.e., Salar Grande, Capur, Los Infieles, Salar de la Laguna, La Piedra Parada, and Wheelwright). Surface sizes are summarized in Table 1. Salt pan locations are shown in Figure 1 and detailed in Table A1 of the Electronic Supplementary Data.

As detailed in the historical context outlined in Section $1 \mathbb{1}_{\mathrm{t}}$ is important to realize that the survey of Andean Li has involved a long period of da' a a ${ }^{`}$ quisition and that the available brine chemistry dataset emerged from diachronic samnlı. o campaigns conducted by various scientists during different periods: 1) in most cases, the - rine dataset from a particular salt pan results from a unique sampling campaign (i. ., in longitudinal sampling variation data are available), and 2) from a regional point . f vew (i.e., Andean plateau scale), when comparing the brine chemistry of different salt par. datasets are composed by diachronic sampling from one salt pan to the other. These as ${ }_{1}$ its imply disparate frameworks for time-dependent conditions that can influence he sampling and analytical methodology. Examples include climate (which controls salı ${ }^{\circ}$ saturation of brines regulating $\mathrm{Li}$ concentrations), sampling

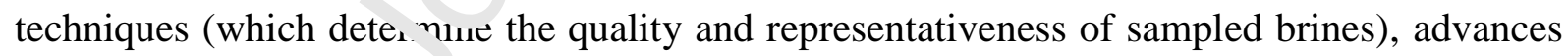
in analytical methodologies (which define hydrochemical data quality), etc. Therefore, we made sure to be particularly careful when assessing the validity of each dataset included in our regional brine hydrochemistry compilation: we only considered peer-reviewed scientific articles to construct our dataset.

The hydrochemical data compiled in this review (Table 2) correspond exclusively to residual brines from salt pans. Care was taken to exclude values from springs, rivers or streams from the dataset. In most cases, samples correspond to shallow and sub-surface brines 
that were collected from hand-dug pits in the salt pans, i.e., at depths less than $1 \mathrm{~m}$. In a few cases, samples were taken directly from brine pools (i.e., ponding brines) that had formed naturally in the salars (Risacher et al., 199; Lopez Steinmetz et al., 2018; 2020). Data considered for the Uyuni and Coipasa salars, in addition to near-surface brines, consists also of a collection of samples obtained at depths of up to $10 \mathrm{~m}$ from 40 holes dug in the salt crust of these salars. In Table 2, the sampling depths (in centimeters) are indicated by numbers in names of the 176 samples from Uyuni and Coipasa (for more details see Risacher and Fritz, 1991). Due to the regional scale of this review and, as just me.tioned, the fact that most considered brines come from sampling within the salt pan, ti. specific location and depth of each of the 477 brines constituting our dataset (Table ?) : re not reported here. In Table 2 all samples are grouped by salt pans which are locater 11 . Figure 1 and whose coordinates are provided in Table A1 of the Electronic Suprle er ary Data. In the following lines of this section, all references are provided to th scentific literature considered, as well as details on criteria for building the dataset. For further information on the sampling and analytical techniques deployed for specific data, ,r the specific location of each sample, the reader is referred to the original papers $\mathrm{i}$. $\mathrm{m}$ where the datasets were taken.

In this review, salt nács are grouped into Altiplano, Puna de Atacama and Puna salars, which is roughly equiva' ${ }^{\prime}$ II to say Bolivian, Chilean and Argentinian, respectively, given that national borders follow natural boundaries in the plateau (Fig. 1). Readers that are not familiar with Andean geography, can find more detailed discussion on Andean salt pans and brine chemistry in the references listed in the following paragraphs.

The hydrochemical data set (Table 2) involves 477 brines samples and is composed of: - 178 brine samples from the Altiplano salt pans that majorly correspond to data published by Risacher and Fritz (1991), and to a minor extent by Ericksen and Salas (1987), 
- 126 brine samples from the Puna salt pans (Ericksen and Salas, 1987; López Steinmetz, 2017; López Steinmetz et al., 2018; García et al., 2019; López Steinmetz et al., 2020a), and

- 173 brine samples from the Puna de Atacama salt pans reported by Moraga et al. (1974), Vila (1975), Ericksen and Salas (1987), and Risacher et al. (1999; summarized by COCHILCO, 2013).

For the case of the Salar de Atacama, we used samples $\mathrm{ATA}_{0}$ and ATA $\mathrm{do}_{\mathrm{do}}$, ATA, and Do1 to Do5 reported for Moraga et al. (1974) and Ericksen and Salas (1987), and ATA-05 and ATA-22 reported by Risacher et al. (1999), which are - to the iest of our knowledge - the only available published data on brine samples collected wr' $^{\prime}$ n this salt pan, and offering a complete spectrum of major ions, $\mathrm{Li}$, and TDS. It is jmb rtant to note that $\mathrm{Li}$ values that are either i) isolated, from incomplete ionic characteriz tı ns, or ii) from non-scientific reports, were not taken into consideration. According t s $\imath^{\prime}$ es $\_$criteria, the considered Li values are the unique, scientific published data of bri-e amples available from samples collected in the Andean salt pans, and offer a compste hydrochemical spectrum. Data reported in other scientific works correspond to inflnw ${ }^{\mathrm{N}}$ /ters and/or hydrothermal springs, and not to residual brines lying within these salt $\mathrm{f}^{\urcorner n s,}$ and/or do not offer a complete spectrum including TDS, major ions, and Li (i.e., Ericn'e' et al., 1976a, 1976 b; Crespo et al., 1987; Rettig et al., 1987; Scandiffio and Alvarez, 1๖>0; Scandiffio and Rodriguez, 1990; Mardones and Chong, 1991; Bevacqua, 1992; Garcés et al., 1996; López et al., 1996; Carmona et al., 2000; López Julián et al., 2001; Risacher et al., 2002; Banks et al., 2004; Vinante and Alonso, 2006; Boschetti et al., 2007; Ovejero Toledo et al., 2009; Salas et al., 2009; Schmidt, 2010; An et al., 2012; Durán Iriza, 2012; Vásquez et al., 2013; Boutt et al., 2016; Corenthal et al., 2016; Munk et al., 2018; Godfrey and Alvarez-Amado, 2020).

Mean brine compositions were computed from the information available, summarized in Table 3. In the case of the Salar de Atacama, we also considered values of 1,400 and 6,400 
$\mathrm{mg} \mathrm{L}^{-1}$ as the representative mean and maximum Li concentrations of the Atacama brines, respectively, as listed in Moraga et al. (1974; see also Ide and Kunasz, 1989; Kunasz, 2006). Accordingly, the hydrochemical and $\mathrm{Li}^{+}$concentrations of the Atacama brines (i.e., mean and maximum of 562 and 1,570 $\mathrm{mg} \mathrm{L}^{-1}$, respectively) from Moraga et al. (1974), Ericksen and Salas (1987), and Risacher et al. (1999) are used for general characterizations such as shown in Figures 2 to 6, however, we used the 1,400 and 6,400 $\mathrm{mg} \mathrm{L}^{-1}$ mean and maximum $\mathrm{Li}$ concentrations when assessing this major salar in its regional context (Figs. 9 and 10). Li maximum (max) and mean concentrations of $\mathrm{Li}^{+}$and $\mathrm{Mg}^{2+}$ in a. salars (Table 4) are also considered and discussed. Saturation indexes (SI) at sals tard ambient temperature and pressure (SATP, $25^{\circ} \mathrm{C}, 1 \mathrm{~atm}$ ) were computed using the treeqc 3.6.2 software, to address the saturation state of brines with respect to main salt. . he most representative ranges of SI values are reported in the Results section.

\section{Brine hydrochemistry across the L:}

\subsection{Altiplano salars}

A few salt pans occu: $i$, the southern Bolivian Altiplano. Amongst these salars, the most prominent are Uy, $\eta_{1}$ and Coipasa (\#2): with an area of $10,000 \mathrm{~km}^{2}$, Uyuni is by far the largest salt pan on Earth, and with its $1,650 \mathrm{~km}^{2}$ Coipasa is the fourth largest salar in the Andean plateau (Fig. 1, Table 1). Empexa (\#4 in Fig. 1) and Pastos Grandes (\#11) also are large salars with their 402 and $124 \mathrm{~km}^{2}$, respectively. These salt pans are located at altitudes $>3.60 \mathrm{~km}$ asl, and their catchments involve endorheic basins having disparate surfaces that range between 600 and 45,200 $\mathrm{km}^{2}$ (Table 1). None of these salt pans is yet being mined for lithium. 
The brine chemistry of Uyuni and Coipasa was thoroughly described by Risacher and Fritz (1991), whereas only two isolated samples are available from Empexa and Pastos Grandes (Ericksen and Salas, 1987; Table 2). The Altiplano salt pans contain highly saline brines with mean TDS (Total Dissolved Solids) values comprised between 123 and $321 \mathrm{~g} \mathrm{~L}^{-1}$ (Table 3), although in most cases TDS are in a range from 100 to $\sim 220 \mathrm{~g} \mathrm{~L}^{-1}$ (Risacher and Fritz, 1991; Table 2). The maximum TDS values reported are of $351 \mathrm{~g} \mathrm{~L}^{-1}$ and $368 \mathrm{~g} \mathrm{~L}^{-1}$, respectively from Uyuni and Coipasa (Ericksen and Salas, 1987).

Based on their major chemical compositions, brines in $\mathrm{I} y \cdot$. ni are of the $\mathrm{Mg}^{2+}-\mathrm{Na}^{+} /$ $\mathrm{Cl}^{-}-\mathrm{SO}_{4}{ }^{2-}$ type, with $\mathrm{Mg}^{2+} \geq \mathrm{Na}^{+}$, whereas in Coipasa, Em pe.. $\mathrm{\imath}$ and Pastos Grandes brines are of the $\mathrm{Na}^{+}-\mathrm{Mg}^{2+} / \mathrm{Cl}^{-}-\mathrm{SO}_{4}{ }^{2-}$ type, with $\mathrm{Na}^{+}>\mathrm{Mg}^{2+}$ (Fig. 2 and 3 a). Main characteristics of brines from Altiplano salars are their high $\mathrm{Mg}^{2+}$ concsnı 'tions and their relatively low $\mathrm{K}^{+}$and $\mathrm{Ca}^{2+}$. Stoichiometric ionic ratios between $\mathrm{Nc}^{+} \mathrm{nr}^{-} \mathrm{Cl}^{-}$are consistent with the equilibrium solubility of halite for a certain number ${ }^{f} t^{t}$ e Uyuni brines (i.e., SI $\approx 0$, e.g., samples RA130, RB180, RC120), however, a large nun.' 'er of them plot along an oblique line with respect to the 1:1 proportion (Fig. 3 b), suggasti ' $~$ that the brine reached saturation with respect to (and thus precipitated) halite (SI > C and up to 0.36, e.g., samples RX10, RZ1, CA150). Except for some samples from Coipasa (e g., CB150 and CA250), the fact that the $\mathrm{SO}_{4}{ }^{2-}: \mathrm{Mg}^{2+}$ ratio forms a trend $\mathrm{Mg}^{2+}>\mathrm{N}_{4}$ ? perpendicular to the $1: 1$ line, is in turn consistent with the saturation of the brines with respect to epsomite $\left(\mathrm{MgSO}_{4} 7 \mathrm{H}_{2} \mathrm{O}, \mathrm{SI}>0\right.$ and up to 0.73 , e.g., samples RZ1, RT15, RX10), and/or other Mg-bearing sulfated salts (Fig. 3 c). 


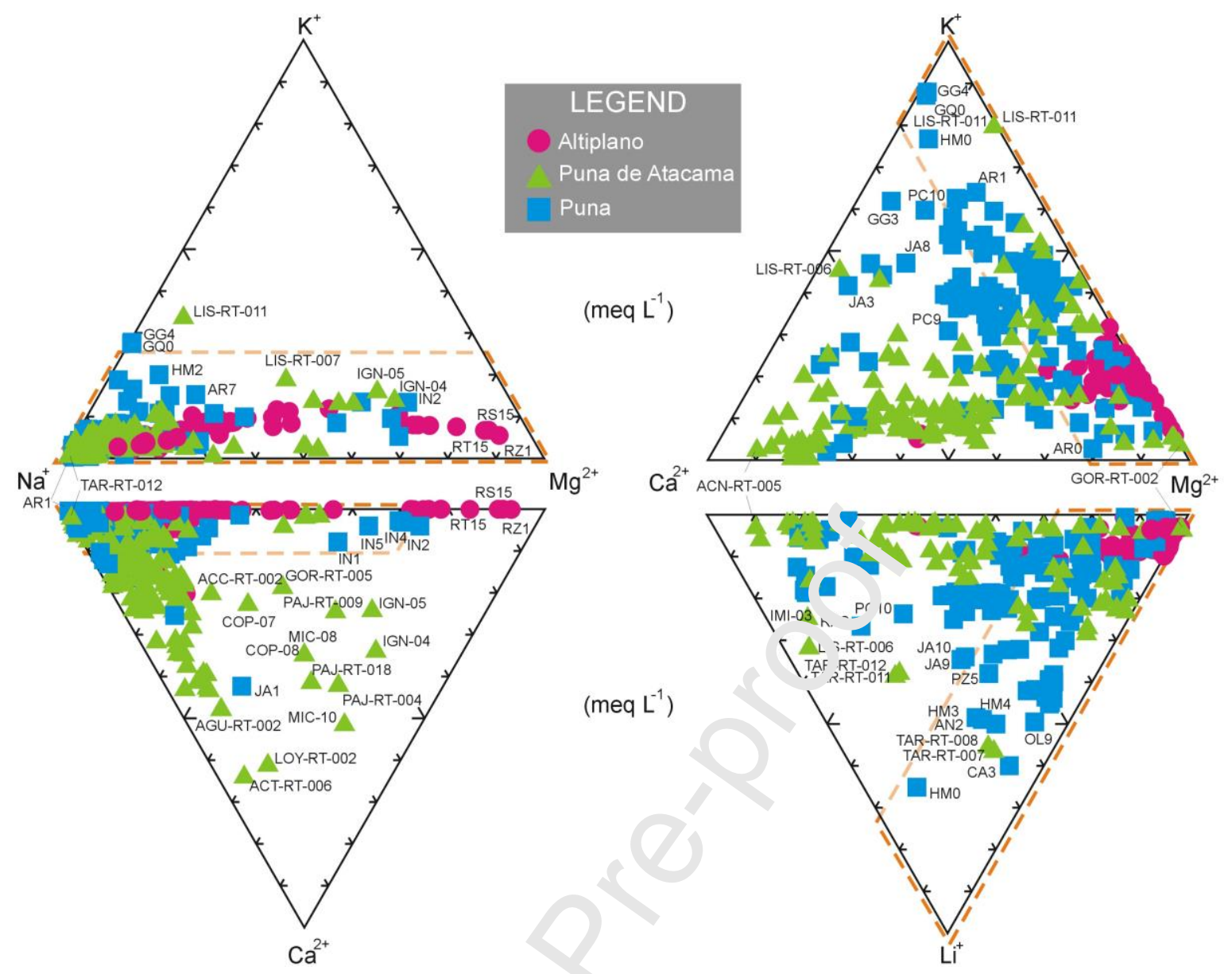

Figure 2. Ternary diagrams displaying relative cationic concentrations measured in brines from Andean salars. Plotted sample a $k^{\prime}$ zoncentrations correspond to those detailed in Table 2. Fields delimited by orange da ' Tibet Plateau (Li et al., 2019b). 

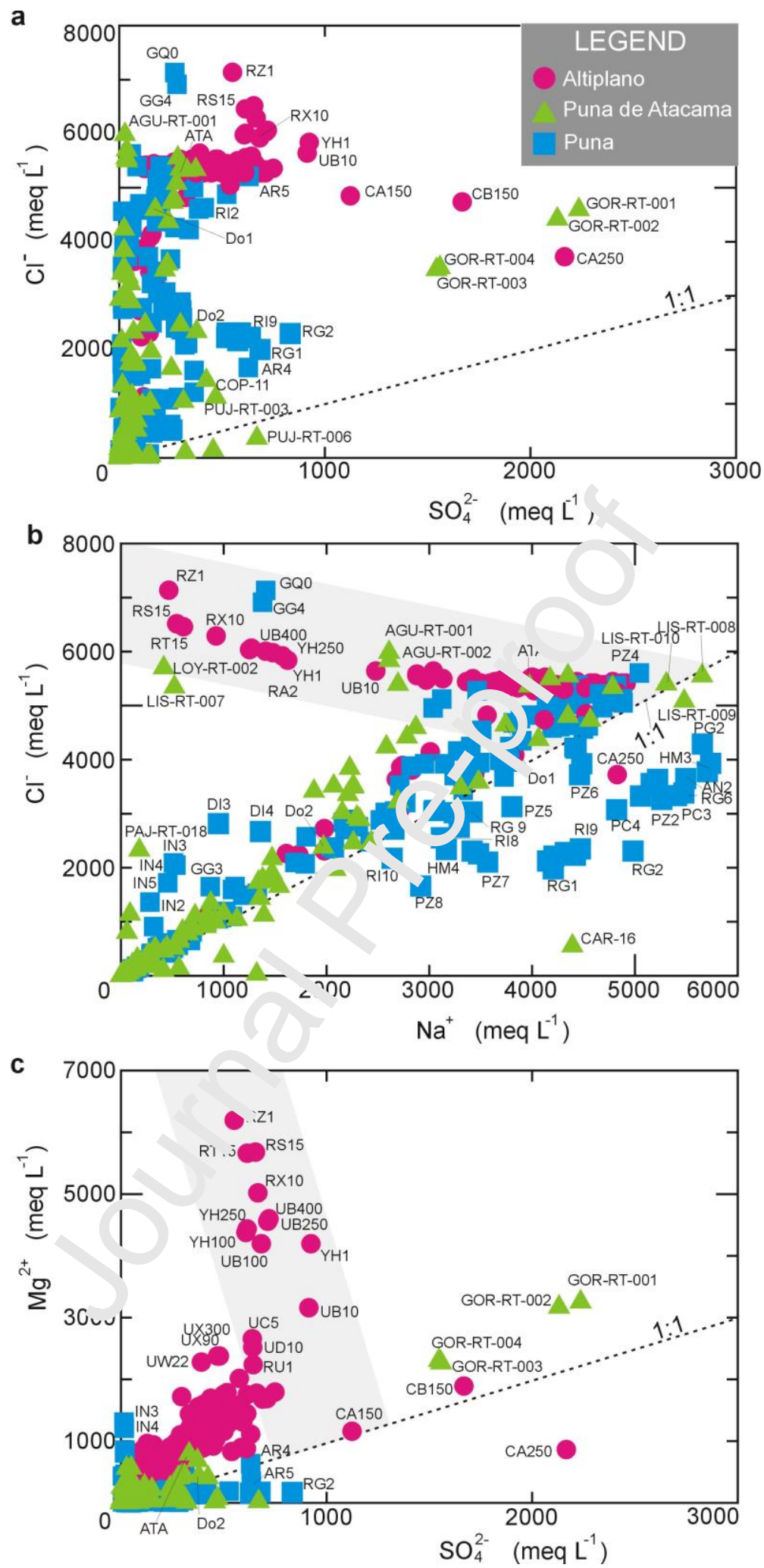

Figure 3. Scatter diagrams plotting the concentrations of a) $\mathrm{SO}_{4}{ }^{2-}$ versus $\mathrm{Cl}^{-}$, b) $\mathrm{Na}^{+}$versus $\mathrm{Cl}^{-}$ , and c) $\mathrm{SO}_{4}{ }^{2-}$ versus $\mathrm{Mg}^{2+}$ in brines from Andean salars. Gray zones in panels a) and b) signal trends that are independent from the 1:1 ratio (dashed line) and that could correspond to brine saturation. Plotted values correspond to concentrations detailed in Table 2. 
The mean $\mathrm{Li}^{+}$concentrations in Empexa and Coipasa are 213 and $258 \mathrm{mg} \mathrm{L}^{-1}$, respectively, whereas the only available sample from Pastos Grandes indicates Li values as high as $1,640 \mathrm{mg} \mathrm{L}^{-1}$ (Ericksen and Salas, 1987). In Uyuni the maximum reported Li value is of 4,720 $\mathrm{mg} \mathrm{L}^{-1}$ with a mean of $715 \mathrm{mg} \mathrm{L}^{-1}$ (Risacher and Fritz, 1991; Tables 2 and 3). Two different tendencies are observed between the concentrations of $\mathrm{Li}^{+}$and $\mathrm{Cl}^{-}$in the Altiplano brines: an oblique trend, which only includes a part of the Uyuni's brines, suggests a positive correlation between $\mathrm{Li}^{+}$and $\mathrm{Cl}^{-}$, whereas a horizontal trend including samples at higher $\mathrm{Li}$ values, shows that the concentrations of $\mathrm{Li}^{+}$in most samples ernlv independently from those of $\mathrm{Cl}^{-}$(Fig. 4 a). Two different tendencies are also observe $i \mathrm{w}^{+}$ween $\mathrm{Li}^{+}$and $\mathrm{Na}^{+}$(Fig. 4 b). A certain amount of data from Uyuni form a roughly pncui-e $\mathrm{Li}^{+}$versus $\mathrm{Na}^{+}$correlation. This trend is consistent with the correlation observed be $w_{\llcorner}^{+} n \mathrm{Li}^{+}$and $\mathrm{Cl}^{-}$, and together suggest that the concentrations of $\mathrm{Li}^{+}$could be re'at $\mathrm{d}$ io the equilibrium solubility of halite. Furthermore, the Pearson's correlati $n$ coefficient (R) corresponding to the mean concentrations of $\mathrm{Li}^{+}, \mathrm{Cl}^{-}$and $\mathrm{Na}^{+}$acru's Andean salars ranges between 0.70 and 0.80 (Fig. 5). The second tendency depicter $b_{\curvearrowright}{ }^{\prime}$ he $\mathrm{Li}^{+}$versus $\mathrm{Na}^{+}$data trend includes most of the Altiplano brine samples, and $\mathrm{f}: \mathrm{rms}$ an oblique line showing $\mathrm{Li}^{+}$increasing inversely to $\mathrm{Na}^{+}$, up to the concentrations of L'vr ni samples RS15 and RZ1 (Figure 4 b). This pattern, which most likely correspon $i^{-}$is brine saturation with respect to halite, suggest that the $\mathrm{Li}^{+}$ concentrations increase while halite precipitates. 

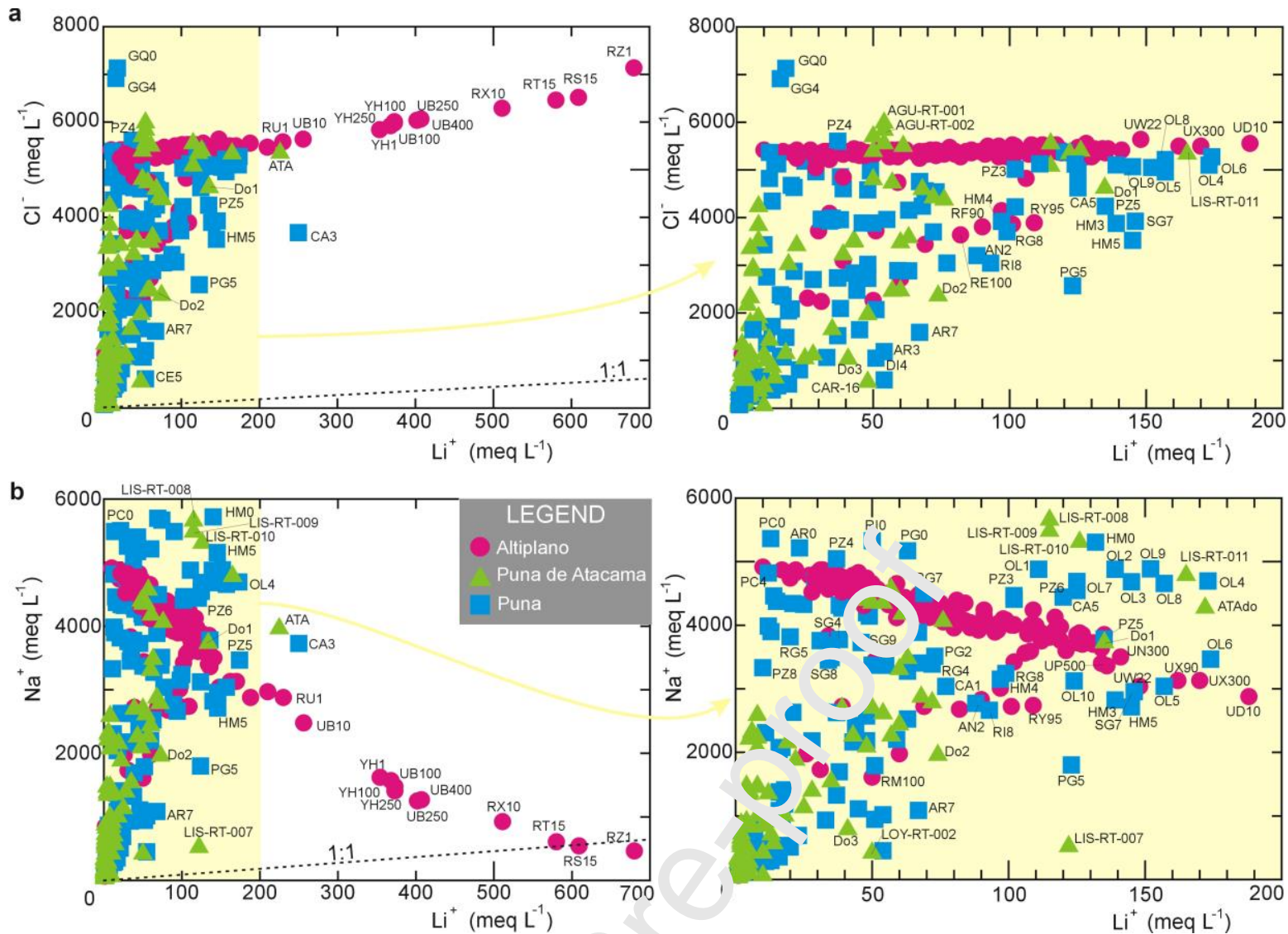

Figure 4. Scatter diagrams showing the $\cdots$ rations of a) $\mathrm{Li}^{+}$versus $\mathrm{Cl}^{-}$, and b) $\mathrm{Li}^{+}$versus $\mathrm{Na}^{+}$, in brines from Andean salars. Insets (yelıuw panels) offer a detailed view of the data displayed in the yellow boxes. Plottea ralues correspond to the concentrations detailed in Table 2. 

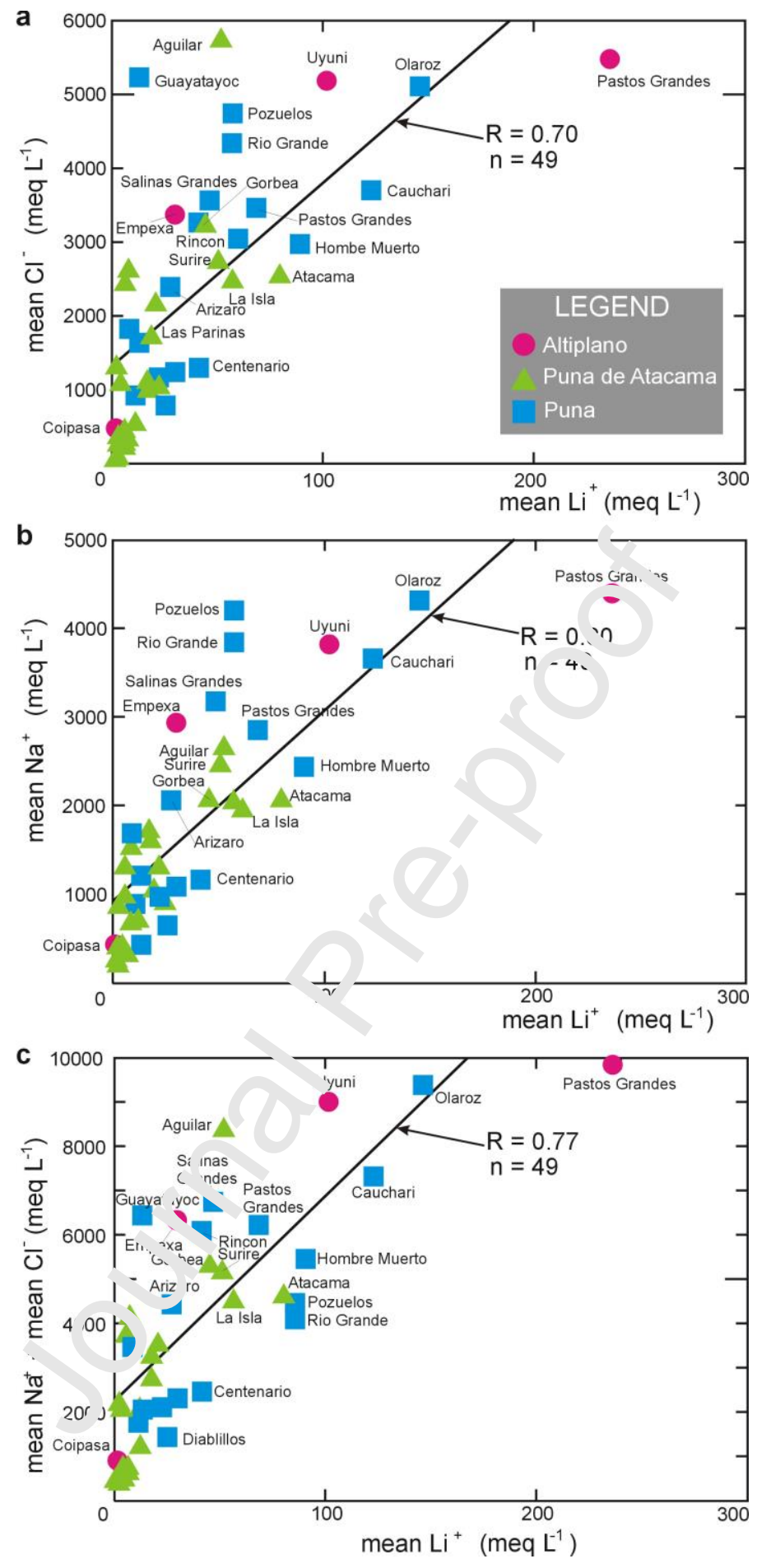

Figure 5. Scatter diagrams plotting the variations for the mean concentrations of a) $\mathrm{Li}^{+}$versus $\mathrm{Cl}^{-}$, b) $\mathrm{Li}^{+}$versus $\mathrm{Na}^{+}$, and c) in $\mathrm{Li}^{+}$versus $\mathrm{Na}^{+}+\mathrm{Cl}^{-}$, in the Andean salars according to values presented in Table 3. The plotted mean $\mathrm{Li}^{+}$concentration for Atacama results from considering values reported by Moraga et al. (1974), Ericksen and Salas (1987), and Rischaer et al. (1999). It is important to note that this value differ from the globally accepted mean $\mathrm{Li}$ concentration in Atacama that is $1,400 \mathrm{mg} \mathrm{L}^{-1}$ ( $202 \mathrm{meq} \mathrm{L}{ }^{-1}$; Moraga et al., 1974; Ide and Kunasz, 1989; Kunasz, 2006). $\mathrm{R}$ is the Pearson correlation coefficient, $\mathrm{n}$ is the total number of points in the data set (i.e., the number of salars). 
An additional interesting feature of the Altiplano brines is that $\mathrm{Li}^{+}$also seems to correlate, in different proportions, with $\mathrm{K}^{+}, \mathrm{B}$, and $\mathrm{Mg}^{2+}$ (Fig. 6). The $\mathrm{K}^{+}: \mathrm{Li}^{+}$ratios in most Altiplano brines array along a 1:4 trending line, a pattern that could be consistent with the equilibrium solubility of 1:4 salts (complex K-, Li-, Na- $\mathrm{Cl}$ salts, yet undetermined). Samples plotting along an oblique trend to the 1:4 proportion suggest saturation of the brine with respect to these compound (Fig. 6 a). When comparing mean values, it can be observed that the correlation $\mathrm{R}$ between $\mathrm{Li}^{+}$and $\mathrm{K}^{+}$reaches 0.68 , which confirms this pattern reflects a $\mathrm{Li}^{+}$$\mathrm{K}^{+}$interdependency (Fig. 6 b).

The concentrations of $\mathrm{Li}^{+}$and $\mathrm{B}$ in the Altiplano b ill plot along a line that defines a 3:1 proportion trend (Fig. $6 \mathrm{c}$ ), and mean values are hiohly correlated $(\mathrm{R}=0.78$; Fig. 6 d). The concentrations of $\mathrm{Li}^{+}$also increase consistently with those of $\mathrm{Mg}^{2+}$ (Fig. 6 e), with the $\mathrm{Mg}^{2+}: \mathrm{Li}^{+}$ratios defining trends with correlati on. $\mathrm{o}^{+}$about 1:50 in Coipasa, 1:13 in Empexa and Uyuni, and $\sim 1: 1$ in Pastos Grandes (.ig 6 e). The observed proportionalities between $\mathrm{Li}^{+}$, $\mathrm{B}$ and $\mathrm{Mg}^{2+}$ have not been yet explaine.' and could correspond to the equilibrium solubility of complex borates and other salt or, Iternatively, to the ionic influence of cations in exchangeable positions withi. clays. In any case, these proportionalities require further investigations. Interestinglv, he $\mathrm{Li}^{+}$versus $\mathrm{B}$ pattern defined by the Altplano brines is close to that displayed by brine trun saline lakes in the Tibet Plateau (Fig. 6 c), which contains the second most important Li-brine type deposits on Earth (Zheng and Liu, 2009; Kesler et al., 2012; Li et al., 2019b, and references therein).

Mean Mg:Li ratios are 22 in Uyuni, 40 and 47 in the Empexa and Coipasa, respectively, and as low as 2 in Pastos Grandes (Fig. 6 C, Table 4). With $\mathrm{Mg}^{2+}$ means of $>15,000$ and $>12,000 \mathrm{mg} \mathrm{L}^{-1}$, the Uyuni and Coipasa brines contain amongst the highest magnesium concentrations in the Andean plateau (Figs. 2 and 5 e, Tables 3 and 4). 

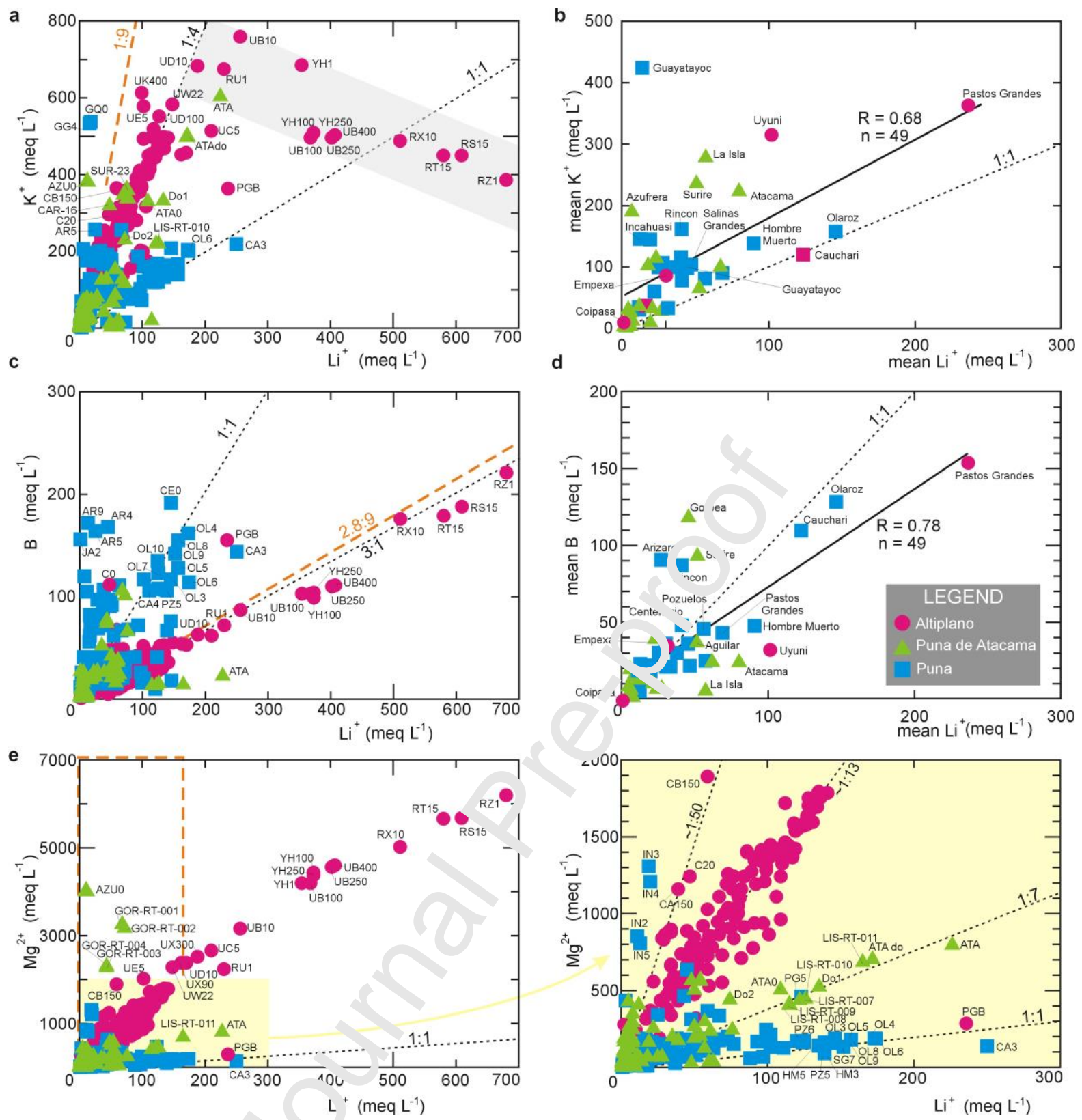

Figure 6. Scatter diagram, showing the variation between the concentrations of a) $\mathrm{Li}^{+}$and $\mathrm{K}^{+}$, b) mean $\mathrm{Li}^{+}$and mean $\mathrm{K}^{r}$, c) $\mathrm{Li}^{+}$and $\mathrm{B}, \mathrm{d}$ ) mean $\mathrm{Li}^{+}$and mean $\mathrm{B}$, and e) $\mathrm{Li}^{+}$and $\mathrm{Mg}^{2+}$. Values plotted in a), c), and e) are for brine compositions presented in Table 2. Scatter diagrams b) and d) plot mean concentrations according to values summarized in Table 3. Continuous line: $\mathrm{R}$ correlation coefficient, with $\mathrm{n}=$ the total number of salars. Dashed line: stoichiometric ratio. Orange dashed line and rectangle: stoichiometric proportions (panels a and c) and field (panel e) characterizing brines from the Tibetan Plateau (data from Li et al., 2019b).

\subsection{Puna de Atacama Salars}

Salt pans in the Puna de Atacama are located at altitudes between 2,300 (Atacama) and 4,500 (Pujsa, \#15) $\mathrm{m}$ asl (Table 1, Fig. 1). The surfaces of these salars and their endorheic 
basins are highly variable. With its $3,000 \mathrm{~km}^{2}$, Atacama is the largest Chilean salt pan and, with a catchment area of $18,100 \mathrm{~km}^{2}$, also the largest endorheic basin in the Chilean portion of the plateau. The smallest salt pans, such as Salar de la Laguna (\#35) and Ignorados (\#27), are only of $1 \mathrm{~km}^{2}$ (Table 1). In the Puna de Atacama, only the Salar de Atacama is presently being mined for Li.

The brine chemistry of salars in the Puna de Atacama was comprehensively addressed by Risacher et al. (1999). Brines have highly variable salinity, with TDS ranging up to $370 \mathrm{~g}$ $\mathrm{L}^{-1}$. The highest salt concentrations are observed in brines from Su -ire (\#1), Atacama, and La Azufrera (\#25), where mean values grade between 178 and $\angle \iota^{7} \mathrm{~g} \mathrm{~L}^{-1}$ (Tables 2 and 3).

According to their major chemical compositions, the Puna de Atacama brines are of the $\mathrm{Na}^{+}-\mathrm{Mg}^{2+} / \mathrm{Cl}^{-}-\mathrm{SO}_{4}{ }^{2-}$ type (Figs. 2 and 3 a). A - ew brines contain $\mathrm{Mg}^{2+} \geq \mathrm{Na}^{+}$(e.g., samples IGN-04 and 05, PAJ-RT-004 and 018, ‘ C -RT-006; Fig. 2), and/or $\mathrm{Ca}^{2+} \geq \mathrm{Na}^{+}$and $\mathrm{Mg}^{2+}$ (e.g., samples ACT-RT-006, LO:-R'-002, MIC-10, and AGU-RT-002; Fig. 2). The concentrations of $\mathrm{Cl}^{-}$are generally $\mathrm{h}_{\mathrm{c}}$ - her than those of $\mathrm{SO}_{4}{ }^{2-}$, with few samples of low salinity having $\mathrm{SO}_{4}{ }^{2-}>\mathrm{Cl}^{-}$(e.g., samp ar PUJ-RT-006 to 008, ACSS-RT-005 to 007, IGN-004 and 005; Fig 3 a). The main $c^{\prime}$ aracieristics of salar brines in the Puna de Atacama are their high $\mathrm{Ca}^{2+}$ and their relatively $1 \mathrm{~N} \mathrm{~K}^{+}$when compared to brines from neighboring parts of the plateau (Fig. 2).

The $\mathrm{Na}^{+}$versus $\mathrm{Cl}^{-}$concentration patterns are quite similar to those observed in the Altiplano brines (Fig. 3 b). Stoichiometric ratios $\sim 1: 1$ between $\mathrm{Na}^{+}$and $\mathrm{Cl}^{-}$are consistent with the equilibrium solubility of halite $(\mathrm{SI} \approx 0$, e.g., sample Do2; Fig. 3 b), and samples plotting oblique to the 1:1 proportion trend suggest brine halite saturation and precipitation (SI $>0$ and up to 0.47, e.g., samples AGU-RT-001, LOY-RT-002, LIS-RT-007; Fig. 3 b). Similarly to the Altiplano brines, the $\mathrm{SO}_{4}{ }^{2-}$ and $\mathrm{Mg}^{2+}$ concentrations plot along the 1:1 proportional line, which is consistent with the equilibrium solubility of epsomite $\left(\mathrm{MgSO}_{4} 7 \mathrm{H}_{2} \mathrm{O}\right)$, and/or other 
Mg-bearing sulfates (Fig. 3 c). However, some brines do not match the $\mathrm{SO}_{4}{ }^{2-}: \mathrm{Mg}^{2+}$ uniequivalent proportion trend, which implies the presence of other salts that are not in equilibrium with the brines (e.g., SI maxima for anhydrite and gypsum reach values of 1.07 and 1.10, respectively, in sample AGU-RT-001).

Li concentration in pan brines of the Puna de Atacama are very high. Indeed, the Puna de Atacama desert is known as having the richest Li brine-type deposits on Earth, and the salt pan of Atacama is the most important operating Li mine in world today, with mean Li grades of 1,400 $\mathrm{m} \mathrm{L}^{-1}$ and maximum measured concentrations reachino $\mathrm{c}, 100 \mathrm{mg} \mathrm{L}^{-1}$ (Moraga et al., 1974; Ide and Kunasz, 1989; Kunasz, 2006). Other than $\mathrm{A}^{7}{ }^{7}$ cama, high $\mathrm{Li}^{+}$concentrations were also measured, for instance, in La Isla (\#30), Gorhe. (\#26), and Surire, where mean $\mathrm{Li}^{+}$ grades are between 300 and $400 \mathrm{mg} \mathrm{L}^{-1}$ (Tables 2 and 's,

Despite that the $\mathrm{Li}^{+}$versus $\mathrm{Cl}^{-}$and $\mathrm{Na}^{\top}$ cr.centrations distribute quite dispersedly, samples plot within the field defined by tre ds of the Altiplano brines (Fig. 4). Furthermore, mean $\mathrm{Li}^{+}, \mathrm{Cl}^{-}$and $\mathrm{Na}^{+}$concentrations i.nm the Puna de Atacama salars match the correlation lines characterizing other Andean tri.es (Fig. 5). Positive correlations could also exist between the concentrations of $\mathrm{i}^{+}$and $\mathrm{K}^{+}$(Figs. 6 a and b). However, no evident correlation is observed between $\mathrm{Li}^{+}$and $\mathrm{L}$ (Figs. $6 \mathrm{c}$ and d), whereas some samples arrays along the 1:7 proportional line, whicı mınt imply the existence of complex $\mathrm{Li}, \mathrm{Mg}$ bearing salts (Fig. 6 e).

Despite that nearly uniequivalent proportions of $\mathrm{Mg}$ and $\mathrm{Li}$ are found in El Tara (\#13) and Imilac (\#21), these ratios are most often $\neq 1 . \mathrm{Mg}^{2+}: \mathrm{Li}^{+}$ratios $<10$ are observed in Pujsa, Loyoques (\#16), La Isla, Las Parinas (\#32), Surire, Maricunga (\#38), and Atacama, whereas brines with $\mathrm{Mg}^{2+}$ concentrations about two orders of magnitude higher than those of $\mathrm{Li}^{+}$are found in Michincha (\#7), Ignorados, and La Azufrera (Fig. 6 e, Table 4). This kind of brines, characterized by $\mathrm{Mg}^{2+} \gg \mathrm{Li}^{+}$, are also observed in brines from saline lakes in the Tibet Plateau (Fig. 6 e; Li et al., 2019b). 


\subsection{Puna Salars}

The Puna plateau holds 17 major salars that are located at altitudes ranging between 3,269 (Incahuasi, \#39) and 4,080 (Jama, \#53) m asl (Table 1; Fig. 1). With the exception of giant Arizaro $\left(1,708 \mathrm{~km}^{2}, \# 42\right)$ and the three smallest salars sizing less than $10 \mathrm{~km}^{2}$ (Centenario, Diablillos, \#44, and Ratones), salt pans surfaces range from 30 to $650 \mathrm{~km}^{2}$ (Table 1). These salars are settled in endorheic basins with surfaces that mostly vary from 1,000 to $9,000 \mathrm{~km}^{2}$. With $14,536 \mathrm{~km}^{2}$, Rio Grande (\#41) holds :e largest basin catchment area, whereas the smallest basins correspond to the smalles ‘ sa't pans (Table 1).

Amongst the Puna salt pans, only Hombre Mu to and Olaroz are being actively mined for Li. The brine chemistry in the Puna sala: $`$ has been characterized by López Steinmetz et al. (2018) and López Steinmetz . . (2020a). These brines contain highly variable saline content and ionic proport. $\mathrm{n} r$. TDS as low as $6 \mathrm{~g} \mathrm{~L}^{-1}$ have been found in some salars such as Jama, whereas TDS up « $381 \mathrm{~g} \mathrm{~L}^{-1}$ were found at Olaroz, define the maximum measured values (García et al., 2019). F, rines from the Puna salars are of the $\mathrm{Na}^{+}-\mathrm{K}^{+} / \mathrm{Cl}^{-}-$ $\mathrm{SO}_{4}{ }^{2-}$ type in the north, of $\mathrm{th}_{1} \mathrm{Na}^{+}-\mathrm{Mg}^{2+} / \mathrm{Cl}^{-}-\mathrm{SO}_{4}{ }^{2-}$ type in the south, and the $\mathrm{SO}_{4}{ }^{2-}$ concentrations increase from $?$ th to north (Figs. 2 and 3 a).

Similar to the $\mathrm{A}^{-}$iDıano and Puna de Atacama, most of the Puna brines have $\mathrm{Na}$ and $\mathrm{Cl}$ concentrations that correlate positively along a 1:1 stoichiometric ratio, which is consistent with equilibrium solubility of halite (SI $\approx 0$, e.g., samples AR9, PC7; Fig. 3 b). Some degree of correlation could exit between $\mathrm{SO}_{4}{ }^{2-}$ and $\mathrm{Mg}^{2+}$ in some samples such as AR4 and AR5. However, as depicted in Figure $3 \mathrm{c}$, the $\mathrm{Mg}^{2+}: \mathrm{SO}_{4}{ }^{2-}$ ratios do not match the $1: 1$ trend, implying the existence of other $\mathrm{Mg}^{2+}$ - and $\mathrm{SO}_{4}{ }^{2-}$-bearing salts (e.g., maximum SI values for anhydrite and gypsum range from -3.19 to 0.54 and -2.95 to 0.63 , respectively, in samples IN3 and RG2). 
Amongst Puna salars, maximum $\mathrm{Li}^{+}$values of 1,739 and $1,213 \mathrm{mg} \mathrm{L}^{-1}$ were found in Cauchari and Olaroz, respectively (Tables 2 and 4). In addition to these salt pans, where mean Li concentrations reach 860 and $841 \mathrm{mg} \mathrm{L}^{-1}$, respectively, high Li-graded brines are stored in Hombre Muerto, Pastos Grandes (\#49), Pozuelos (\#48), Rio Grande, Salinas Grandes, and Rincon (\#50), where mean $\mathrm{Li}^{+}$concentrations are between 280 and $570 \mathrm{mg} \mathrm{L}^{-1}$ (Table 3).

According to its geochemical behavior, $\mathrm{Li}$ variations in brines are expected to be consistent with those of other conservative solutes such as $\mathrm{Cl}^{-}$and $\mathrm{Na}^{+}$. Positive correlations can exist between the concentrations of $\mathrm{Li}^{+}, \mathrm{Cl}^{-}$and $\mathrm{Na}^{+}$in su. ne cases (Figs. 4 and 5). Furthermore, $\mathrm{Li}$ also seems correlate positively with $\mathrm{K}^{+}$an $\mathrm{iL}$, and to a minor extent also with $\mathrm{Mg}^{2+}$ (Fig. 6). Interestingly, the concentrations of $\mathrm{Li}^{+}$ana $\mathrm{Y}^{+}$in the Olaroz and Cauchari (\#51) brines display along the 1:1 ratio, whereas proportirns $n$ the remaining brines better fit the 1:4 dominant pattern defined by the Uyuni' $\iota$ in s (Figs. 6 a). Despite there is no clear pattern between $\mathrm{Li}^{+}: \mathrm{B}$ and $\mathrm{Li}^{+}: \mathrm{Mg}^{2+}$, nea ${ }^{-l} \mathrm{~V}$-quivalent proportions are mainly observed in salt pans from the northern Puna (Figs. 6, $\mathrm{d}$ and e). However, brines from the Southern Puna instead show ionic proportional $\boldsymbol{r n t t e}^{n} \boldsymbol{n}$, mainly displaying parallel to the vertical axis (i.e., parallel to the $\mathrm{B}$ and $\mathrm{Mg}^{2+}$ ax $)$, such as for Incahuasi, which brines match the trend $\sim 1: 50$ ratio of the Coipasa brines $(1:$ r 5 e).

With the excepinn of Incahuasi, which brines contain high $\mathrm{Mg}^{2+}$ concentrations that are in the range of those observed in Uyuni and Coipasa (Fig. 6 e), remaining Puna salt pans, especially in the northern Puna, show the lowest $\mathrm{Mg}^{2+}$ values amongst the entire Andean plateau (Fig. 2, Table 4). These salars are characterized by brines having mean Mg:Li ratios $\leq$ 11, and some brines have exceptionally low ratios of 1 to 3 , as the case of Ratones, Guayatayoc, Cauchari, and Olaroz (Table 4).

\section{Discussion}




\subsection{Lack of Li geographical distribution}

Andean Li-brine type deposits are found both in mature and in immature salars (Houston et al., 2011; Fig. 7 a and b). Andean mature salars, such as Atacama, correspond to halite dominated pans, whereas immature salars, like Uyuni and Olaroz, are mostly filled by clastic saline muds (Houston et al., 2011). Sometimes, mature and immature zones can be found in the same salt pan. For example, western Hombre Muerto corresponds to a mature pan, whereas its eastern side is an immature salar. An additinna example is the Salar de Atacama. Here, the halite nucleus (i.e., mature salar) $\mathrm{spr}$ aci tor an area of $1,100 \mathrm{~km}^{2}$ and $\sim 1,000 \mathrm{~m}$ depth, in the southern part of the salar w:ereas the northern part is clastic dominated and gypsum rich (Boutt et al. 2016; Corentha. et al. 2016; and references therein).

However, the more often, Andean salt p ns are complex combinations of crystalline salt layers, which are interbedded, in hig. ${ }^{-1} \mathrm{y}$.nd variable proportions, with clastic fine -graded sequences (e.g., Salar del Rincon ani Maricunga). In the practice, the predominant type tendency of a salt pan is revealer th r.lore clearly during the brine extraction. Pumping in mature and immature pans imץ icates different responses of the water (i.e., brine) table due to the contrasting porosity (a.d permeability) of the substrate (i.e., porous salt pan and impermeable clay and ruuy -rich deposits, respectively). During operations, pumping in a mature salar conduces to the development of a shallow depression cone of the water table around the pumping well, whereas in immature salars the cone deepens faster than it extends horizontally (Houston et al., 2011).

Three major noteworthy observations need to be addressed concerning mature and immature salars. Firstly, there is no strict rule and the areal extent of mature salars does not necessarily exceed that of immature salars (see Table 1). Secondly, brines in halite-dominated pans does not always contain higher Li concentrations than immature salars (Houston et al., 
2011; see Table 3). Thirdly, high Li -graded brines are not necessarily related to saline nucleus. Furthermore, deeper brines are not systematically richer in lithium. For instance, in the salt pan of Atacama the Li concentration isopleths form a pattern consisting of concentric Li grade zones with maximum values located in the southern part - and not in middle - of the halite nucleus (Moraga et al. 1974; Stoertz and Ericksen 1974; Ide and Kunasz 1989; Bevacqua 1992; Alonso and Risacher 1996; Carmona et al. 2000; Boschetti et al. 2007; Boutt et al. 2016; Corenthal et al. 2016). These concentric patterns are not the same at near surface levels as they are at depth. For example, if it is true that in the IJ y ni salar Li concentrations increase concentrically and asymmetrically with depth, mc vit.? southward (Risacher and Fritz 1991; Fig. 7 c), in certain parts, Li concentrations do nnt change with depth, such as along the UI well where a constant $\mathrm{Li}$ concentration $\left(300 \mathrm{mg} \mathrm{I}^{-1}\right.$ ) : s reported from near surface down to $10 \mathrm{~m}$ depth (Fig. 7 c). An additional example $\jmath_{1}$ hi, is the Salar de Olaroz. The highest near surface concentrations of Li occur formi. $\sigma$ \% pattern that can be followed along a NE-SW axis running through the middle of the salaı 'García et al., 2020; Fig. 7 d). Conversely, the pattern at $200 \mathrm{~m}$ depth consists of two hioh $\mathrm{I}$ : level zones in the northern and southern parts of the salar, disrupted by an intermec: ate urine grade zone near the center of the pond (see García et al., 2020; Fig. 7 e).

Aridity is an in ${ }_{\iota_{1}}$ (o เant parameter controlling brine Li concentration along a vertical profile. By enhancing evaporation near the surface, it can cause shallower brines to have higher Li levels than those lying below. Clearly, a complex interplay of the above aspects to which add other factors such as the presence of hydrothermal springs and the role played by structures on Li-rich waters supply into the system, among many others listed by Godfrey et al. (2013; cf. also discussion below, sections 5.4 and 5.5), drive the singularity of each Andean salar. This notwithstanding, it is remarkable to observe that the major hydrochemical composition of brines is relatively similar across the Andean plateau (Fig. 8). 

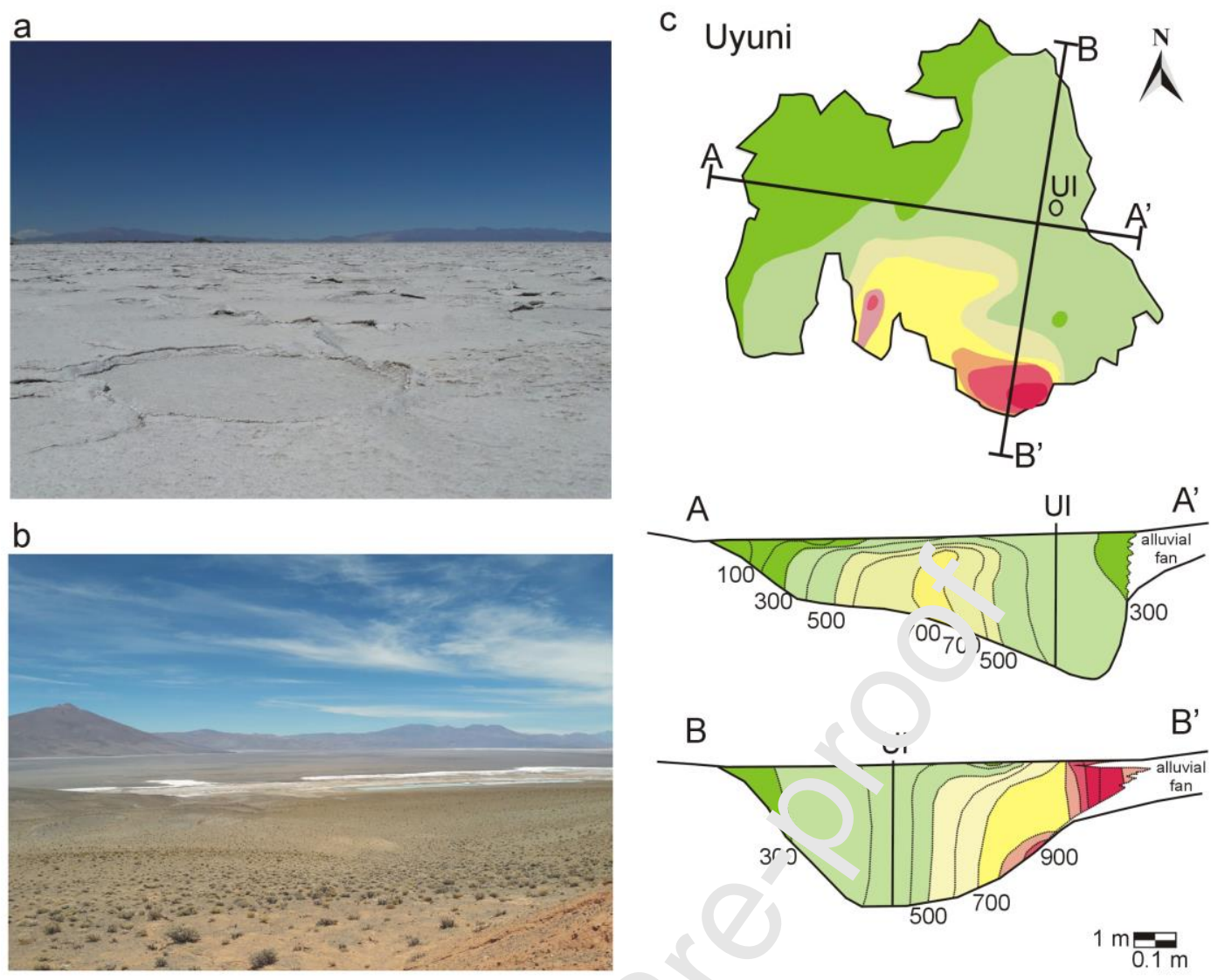

d

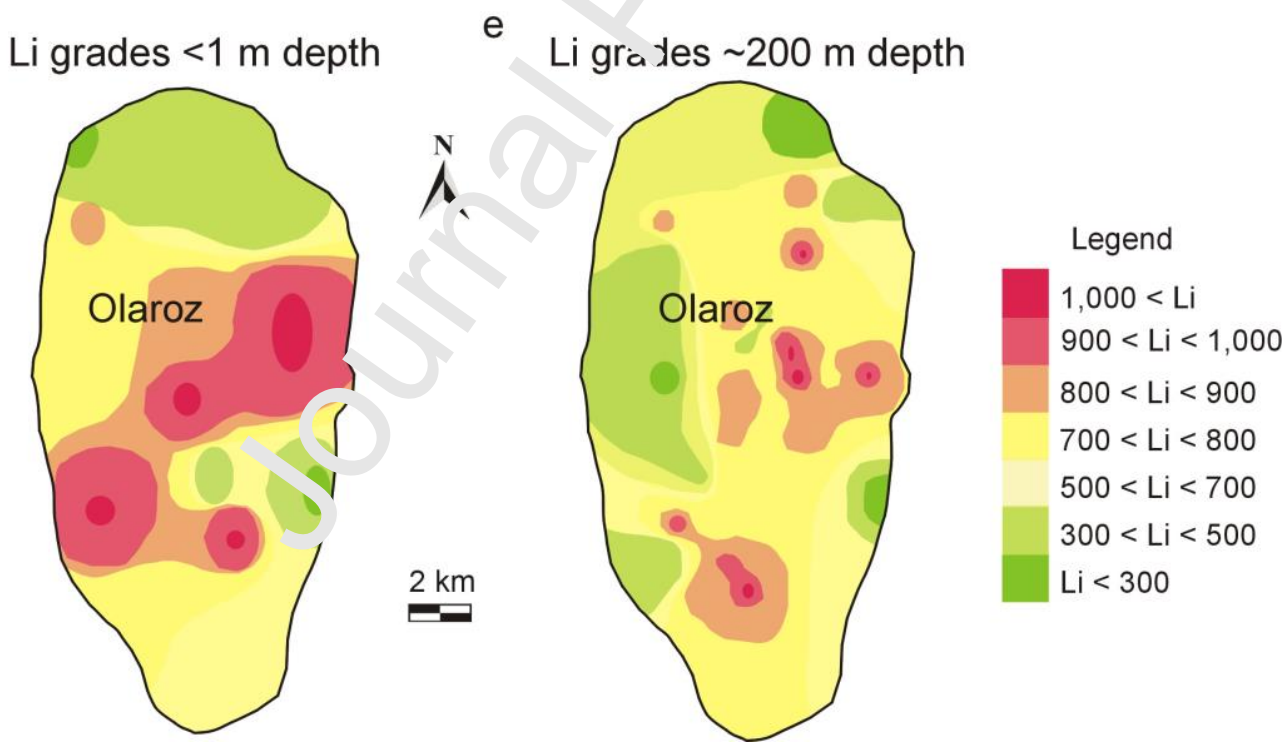

Figure 7. Pictures showing a) Salar de Pastos Grandes (Puna), and b) Salar del Rincón, respectively examples of mature and immature Andean salars. Notice the salt crust and the brown clastic surfaces. c) Map (upper panel) showing the $\mathrm{Li}$ isoconcentration curves in brines and the location of vertical profiles A-A' (middle panel) and B-B' (bottom panel) from Uyuni (modified from Risacher and Fritz, 1991). The location of well UI (referred in the text of section 5.1) is shown in panels. $\mathrm{d}$ and e) Map showing the concentration of $\mathrm{Li}$ in near surface ( $<1 \mathrm{~m}$ depth) and deep ( $200 \mathrm{~m}$ depth) brines in Salar de Olaroz (modified from Garcia et al., 2020). Li concentrations are in $\mathrm{mg} \mathrm{L}^{-1}$. 
A typical feature of evolved (evaporated) and highly saline waters is a composition marked by the presence of $\mathrm{Cl}^{-}$and $\mathrm{SO}_{4}{ }^{2-}$, and a depletion in $\mathrm{CO}_{3}{ }^{2-} / \mathrm{HCO}_{3}{ }^{-}$(Langbein, 1961; Hardie and Eugster, 1970; Eugster, 1980). Andean brines can be compared to those from Libearing saline lakes in the Tibetan Plateau ( $\mathrm{Li}$ et al., 2019b, and references therein), despite obvious geological-environmental differences. In both cases, they commonly belong to the $\mathrm{Cl}^{-}$ - $\mathrm{SO}_{4}{ }^{2-}$ type, and the hydrochemical variability is generally marked by variations in the major cations (Figs. 2 and 3 a). Our data compilation indicates that composition with a $\mathrm{Na}^{+}-\mathrm{Mg}^{2+}$ signature largely predominate in the whole Andean plateau (and in Tibet), with the exceptions of Uyuni $\left(\mathrm{Mg}^{2+}-\mathrm{Na}^{+}\right.$signature) and the Northern Puna sal rs $\left(\mathrm{Na}^{+}-\mathrm{K}^{+}\right.$signature). Brines with high $\mathrm{Mg}^{2+}$ concentrations occur in the Altiplano. wh reas they are generally depleted in this cation in the Northern Puna. Finally, $\mathrm{Ca}^{2+}$ shows the nighest concentrations in the Puna de Atacama, west of the modern Andean volcanic a. (Tig. 8).

The association between Li and $\mathrm{L}$ ev denced by our data (Figs. $6 \mathrm{c}$ and $\mathrm{d}$ ) confirms the

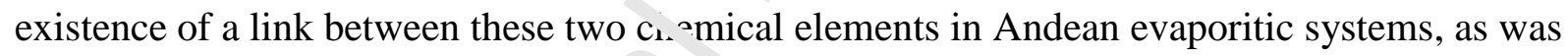
indicated by Catalano (1964), Alnnso et al. (1988), Alonso et al. (1991), Kistler and Helvaci (1994), and observed in other sarts of the globe (e.g., Helvaci et al., 2004, and references therein). However, isotopic ${ }^{+}$lies have shown that, in the Andes, Li and B share only a partial common origin ("ascman et al., 2004). Two distinctive origins have been suggested as sources for boron: for the western plateau, isotopic values indicate a volcanic contribution, mostly Neogene meso-silicic pyroclastic rocks and related hydrothermal systems, whereas weathering of volcanoclastic sequences from the Paleozoic basement are the probable source of B in the eastern plateau (Kaseman et al., 2004). The Paleozoic basement is also considered to be the primary source of Li (Egenhoff and Lucassen, 2003; Peralta Arnold et al., 2017; García et al., 2019; Meixner et al., 2019). Such common origin is reflected by the strong association between $\mathrm{Li}$ and $\mathrm{B}(\mathrm{R}=0.78$; Fig. 6 d). However, their concentration ratios grading 
up to $3: 1$, and the fact that they are mostly characterized by $\mathrm{Li}>\mathrm{B}$ south of $\sim 22^{\circ} \mathrm{S}$ and $\mathrm{B}>\mathrm{Li}$ to the north of it, point to the absence of unambiguous $\mathrm{Li}: \mathrm{B}$ patterns, consistently with $\mathrm{B}$ and $\mathrm{Li}$ being sourced from different lithologies. While it appears clear that further studies on the Li-B geochemical relationships are necessary (e.g., Lopez Steinmetz et al., 2020a), it seems safe to suggest that B may not be an appropriate prospective tool for lithium, at least not in the Andean region.

Despite that major brine chemistry, as discussed above, shows some degree of geographical organization with respect to compositions (Fir $\gamma$, there is no obvious $\mathrm{Li}^{+}$ distribution across the Andean plateau. Geographic patter $₫$ s re also not observed for K, B, and $\mathrm{Mg}$. The only common trend shown by those plnts is that, as a whole, maximum $\mathrm{Li}^{+}$ values were reported from salt pans located in the ceatı.' area of the plateau, between $66^{\circ} 30^{\prime}$ $-68^{\circ} 30^{\prime} \mathrm{W}$ and $20^{\circ}-24^{\circ} \mathrm{S}$ (Figs. 9 a and b) ' $1^{\prime}$.is spatial distribution is consistent with that of other cations, such as $\mathrm{Mg}^{2+}$ (Figs. $9 \cdot \mathrm{a}^{\mathrm{r}} \mathrm{d} \mathrm{d}$ ), confirming that the most saline brines and highest ionic concentrations occur in $h^{-}$middle of the Andean plateau desert. It would thus be expected that solute concentratinn: vould decrease in salt pans located towards the desert borders. This pattern is intris ing and clearly worthy of further studies. In summary, Li concentrations across the $A_{\iota}$ de in plateau lack a clear geographic distribution pattern, other than that depicted in $\mathrm{Fl}_{5}$ 'rte $y$. 


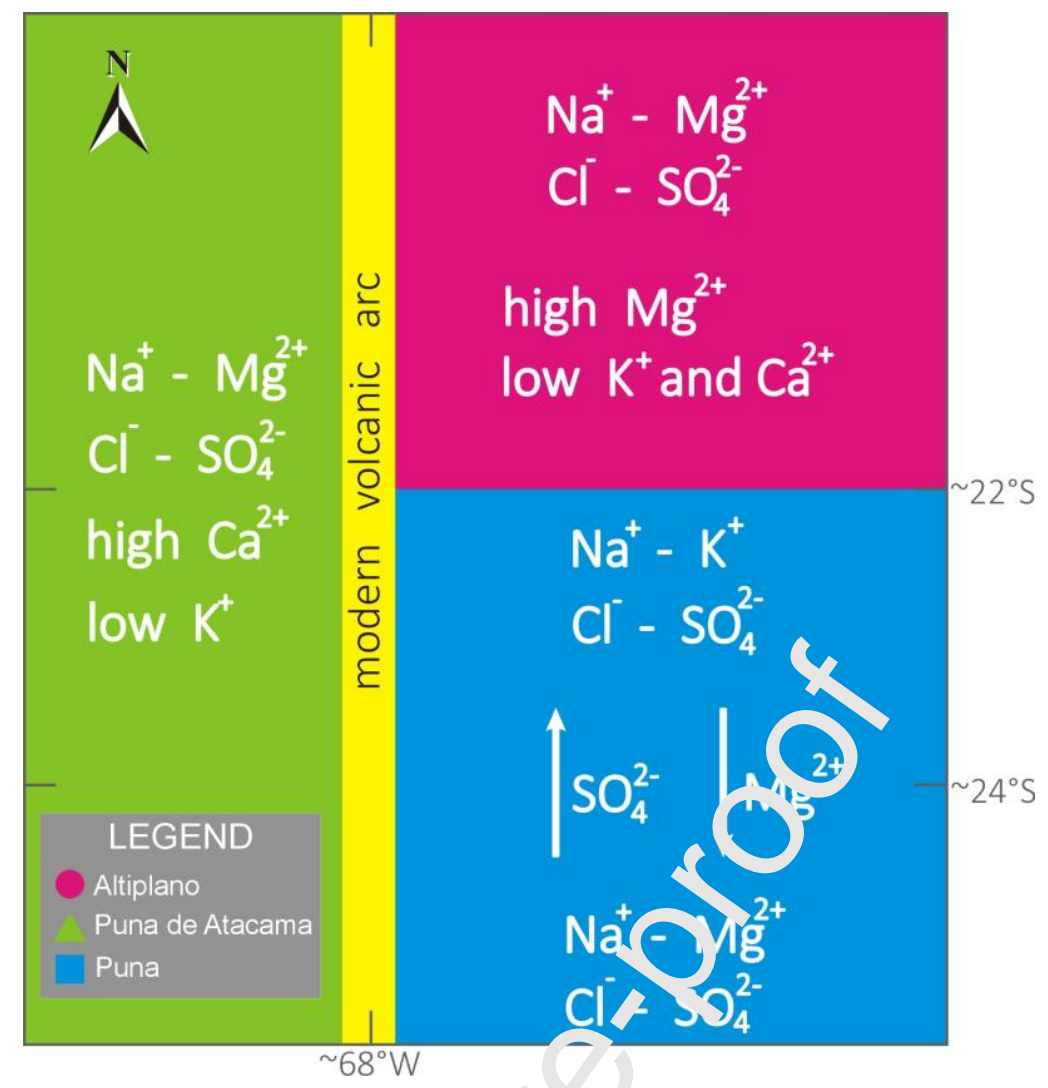

Figure 8. A schematic illustration of th ntenal subdivision of the Andean plateau (see legend), summarizing major brine cht. ni, try in salt pans across the Lithium Crescent. "Modern volcanic arc" (yellow area) refers to the present-day situation; the past Cenozoic situation is not considered in this schem 

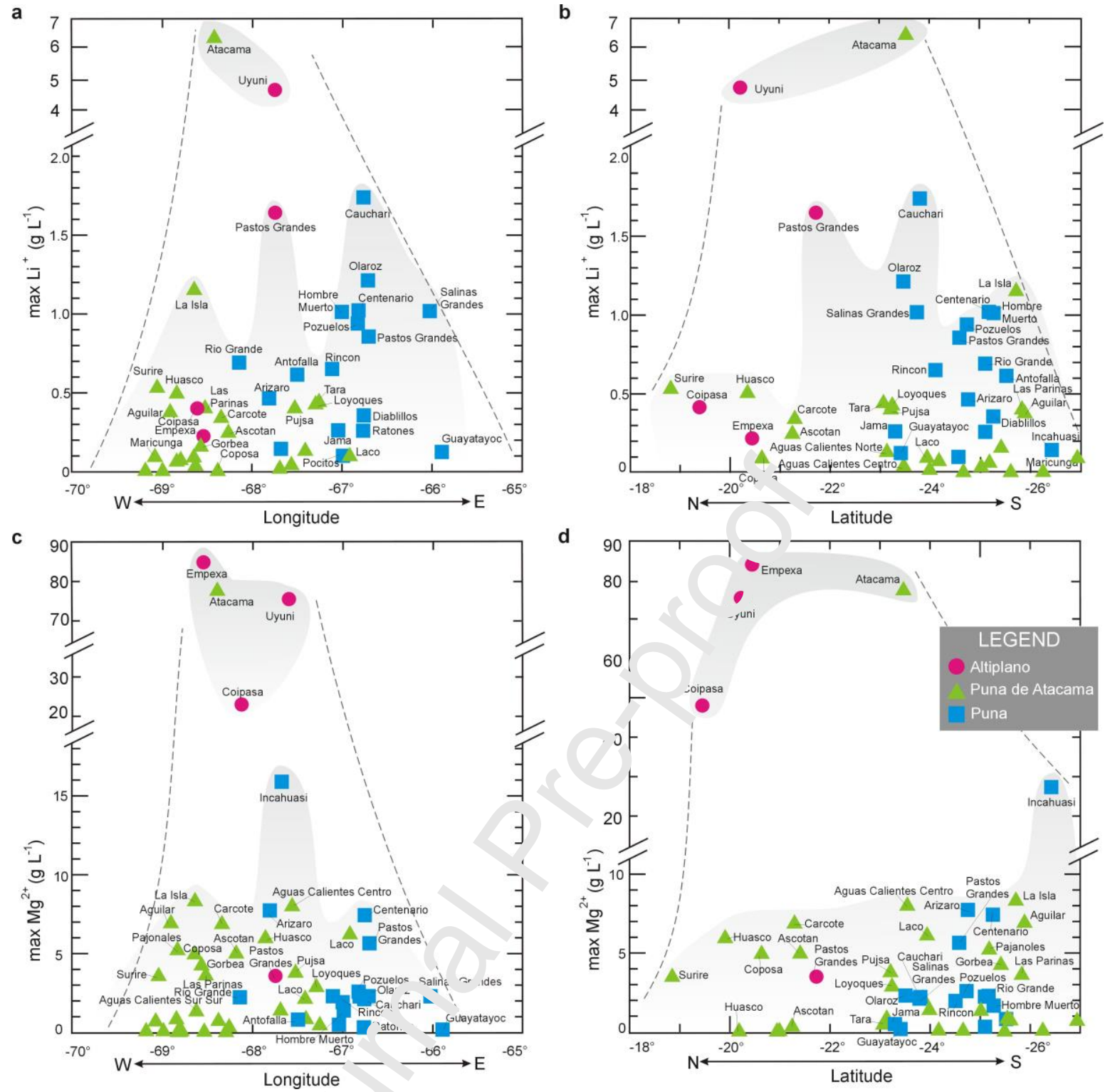

Figure 9. Scatter diar ran s showing the maximum $\mathrm{Li}^{+}$(upper) and $\mathrm{Mg}^{2+}$ (bottom) concentrations accora. $\cdot$ : is longitude (a and c), and latitude (b and d) of salars across the Lithium Crescent. Notice that the considered maximum $\mathrm{Li}^{+}$and $\mathrm{Mg}^{2+}$ concentrations for Atacama are of 6,400 and 80,000 $\mathrm{mg} \mathrm{L}^{-1}$, respectively (Moraga et al., 1974; Ide and Kunasz, 1989; Kunasz, 2006). Plotted data correspond to values summarized in Table 4.

\subsection{Link between salt pan and endorheic basin areas}

The surfaces of the 55 salt pans studied across the Andean plateau (Fig. 1) appear to be related to those of their respective basin catchments, as revealed by the very good correlation obtained comparing their areas: $\mathrm{R}=0.89$ (Fig. 10 a). Two proportional size ranges are observed: basin catchments of Uyuni, Atacama and Arizaro are 5 times larger than their 
salt pans, i.e., have a 1:5 size ratio (Fig. 10 a), whereas for the 52 remaining sites, salt pan to basin size proportions are close to the 1:10 ratio (Figs. $10 \mathrm{a}$ and b). Coipasa and Guayatayoc are the two salt pans that least fit either of these relationships (these two cases are discussed further down).
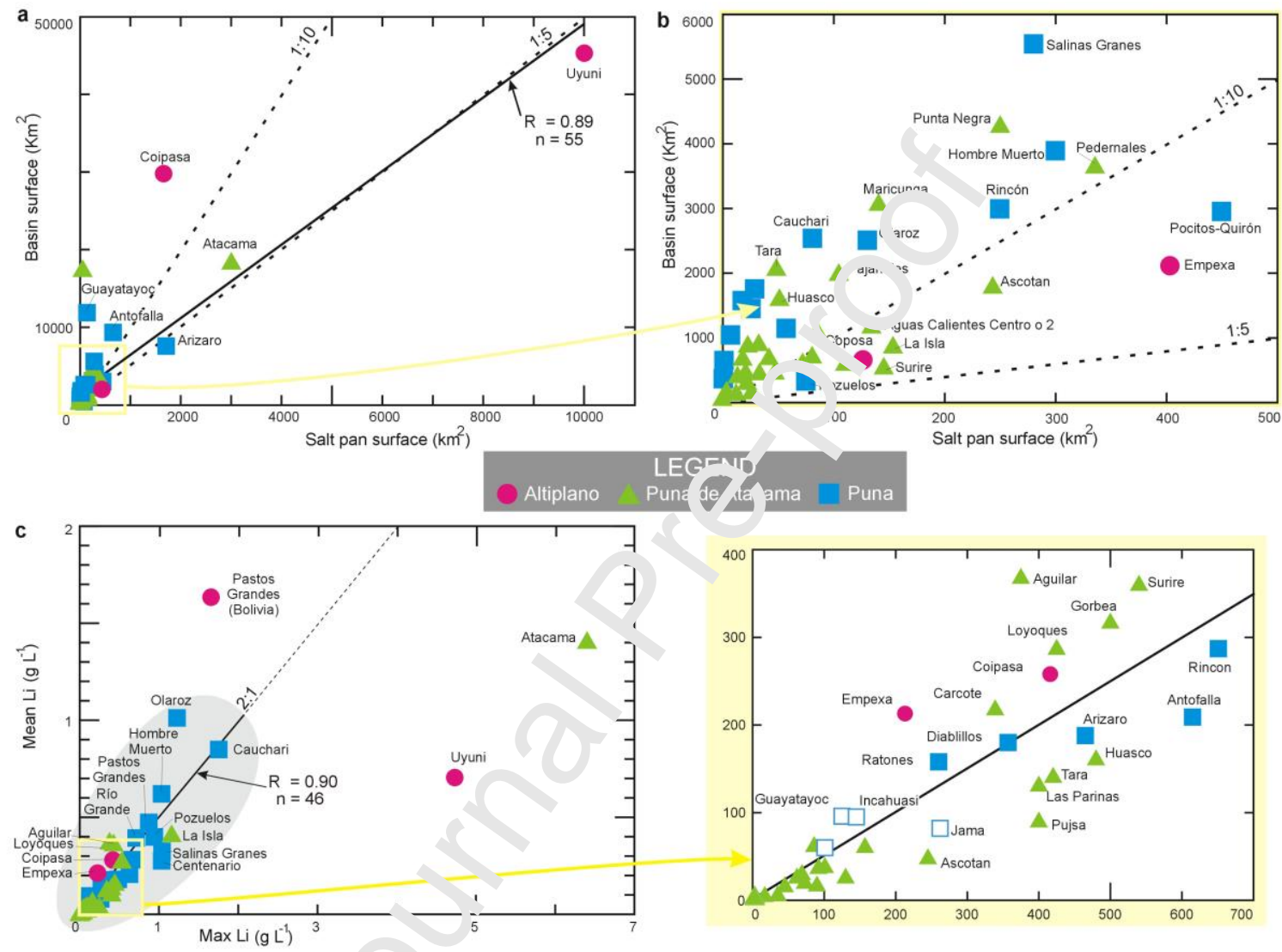

Figure 10. $a$ and $b$ ) Scatt $r$ diagrams showing the relations between the surfaces of salt pans and their respective basin catchments. a) The correlation $\mathrm{R}=0.89$ was computed by considering all 55 Andean salt pans according to values summarized in Table 1. Note that the correlation line (continuous stroke) is close to the 1:5 proportion (dashed line). b) This panel expands the inset (in yellow) and plots data for the smallest salt pans. Note that most salt pans group close the 1:10 proportion. c) A scatter diagram plotting the relationship between the maximum (Max) and mean Li concentrations according to values summarized in Table 4 . The regression $\mathrm{R}$ (continuous line) coincides with the stoichiometric proportion of 2:1 (dashed line) for 46 salt pans (n, gray area). Values for max/mean Li ratios are of 1 in Pastos Grandes (Bolivia), 7 in Uyuni, and 11 in Atacama. The inset offers an expanded view of the data displayed in the yellow box of panel c. $\mathrm{R}$ is the correlation coefficient (continuous lines), $\mathrm{n}$ is the number of salt pans. 
The good correlation between salt pan and endorheic basin areas and the two proportional size ranges are very interesting patterns that undoubtedly deserve further specific investigation. Although this is beyond the purpose of this paper, it can be suggested that these relationships may arise from common trends in regional geological history, including lithology (i.e., substrate, tectonics, volcanism, etc.) and exogenous processes (e.g. climaterelated such as regional aridity and its effect on rock weathering and erosion), across the Andean plateau.

Li-bearing Andean salt pans occur exclusively within ana theic basins. The onset of endorheism requires the convergence of the follo ${ }^{\mathrm{vH}_{i}}{ }_{\mathrm{r}}$ parameters: suitable basin configuration (topographic barriers surrounding low lvin $\mathrm{P}-$ and high evaporation $-\mathrm{E}$ - rates, where $\mathrm{P}<\mathrm{E}$ ), ' haı ${ }^{\top}$ substrate thus low erosion rates (in order for range-crossing rivers to fail incis $n_{8} d$,eply into the ranges and inhibit basin capture), and low aggradation rates (in or er for sedimentation not to overfill the isolated area), amongst other variables (Sobc: et al., 2003; Hilley and Strecker, 2005; GarcíaCastellanos, 2006; Tremblay et a1 2(11). Basement inherited heterogeneities (Hongn et al., 2007), Cenozoic Andean tectc. ics (actively uplifting ranges) and Neogene plateau rise were key factors for the formatı n of endorheic basins in the plateau, while the arid climate

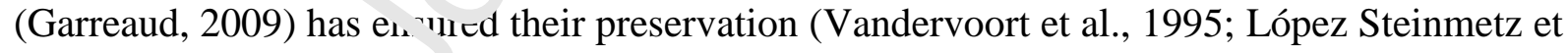
al., 2020b). Within an endorheic basin, weathering and erosion of the catchments supply the suspended and dissolved load that is transported by rivers towards the low-laying area, where sediments and other products accumulate. Under arid conditions, salt pans form on these lowlying and hydrologically isolated areas (Melvin, 1991; Warren, 2010). Consequently, there is a clear link between the formation of internally drained areas and salt pans. However, as natural processes are typically heterogeneous and complex (Becker and Braun, 1999; Paola et al., 2009), this link clearly does not imply that we can estimate or model the size of endorheic 
and saline units, let alone predict whether there might be proportionality between them. It could only be argued that if large catchments are more capable of generating a greater amount of suspended and dissolved load than smaller ones, then under similar conditions (i.e., geological history including lithology, deformation, volcanism and related hydrothermal processes, climate, etc.), large catchments would be required for the largest salt pans to form. For this reason, the fact that the size of salt pans adjusts proportionally to the size of endorheic basins, as revealed by our observations across the Andean plateau (Figs. 10 a and b), is a fascinating configuration for landscape studies. The salt na.'basin size proportionality could apply to other endorheic basins in arid regions. Fr, i i 'stance, the Qaidam Basin ( $c a$. $94^{\circ} \mathrm{E}-38^{\circ} \mathrm{N}$ ) in the northern Tibetan Plateau holds vorld-class Li-brine type deposits comprising $80 \%$ of the Li-brine resources found in C1. na (Keslar et al., 2012). The basin's surface is $121,000 \mathrm{~km}^{2}$, one-fourth of which cr v er by numerous saline lakes and playas ( $\mathrm{Yu}$ et al., 2013). According to this, the $\sim 1{ }^{1} \mathrm{~s}^{r}$.t $\mathrm{pan} / \mathrm{basin}$ size ratio in Qaidam is close to the proportion found in Uyuni. The props +ionality between the surfaces of salt pans and their endorheic basins should thus be choch or, in detail in other Tibetan Plateau basins and in other regions with internal drainage, $n$ order to confirm the application of this relationship to other parts of the globe.

The poor salt $\mu^{\urcorner} n$-vasin size association observed in the Guayatayoc and Coipasa salars appears to result from relatively late processes, i.e., younger than the basins. In the case of Guayatayoc, its basin is oversized with respect to the size of its salt pan $\left(11,805 \mathrm{~km}^{2}\right.$ and $140 \mathrm{~km}^{2}$, respectively). However, nearly half of the current extent of this basin formed in the Pleistocene, through the capture of the western watershed areas (López Steinmetz and Galli, 2015). This process resulted in the formation of a large $\left(>500 \mathrm{~km}^{2}\right)$ distributive fluvial system (sensu Weissman et al., 2015), which lead to the subdivision of the precursor flats and the formation of two individual salars and respective basins, Salinas Grandes and Guayatayoc. 
This means that, before the Pleistocene, the unified surface area of the basins (Salinas

Grandes + Guayatayoc; $\sim 11,000 \mathrm{~km}^{2}$ ?) would correlate with the area of the precursor salt pans (Grandes + Guayatayoc + megafan, $\sim 920 \mathrm{~km}^{2}$ ?). In the case of Coipasa and its oversized basin area, satellite imagery of geomorphological features suggests that the northern half of the basin's catchments (north of $18^{\circ} 50^{\prime} \mathrm{S}$ ) is a remnant of an ancient independent drainage system that could have been incorporated into the Coipasa basin through the capture of the Lauca River.

\subsection{Mean Li concentrations are half the maximum Li r ceared}

Brines in Andean salt pans show a 2:1 proportio 'ality between maximum Li values and mean concentrations (Fig. $10 \mathrm{c}$ ), with a correlat:0ı $\mathrm{R}=0.90$ for 46 salt pans. Atacama,

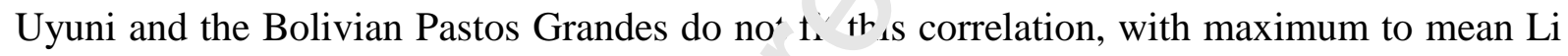
proportions of 11:1, 7:1, and 1:1, respe +iv ly. The high degree of correlation together with the exceptional number of salt pans f1ı ing the $2: 1$ proportion make this pattern a substantial feature across the Central Andes. It $\mathrm{m}$ an ns that maximum and mean Li concentrations can be considered as mutual proxies $i$ sur veying Li brine-type deposits. Accordingly, an indicative value of the mean concentrai in of Li brines in a salt pan can be estimated as half the value of the maximum measurec, aıu vice versa, a relationship that can be expressed as:

$$
\text { mean } \mathrm{Li} \approx 1 / 2 \max \mathrm{Li}(1)
$$

In the case where only few grade data were collected in one salt pan, the mean Li grade would be hard to determine. The difficulty in obtaining representative mean (and max) $\mathrm{Li}$ values arises from the need to acquire a large dataset in order for the mean $\mathrm{Li}$ (and max) grade to be confidently considered as representative of the real potentiality of the deposit in question (see Houston et al., 2011). However, despite the time elapsed since the beginning of the Andean Li rush, in general, the hydrochemistry of only a limited number of samples is 
available for each of Andean salt pans in the scientific literature, even today. In fact, a relatively restricted number of data is also a typical situation in the initial phases of most mining projects. This clearly represents a major drawback when estimating the mean $\mathrm{Li}$ grades (and max) of mining prospects. In this context, the formulation (1) proposed for predicting average $\mathrm{Li}$ values can provide a useful approach. It is important to note that the mean Li value obtained through equation (1) is valid from a statistic and regional perspective. Obviously, it does not replace the specific average value of a deposit obtained from a large dataset, but provides a useful order-of-magnitude indication whic that can be quite valuable (see for example the case of Salar de Olaroz in Fig. 10 c and in Table 4, where max Li measured is of $1,213 \mathrm{mg} \mathrm{L}^{-1}$ whereas the average $\mathrm{Li}$ valu that result from mining operations is of $841 \mathrm{mg} \mathrm{L}^{-1}$; Garcia et al., 2019).

The usefulness of the formulation pror $\mathrm{o}_{\llcorner} \cdot \mathrm{d}$ above lies in the fact that at any point in the exploration of a $\mathrm{Li}$ brine-type depc it, ne maximum measured Li concentration can be used to predict an indicative average , alue of its grade. The formulation (1) thus defines a dynamic approach to mean Li va'nes, which implies that the predicted mean Li will change and evolve as the dataset incre ' es curing prospection.

\subsection{Li grade as functic ${ }^{`}$ or salt pan / basin geomorphology}

As seen in previous sections, a regional assessment has made it possible to define a relationship between mean and maximum Li concentrations for Andean salars, and to identify a proportionality between the surfaces of the salt pans and basins. In order to test these proportionalities, the concentrations of $\mathrm{Li}$, mean and maximum, have been addressed with respect to the area of the salt pan or its basin catchments (Fig. 11). Despite the fact that the link between Li concentrations and surfaces does not follow a definite proportionality, there is some degree of relationship between Li grade and salt pan size. Larger salt pans do host, by 
and large, higher Li-grade brines than smaller pans (Fig. 11 a). This proportionality seems to change according to grade-size scales: i) a relationship of increasing Li with salt pan size is evident for the larger salt pans, i.e., more than $300 \mathrm{~km}^{2}(\mathrm{R}=0.83, \mathrm{n}=7$; Fig. $11 \mathrm{a})$; ii) this Ligrade/pan-surface relationship is also observed for salt pans having surfaces between 200 and $300 \mathrm{~km}^{2}(\mathrm{R}=0.87, \mathrm{n}=4$; Fig. 11, inset of panel a); and iii) a Li-grade/pan-surface relationship is also observed in those less than $\sim 150 \mathrm{~km}^{2}(\mathrm{R}=0.63, \mathrm{n}=23$, Fig. 11 a, see also details in panels $b$ and $c)$. These three proportionality ranges comprise most (i.e., 34) of the Andean salt pans, with 15 salt pans not fitting any relationship (Fig. $11 \mathrm{~b}$ ).
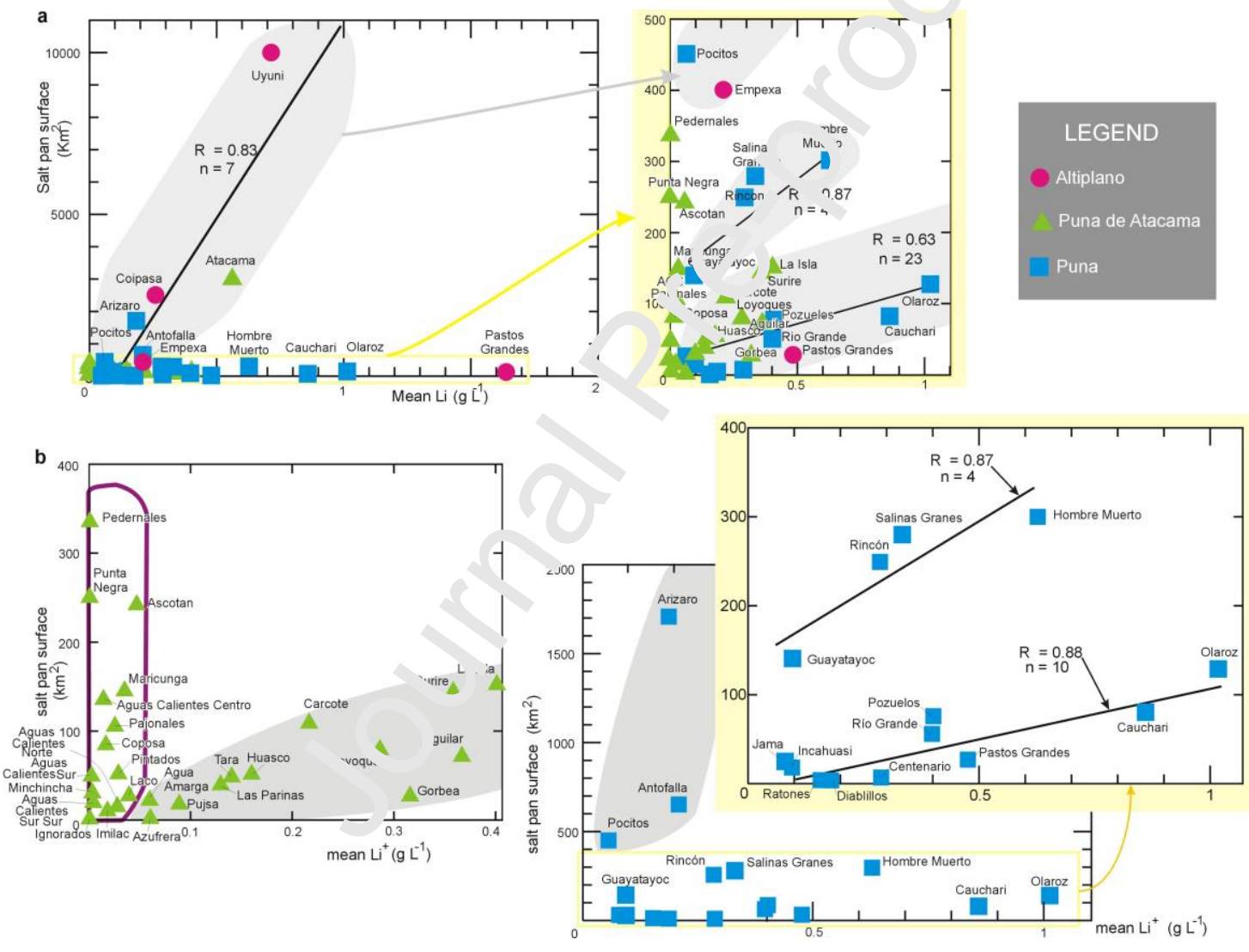

Figure 11. Scatter diagrams showing the relations between mean Li concentrations and pan surfaces for a) the 49 salt pans in the Andean plateau, b) salt pans from the Puna de Atacama, and c) salt pans from the Puna. Insets offer detailed views of the data displayed in the yellow boxes of panels a) and c). Gray areas group salt pans where there is some degree of proportionality between the mean Li values and the salt pans surfaces. In panel $b$, the purple thick line contours the 13 salt pans lacking a relationship between Li grade and salt pans surface. $\mathrm{R}$ is the correlation coefficient (continuous lines), $\mathrm{n}$ is the number of salt pans. 
Arguably, the dependence of Li concentration on processes occurring at the basin scale is not the most widespread concept, particularly in the Andean and Tibetan literature. In most studies, the rate of supply of Li-bearing waters from hydrothermal springs is deemed as being the essential parameter in controlling Li grades (e.g., Davis et al., 1986; Ide and Kunasz, 1989; Kesler et al., 2012; Godfrey et al., 2013). However, as discussed in section 5.1, thanks to recent investigations on isotopic systematics, it is now apparent that the primary sources of Li in the Andes, including what is supplied by hydrothermal springs, are restricted varieties of lithologies of the Paleozoic basement that underlies he plateau (Egenhoff and Lucassen, 2003; Peralta Arnold et al., 2017; García et al., 2 v1 ?: Meixner et al., 2019).

Likewise, not to be confused are the concepts of $\mathrm{L}:$ grades and Li reserves. Larger salt pans (i.e., of greater areal extent) do not necessarily contain greater Li reserves. This is because the total $\mathrm{Li}$ of a brine-type deposit (i. is reserves) is provided by the physical parameters of the aquifer (real size - i.e. hr rizontal areal extent plus thickness of the aquifer -, hydraulic conductivity, transmissivil, etc.), in addition to the actual Li grade in the brine.

Up to now, and contrarily ${ }^{+}$. ar erves, the sizes of salt pans or basins have not been related to Li levels, in the A. les ur elsewhere, nor have they ever been considered as an integral condition for higher $\mathbf{I} \mathbf{i}$ graded brines. However, regional data from the Andes show some degree of propori nailty between Li concentrations and the surface area of basins and pans. This might imply that, under otherwise comparable conditions (i.e., substrate and surface lithology, characteristics and density of structures, number, density and hydrochemistry of hydrothermal sources, climate, etc.), large salt pans in endorheic basins would generally contain brines with a higher lithium content than smaller ones.

\subsection{Lithium Crescent: when basin size matters}


The most relevant factors governing Li grades in salt pans are the existence of input sources of Li, hydrological isolation, and aridity (Munk et al., 2016). Based on the general tendency of increasing Li concentrations with salt pan/basin sizes (Fig. 11), it follows that $\mathrm{Li}$ grades should be also (at least partially, in addition to the factors mentioned above) dependent on a geomorphological feature: the salt pan area (or its catchment area; Fig. 12). As discussed above, under analogous conditions (i.e., substrate and surface lithology, characteristic and density of displaying structures, number, density, and hydrochemical characteristics of springs, climate, etc.), larger salt pans should be expected to mnlain higher Li-graded brines than smaller ones, which would be a very useful criterion f ${ }^{\mathrm{JI}}$ - 'lrveying brine-type deposits. A correspondence between Li grades and salar sizes mav is flect the importance of basin scale processes such as rock weathering, isolation, evaporatı`n, and time (López Steinmetz et al., 2020b). This would be consistent with the mor'e $\operatorname{rr}$ posed for the formation of the Atacama's and Olaroz's brines, which took place in $\mathrm{n}$-ar-surface setting through geochemical processes such as low-temperature weathering, waporation, formation of transition-zone brines, and ultimately crystallization of halite ${ }^{t_{0}} \mathrm{n}$,rease the concentration of $\mathrm{Li}$ in the brines (Munk et al., 2018; Franco et al., 202C, As already mentioned in section 5.1., other studies have reported Li isotopic data she vi..g that volcanic and Paleozoic basement rocks represent the primary source for Li 1. thu Andean plateau (Egenhoff and Lucassen, 2003; Peralta Arnold et al., 2017; García et al., 2019; Meixner et al., 2019). These models are consistent with the absence of a clear geographical distribution of $\mathrm{Li}$ in salars across the plateau, because $\mathrm{Li}$ is sourced from a lithological unit that is widespread the Paleozoic basement that underlies the salars across the plateau. On the other hand, the fact that Li levels increase with increasing salar size suggests that other processes are acting at the scale of the basin, and these are likely tied to geomorphology, and, presumably, the age of the basin. The implication of the latter would be that older basins had more time than younger ones to accumulate the products of 
weathering and evaporation. Time dependence of Li grades implies a significant role of the age of endorheism onset, of the history of Li supply and of the persistence of arid conditions.

In summary, the integrity of the available regional data evidences some degree of correspondence between Li grades and salar sizes. This thus implies that not only the largest but also the oldest salars would be the ones expected to contain the largest Li resources. The fact that Li grade could be a function of salt pan/basin geomorphology may provide an insight on new approaches toward understanding the formation of Andean salars, and, more generally, brine-type deposits worldwide.

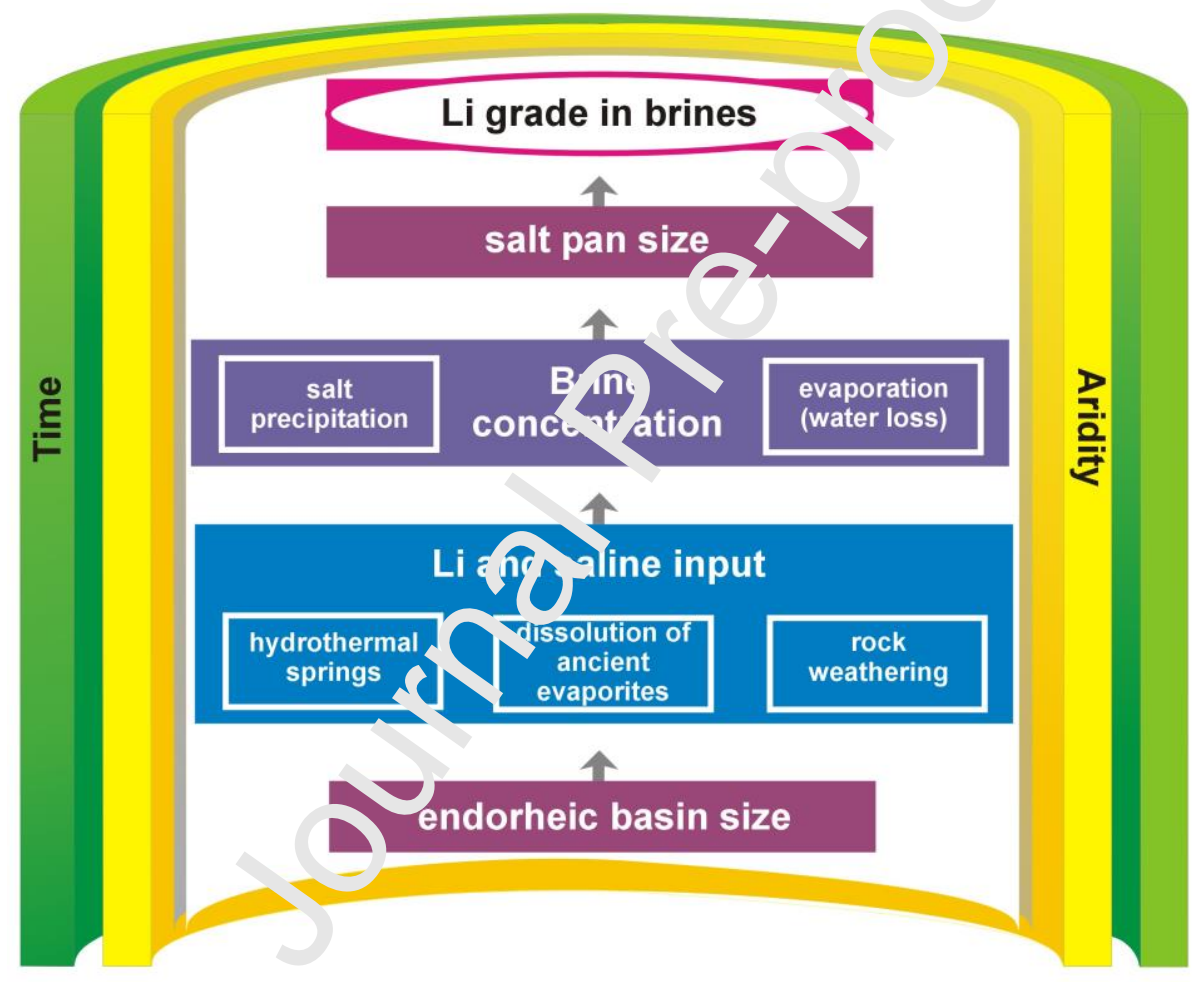

Figure 12. A schematic flow diagram illustrating Li -related processes from basin to salt pan (upwards). It illustrates the interplay between hydrological processes, climate and time, leading to Li accumulation (grade) in Andean brine-type deposits.

\section{Conclusions}


- The area involving all of the Andean Li-bearing salt pans extends beyond the Lithium Triangle and corresponds in fact to a curved crescent shape. We propose it be referred to as the Lithium Crescent.

- Andean brines are of the $\mathrm{Cl}^{-}-\mathrm{SO}_{4}{ }^{2-}$ type, and the compositional variability is marked by major cations: $\mathrm{Na}^{+}-\mathrm{Mg}^{2+}$ signatures largely predominate, with the exceptions of the $\mathrm{Mg}^{2+}>\mathrm{Na}^{+}$signature of Uyuni, and the $\mathrm{Na}^{+}-\mathrm{K}^{+}$signature in the Northern Puna salars (Argentina). High $\mathrm{Mg}^{2+}$ concentrations occur in the Altiplano (Bolivia), and $\mathrm{Ca}^{2+}$ has highest values in the Puna de Atacama (Chile).

- Li lacks of a clear geographical distribution pattern acr'ss 'ie Lithium Crescent, other than the fact that maximum $\mathrm{Li}^{+}$values occur in the centro-1 $66^{\circ} 30^{\prime}-68^{\circ} 30^{\prime} \mathrm{W}$ and $20^{\circ}-24^{\circ} \mathrm{S}$. Such an absenre or 9 geographical distribution in the $\mathrm{Li}$ pattern is likely a consequence of the fact t ta the primary source of Li is the Paleozoic basement, which underlies all salt pans a $\cdots, \mathrm{s}$ the Andean plateau.

- Li-bearing Andean salt pans are t: clusively hosted in endorheic basins. Across the Lithium Crescent, sizes of salt pa in a $\sim$ proportionally related to the extent of their endorheic basin surface. The size ratio I $^{r}$ the Qaidam Basin in the Tibetan Plateau is close to the proportions found at Uyur: 1:- salt pan/basin surface proportionality should thus be checked in detail in other regio - of internal drainage, in order to confirm the application of this relationship to other parts of the globe.

- In the Andes, measured maximum $\mathrm{Li}$ values (max $\mathrm{Li}$ ) are twice the mean $\mathrm{Li}$ concentrations: the equation mean $\mathrm{Li} \approx 1 / 2 \max \mathrm{Li}$ can be employed to predict indicative mean grades during brine-type deposit surveying in the Lithium Crescent.

- The concentrations of $\mathrm{Li}$ (mean or maximum) can be addressed indistinctly with respect to the area of the salt pan or its basin catchments. Larger salt pans host, in general, higher-grade Li brines than smaller ones. This proportionality changes according to grade-size scales of 
three groups: the largest salt pans of more than $300 \mathrm{~km}^{2}$; those having surfaces between 200 and $300 \mathrm{~km}^{2}$, and salt pans of less than $\sim 150 \mathrm{~km}^{2}$.

- Li levels depend on basin-scale processes, on geomorphology and, presumably, also on the age of the basin: therefore, it is likely the largest and oldest salars that are expected to hold the greatest Li concentrations.

\section{ACKNOWLEDGMENTS}

This research did not receive any specific grant from Iu nding agencies in the public, commercial, or not-for-profit sectors. We wish to thank +o C. Helvaci and five anonymous reviewers for their helpful comments that greatly ir preved this manuscript, as well as J.-A. Sanchez-Cabeza for editorial handling. The au he - declare no conflict of competing financial nor non-financial interests in relation to ㄴ. , vork herein.

Declaration of competing interests

The authors declare that they have $m \mathrm{k} \sim \mathrm{n}$ competing financial interests or personal relationships that could have appeared to influ nce ine work reported in this paper.

\section{REFERENCES}

Adad, M.J., López Steinmetz, R.L., Dávila, F.M., 2020. Seismic interpretation and Cenozoic tectonic evolution of the Pozuelos Basin, Andean Plateau, Argentina. Journal of South American Earth Sciences. doi:10.1016/j.jsames.2020.102938.

Allmendinger, R.W., Ramos, V.A., Jordan, T.E., Palma, M., Isacks, B.L., 1983. Paleogeography and Andean structural geometry, northwest Argentina. Tectonics. 2 (1), 1 16. 
Allmendinger, R.W., Gubbels, T., 1996. Pure and simple shear plateau uplift, Altiplano-Puna, Argentina and Bolivia. Tectonophysics. 259 (1-3), 1-13.

Allmendinger, R., Jordan, T., Kay, S., Isacks, B., 1997. The evolution of the Altiplano-Puna plateau of the Central Andes. Annual Reviews on Earth and Planetary Sciences. 25, 139174.

Alonso, H., Risacher, F., 1996. Geoquímica del Salar de Atacama, parte 1: origen de los componentes y balance salino. Revista Geológica de Chile. 23 (2), 113-122.

Alonso, R.N., Helvaci, C., Sureda, R.J., and Viramonte, J.G 1;९8. A new Tertiary borax deposit in the Andes. Mineralium Deposita. 23, 299-305.

Alonso, R.N., Jordan, T.E., Tabbutt, K.T., Vandervonrt, ?.S., 1991. Giant evaporite belts of the Neogene Central Andes. Geology. 19, 401-404. doi:10.1130/00917613(1991)019<0401:GEBOTN>2.3.CO;2

Alonso, R.N., Bookhagen, B., Carra $\left.{ }^{`}\right\urcorner$, B., Coutand, I., Haschke, M., Hilley, G.E., Schoenbohm, L., Sobel., E.R., Sı॰ ${ }^{\circ}$ ker, M.R., Trauth, M.H., Villanueva, A., 2006. Tectonics, climate, and landscrne wolution of the southern central Andes: the Argentine Puna Plateau and adjacent r r. rions between 22 and $30^{\circ} \mathrm{S}$, in: Oncken, Chong, O., Franz, G., Giese, P., Götze, H.-J.. Rànrs, V.A., Strecker, M.R., Wigger, P. (Eds.), The Andes Active Subduction Orogeny. Spınger, Berlin, pp. 265-284.

An, J.W., Kang, D.J., Tran, K.T., Kim, M.J., Lim, T., Tran, T., 2012. Recovery of lithium from Uyuni salar brine. Hydrometallurgy. 64-70, 117-118.

Babeyko, Y.A., Sobolev, S.V., Trumbull, R.B., Oncken, O., Lavier, L.L., 2002. Numerical models of crustal scale convection and partial melting beneath the Altiplano-Puna plateau. Earth and Planetary Science Letters. 199, 373-388.

Baby, P., Rochat, P., Mascle, G., Herail, G., 1997. Neogene shortening contribution to crustal thickening in the back arc of the Central Andes. Geology. 25 (10), 883-886. 
Belmonte, A., 2002. Krustale Seismizit7t, Struktur und Rheologie der Oberplatte zwischen der Pr7kordillere und dem magmatischen Bogen in Nordchile (228-248S). PhD thesis, Freie Universitat Berlin, Germany.

Banks, D., Markland, H., Smith, P.V., Mendez, C., Rodriguez, J., Huerta, A., Saether, O.M., 2004. Distribution, salinity and $\mathrm{pH}$ dependence of elements in surface waters of the catchment areas of the Salars of Coipasa and Uyuni, Bolivian Altiplano. J. of Geochem. Explor. 84, 141-166.

Becker, A., Braun, P., 199. Disaggregation, aggregation and sna. modelling. Journal of Hydrology. 217, 239-252.

Bevacqua, P.S.J., 1992. Geomorfología del Salar de Ata:ama y estratigrafía de su núcleo y delta, Segunda Región de Antofagasta, Chile. 'ndergraduate thesis (unpublished). Universidad Católica del Norte, Antofagast ‘, ? 24 p.

Borda, L.G., Franco, M.G., Córdoba, F., G ،rcía, M.G., 2016. Geoquímica del Li y As en el salar de Olaroz, Puna de Jujuy. Pesultados preliminares. 4th Reunión Argentina de Geoquímica de la Superficie (I/ R. $\left.{ }^{\prime}{ }_{J} S U\right)$. Actas de Resúmenes, 159.

Boschetti, T., Cortecci, G., Baı vier1, M., Mussi, M., 2007. New and past geochemical data on fresh to brine waters of the Salar de Atacama and Andean Altiplano, northern Chile. Geofluids. 7, 33-50.

Bouttt, D.F., Hynek, S.A., Munk, L.A., Corenthal, L.G., 2016. Rapid recharge of fresh water to the halite-hosted brined aquifer of Salar de Atacama, Chile. Hydrological Processes. doi:10.1002/hyp.10994.

Brackebusch, L., 1883. Estudios sobre la Formación Petrolífera de Jujuy. Boletín de la Academia Nacional de Ciencias de Córdoba. 5, 137-252.

Brackebusch, L., 1891. Mapa geológico del interior de la República Argentina, escala 1:1.000.000. Gotha. 
Canavan, R.R., Carrapa, B., Clementz, M.T., Quade, J., DeCelles, P., Schoenbohm, L.M., 2014. Early Cenozoic uplift of the Puna Plateau, Central Andes, based on stable isotope paleoaltimetry of hydrated volcanic glass. Geology. 42 (5), 447-450. doi:10.1130/G35239.1.

Catalano, L.R., 1964. Boro-Berilio-Litio (una nueva fuente natural de energía). Servicio Nacional Geológico Minero. Ministerio De Economía de la Nación Argentina, Buenos Aires, 99 p.

Carmona, V., Pueyo, J.J., Taberner, C., Chong, G., Thirlwall M., 2000. Solute inputs in the Salar de Atacama (N. Chile). J. of Geochem. Explor. 69 « 449-452.

Clark, F.W., 1924. The data of geochemistry, fifth ed. I.s. Geol. Survey Bull. 770, 841 p.

COCHILCO, 2013. Compilación de informes so'bre Mercado internacional del litio y potencial del litio en salares del norte c. C'hile. Comisión Chilena del Cobre y SerNaGeoMin, Secretaría de N.nería, Santiago de Chile, 319 p. http://www.cochilco.cl/estudios/into litio.asp.

Coira, B., Kay, S.M., Viramonte J 1993. Upper Cenozoic magmatic evolution of the Argentine Puna - A mode for changing subduction geometry. International Geology Review. 35 (8), 677-720.

Corenthal, L.G., Boutt, ?.I., Hynek, S.A., Munk, L.A., 2016. Regional groundwater flow and accumulation of a massive evaporate deposit at the margin of the Chilean Altiplano. Geophysical Research Letters. 43 (15), 8017-8025.

Crespo, P., Palma, H., Quintanilla, J., Quispe, L., 1987. Tratamiento químico de salmueras del Salar de Uyuni, Potosí. UMSa-ORSTOM, Informe 7.

Davis, J., Friedman, I., Gleason, J., 1986. Origin of the lithium-rich brine, Clayton Valley, Nevada. U.S. Geol. Surv. Bull. 1622, 131-138. 
Dingman, R.J., 1967. Geology and ground-water resources of the northern part of the Salar de Atacama, Antofagasta Province, Chile. U.S. Geological Survey Bulletin. 1219.

Durán Iriza, R.J., 2012. Modelación numérica y su contribución al estudio del comportamiento hidrogeológico del sector SW del acuífero del Salar de Atacama, II Región de Antofagasta, Chile. Msc Thesis. Universidad de Chile, Facultad de Ciencias Físicas y Matemáticas, 201 p.

Egenhoff, S.O., Lucassen, F., 2003. Chemical and isotopic composition of lower to upper Ordovician sedimentary rocks (Central Andes /South Bnlivi?): implications for their source. Journal of Geology. 111, 487-497.

Ericksen, G.E., 1961. Rhyolite tuff, a source of the sai ${ }^{i s}$ of northern Chile. Geol. Survey Research. U.S. Geological Survey Professional Pa’eı. 424, C224-C225.

Ericksen, G.E., 1963. Geology of the salt depo si. ard the salt industry of northern Chile. U.S. Geological Survey. Open-File Report, 16 , p.

Ericksen, G.E., Chong, G., Vila, T., 1; 76 a. Lithium resources of salars in the central Andes. U.S. Geological Survey Profession. 1'’aper. 1005, 66-74.

Ericksen, G., Chong, G., Vila, '`, 1976b. Lithium resources of salars in the central Andes, in: Vine, J.D., (Ed.), Lithium Pesources and Requirements by the Year 2000. U.S. Geological Survey Professional ?7pur. 1005, 66-74.

Ericksen, G.E., Vine, J.D., Ballon, R., 1977. Lithium-rich brines at Salar de Uyuni and nearby salars in southwestern Bolivia. U.S. Geological Survey. Open-File Repository. 77-615, 52 p.

Ericksen, G.E., Salas, R., 1977. Geology and resources of salars in the central Andes. U.S. Geological Survey. Open File Repository. 88-210, 51 p. 
Ericksen, G.E., Vine, J.D., Ballon, R.A., 1978. Chemical composition and distribution of lithium-rich brines in salar de Uyuni and nearby salars in southwestern Bolivia. Energy. 3 (3), 355-363.

Ericksen, G.E., Salas, R., 1987. Geology and resources of salars in the central Andes. U.S. Geological Survey. Open File Repository. 88-210, 51 p.

Eugster, H.P., 1980. Geochemistry of evaporitic lacustrine deposits. Ann. Rev. Earth Planet Sciences. 8, 35-63.

Franco, M.G., Borda, L., García, M.G., López Steinmetz, R.L Flu res, P., Córdoba, F., 2016. Geochemical and sedimentological characterization st he Salar de Olaroz, northern Argentinean Puna, Central Andes. 3rd Internationa, Workshop on Lithium, Industrial Minerals and Energy, Jujuy, Argentina.

Franco, M.G., Peralta Arnold, Y.J., Santam aı '_.D., López Steinmetz, R.L., Tassi, F., Venturi, S., Jofré, C.B., Caffe, P.J., C rrd sba, F.E., 2020. Chemical and isotopic features of Li-rich brines from the Salar de Ola `z, Central Andes of NW Argentina, 2020. Journal of South American Earth Sciences $1 C 2$ 10742. doi:10.1016/j.jsames.2020.102742.

Garcés, I., López, P.L., Ai rué, L.F., Chong, G., Vallès, V., Gimeno, M.J., 1996. Características geoquímı. generales del sistema salino del Salar de Llamara (Chile). Estudios Geológicos. 5 _, 23-35.

García, M.G., Borda, L.G., Godfrey, L.V., López Steinmetz, R.L., Losada Calderón, A., 2019. Characterization of lithium cycling in the Salar de Olaroz, Central Andes, using a geochemical and isotopic approach. Chemical Geology. 531, 119340. doi:10.1016/j.chemgeo.2019.119340.

García-Castellanos, D., 2006. Long-term evolution of tectonic lakes: Climatic controls on the development of internally drained basins, in: Willett, S.D., Hovius, N., Brandon, M.T., Fisher, D.M., (Eds.), Tectonics, Climate, and Landscape Evolution. Geological Society of 
America Special Paper, 398. Penrose Conference Series, 283-294. doi:10.1130/2006.2398(17).

Garzione, C.N., Hoke, G.D., Libarkin, J.C., Withers, S., MacFadden, B., Eiler, J., Ghosh, P., Mulch, A., 2008. Rise of the Andes. Sciences. 320 (5881), 1304-1307. doi:10.1126/science.1148615.

Garzione, C.N., McQuarrie, N., Perez, N.D., Ehlers, T.A., Beck, S.L., Kar, N., Eichelberger, Chapman, A.D., Ward, K.M., Ducea, M.N., Lease, R.O., Poulsen, C.J., Wagner, L.S., Saylor, J.E., Zandt, G., Horton, B.K., 2017. Tectonic Evnluli Plateau and Implications for the Growthof Plateaus. An ıua ${ }^{1}$ Keview of Earth and Planetary Sciences. 45, 29-59.

Garreaud, R.D., 2009. The Andes climate and weather. . dv. in Geosci. 22, 3-11.

Garrett, D.E., 2004. Handbook of lithium 21 ratural calcium chloride: their deposits, processing, uses and properties, fist e. F'sevier Academic Press.

Gianni, G.M., Dávila, F., Echaurren, A. Fennell, L., Tobal, J., Navarrete, C.R., Quezada, P., Folguera, A., Giménez, M., 2018. $\Delta$ geodynamic model linking Cretaceous orogeny, arc migration, foreland basin s. bsiaence and marine ingression in southern South America. Earth-Science Reviews. $1 \imath 5$ 437-462. doi:10.1016/j.earscirev.2018.06.016.

Godfrey, L.V., Chan, L. H., Alonso, R.N., Lowenstein, T.K., McDonough, W.F., Houston, J., Li, J., Bobst, A., Jordan, T.E., 2013. The role of climate in the accumulation of lithium-rich brine in the Central Andes. Applied Geochemistry. 38, 92-102.

Godfrey, L., Alvarez-Amado, F., 2020. Volcanic and saline lithium input to the Salar de Atacama. Minerals. 10, 201. doi:10.3390/min10020201.

Götze, H.-J., Krause, S., 2002. The Central Andean gravity high, a relic of an old subduction complex? Journal of South American Earth Sciences. 14, 799-811. 
Gruber, P., Medina, P., 2010. Global lithium availability: a constraint for electric vehicles? Master thesis, University of Michigan, $76 \mathrm{p}$.

Hardie, L., Eugster, H., 1970. The evolution of closed-basin brines. Fiftieth Anniversary Symposia, Mineralogy and Geochemistry of Non-Marine Evaporites. Mineralogical Society of America Special Publication. 273-290.

Helvac1, C., Mordogan, H., Çolak, M., Gündogan, I, 2004, Presence and distribution of lithium in borate deposits and some recent lake waters of west-central Turkey. International Geology Review. 46, 177-190. doi:10.2747/00าn-c'14.46.2.177.

Herail, G., Oller, J., Baby, P., Bonhomme, M., Soler, P., 'צ׳' strike-slip faulting, thrusting and related basins in the Cenozoic evolution of the southern branch of the Bolivian Orocline. Tectonophysics. 259, 201-212.

Hilley, G.E., Strecker, M.R., 2005. Processes oi ns illatory basin filling and excavation in a tectonically active orogen: Quebrada 'el ‘ 'oro basin, NW Argentina. Geological Society of America Bulletin. 117, 887-901. doı. ${ }^{10.1130 / B 25602.1 .}$

Hongn, F.D., Del Papa, C., Powall, I, Petrinovic, I., Mon, R., Deraco, V., 2007. Middle Eocene deformation and simuntation in the Puna-Eastern Cordillera transition $\left(23^{\circ}\right.$ $26^{\circ} \mathrm{S}$ ): control by preexisinr, heterogeneities on the pattern of initial Andean shortening. Geology. 35, 271-2,' uvi:10.1130/G23189A.1.

Houston, J., Butcher, A., Ehren, P., Evans, K., Godfrey, L., 2011. The evaluation of brine prospects and the requirement for modifications to filing standards. Economic Geology. $106,1225-1239$.

Ide, F., Kunasz, I.A., 1989. Origin of lithium in Salar de Atacama, northern Chile, in: Ericken, G.E., Cañas Pinochet, M.T., Reinemund, J.A. (Eds.), Geology of the Andes and its relation to hydrocarbon and mineral resources. Circum-Pacific Council for Energy and Mineral Resources Earth Science Series, 11, pp. 165-172. 
Isacks, B., 1988. Uplift of the Central Andean Plateau and bending of the Bolivian orocline. Journal of Geophysical Research: Solid Earth. 93, 3211-3231. doi:10.1029/JB093iB04p03211.

Jordan, T.E., Nester, P.L., Blanco, N., Hoke, G.D., Dávila, F., Tomlinson, A.J., 2010. Uplift of the Altiplano-Puna plateau: A view from the west. Tectonics. 29, TC5007. doi:10.1029/2010TC002661.

Kaseman, S.A., Meixner, A., Erzinger, J., Viramonte, J.G., Alonso, R.N., Franz, G., 2004. Boron isotope composition of the geothermal fluids and birate minerals from salar deposits (central Andes/NW Argentina). Journal of Sou il merican Earth Sciences. 16 (8), 685-697. doi:10.1016/j.jsames.2003.12.004.

Kay, S.M., Coira, B., Viramonte, J., 1994. Young m-fı hack arc volcanic rocks as indicators of continental lithospheric delamination $x$ es $h$ the Argentine Puna plateau, central Andes. Journal of Geophysical Resea. ‘h· solid Earth. 99 (B12), 24323-24339.

Kesler, S.E., Gruber, P.W., Medina, เ.4., Keoleian, G.A., Everson, M.P., Wallington, T.J., 2012. Global lithium resours ${ }^{\circ}$ : $r$ lative importance of pegmatites, brine and other deposits. Ore Geology Revı ‘ 48, 55-69.

Kistler, R.B., Helvac1, C., 1צ`4 Boron and Borates. In: Carr DD (Ed.) Industrial Minerals and Rocks. Society of Miniız, Metallurgy and Exploration. $6^{\text {th }}$ Edition, 171-186.

Kunasz, I.A., 1976. Lithium resources - prospects for the future. In: Vine JD (Ed.) Lithium Resources and Requirements by the Year 2000. U.S. Geological Survey Professional Paper. 1005, 26-30.

Kunasz, I.A., 2006. Lithium resources, in: Kogel, J.E., Trivedi, N.C., Barker, J.M., Krukowski, S.T. (Eds.), Industrial minerals and rocks, commodities, markets and uses. Society for Mining, Metallurgy, and Exploration. 
Langbein, W.B., 1961. Salinity and hydrology of closed lakes. U.S. Geological Survey Professional Paper. 412, 20 p.

Li, X., Mo, Y., Qing, W., Shao, S., Tang, C.Y., Li, J., 2019a. Membrane-based technologies for lithium recovery from water lithium resources: A review. Journal of Membrane Science. 591. doi:10.1016/j.memsci.2019.117317.

Li, Q., Fan, Q., Wang, J., Qin, J., Zhang, X., Wei, H., Du, Y., Shan, F., 2019b. Hydrochemistry, distribution and formation of lithium-rich brines in salt lakes on the Qinghai-Tibetan Plateau. Minerals. 9, 528. doi:10.3390/minony` 528.

López, P.L., Auqué, L.F., Garcés, I., Chong, G., Vallès, V , U. meno, M.J., 1996. Aplicaciones de la modelización geoquímica al estudio de pautas e - olutivas en las salmueras del Salar de Llamara (Chile). Aproximación de método inversc Estudios Geológicos. 52, 197-209.

López Julián, P.L., Garcés Millás, I.M., 2001. ' R' جç ones geoquímicas entre los distintos tipos de aguas superficiales del salar de _uri.e (Chile). Departamento Ciencias de la Tierra, Universidad de Zaragoza, 10 p.

López Steinmetz, R.L., 2017. I ithi $\mathrm{m}_{\mathbf{}_{-}}$and boron-bearing brines in the Central Andes: exploring hydrofacies on th easiern Puna plateau between $23^{\circ}$ and $23^{\circ} 30^{\prime} \mathrm{S}$. Mineralium Deposita. 52, 35-50.

López Steinmetz, R.L. údli, C.I., 2015. Hydrological change during the PleistoceneHolocene transition associated with the Last Glacial Maximum-Altithermal in the eastern border of northern Puna. Andean Geology. 42 (1), 1-19.

López Steinmetz, R.L., Fong, S.B., 2019. Water legislation in the context of lithium mining in Argentina. Resources Policy, 64, 101510. doi:10.1016/j.resourpol.2019.101510.

López Steinmetz, R.L., Montero-López, C., 2019. Stratigraphy and sedimentary environments of the Villa María and Peña Colorada formations (Paleogene), westernmost Argentine plateau. Latin American Journal of Sedimentology and Basin Analysis. 26 (1), 39-56. 
López Steinmetz, R.L., Salvi, S., García, M.G., Béziat, D., Franco, G., Constantini, O., Córdoba, F., Caffe, P.J., 2018. Northern Puna plateau-scale survey of Li brine-type deposits in the Andes of NW Argentina. Journal of Geochemical Exploration. 190, 26-38.

López Steinmetz, R.L., Salvi, S., Sarchi, C., Santamans, C., López Steinmetz, L.C., 2020a. Lithium and brine geochemistry in the salars of the Southern Puna, Andean plateau of Argentina. Economic Geology. 115 (5), 1079-1096. doi:10.5382/econgeo.4754.

López Steinmetz, R.L., Avila, P., Dávila, F., 2020b. Landscape and drainage evolution during the Cenozoic in the Salinas Grandes Basin, Andean Pluteau of NW Argentina.

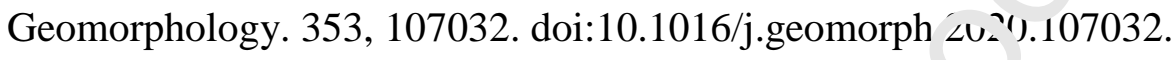

López Steinmetz, R.L., Avila, P., Dávila, F., 2020c. Lana rape and drainage evolution during the Cenozoic in the Salinas Grandes Basin 5 ndean Plateau of NW Argentina. Geomorphology. 353, 107032. doi:10.1016'j. ${ }^{\prime} \cdot n^{\prime} .10 r p h .2020 .107032$.

Lowenstein, T., Risacher, F., 2009. Clo ${ }^{` d}$ jasin brine evolution and the influence of $\mathrm{Ca}-\mathrm{Cl}$ inflow waters. Death Valley and Bi: tol Dry Lake, California, Qaidam Basin, China, and Salar de Atacama, Chile. Aquat Gr $\%$ hem. 15, 71-94.

Mardones, L., 1986. Caracter: ticas geologicas e hidrogeologicas del Salar de Atacama. In Lagos, G. (Ed.), El litio: Tr. nuevo recurso para Chile. Universidad de Chile, Santiago, Chile, pp. 181-216.

Mardones, L., Chong, G., 1991. Consecuencias hidrológicas de la explotación del Salar de Atacama, Norte de Chile. 6th Congreso Geológico Chileno. Resúmenes expandidos, 719722.

Maro, G., Caffe, P.J., Báez, W., 2017. Volcanismo monogenético máfico cenozoico de la Puna. 20th Congreso Geológico Argentino, Relatorio, 548-577.

McQuarrie, N., 2002. The kinematic history of the Central Andean fold-thrust belt, Bolivia: implications for building a high plateau. GSA Bulletin. 114 (8), 950-963. 
Meixner, A., Sarchi, C., Lucassen, F., Becchio, R., Caffe, P.J., Lindsay, J., Rosner, M., Kasemann, S.A., 2019. Lithium concentrations and isotope signatures of Palaeozoic basement rocks and Cenozoic volcanic rocks from the Central Andean arc and back-arc. Mineralium Deposita. doi:10.1007/s00126-019-00915-2.

Melvin, J.L., 1991. Evaporites, Petroleum and Mineral Resources. Developments in Sedimentology, fiftieth ed. Elsevier, 556 p.

Mohr, S., Mudd, G., Giurco, D., 2010. Lithium Resources and Production: a critical global assessment. Prepared for CSIRO Minerals Down Under Fla ship, by the Institute for Sustainable Futures, University of Technology, $S \backslash$ unc $y$, and Department of Civil Engineering, Monash University. Final Report, 107 n.

Montero-López, C., Hongn, F., López Steinmetz, P..L., Aramayo, A., Pingel, H., Strecker, M.R., Cottle, J.M., Bianchi, C., 2020. Dev lı. im ınt of an incipient Paleogene topography between the present-day eastern ande $n$ r ateau (Puna) and the Eastern Cordillera, southern Central Andes, NW Argentina. Bas1.. Research. doi:10.1111/bre.12510.

Moraga, B.A., Chong, D.G., Forttr N. A.., Henriquez, A.H., 1974. Estudio geológico del Salar de Atacama, Provincia de f. ttotagasta. Instituto de Investigaciones Geológicas Boliviano. $29,56 \mathrm{p}$.

Mpodozis, C., Ramos, ' ' , i 989 . The Andes of Chile and Argentina. In: Ericksen, G., CañasPinochet, M., Reinemund, J. (Eds.), Geology of the Andes and its Relation to Hidrocarbon and Mineral Resources, Circum-Apcific Council for Energy and Mineral Resources Earth Sciences Series. 11, 59-90.

Munk, L.A., Hynek, S.A., Bradley, D., Boutt, D., Labay, K., Jochens, H., 2016. Lithium brines: A Global Perspective. Reviews in Economic Geology. 18, 339-365. 
Munk, L.A., Boutt, D.F., Hynek, S.A., Moran, B.J., 2018. Hydrogeochemical fluxes and processes contributing to the formation of lithium-enriched brines in a hyper-arid continental basin. Chemical Geology. 493, 37-57.

Muñoz, N., Charrier, R., 1996. Uplift of the western border of the Altiplano on a west-vergent thrust system, northern Chile. Journal of South American Earth Sciences. 9, 171-181.

Orberger, B., Rojas, W., Millot, R., Flehoc, C., 2015. Stable isotopes (Li, O, H) combined with chemistry: powerful tracers for Li origins in Salar deposits from the Puna region, Argentina. Procedia Earth and Planetary Science. 13, 307-311.

Ovejero Toledo, A., Alonso, R.N., Ruiz, T., Quiroga, A.C., ?UU9. Evapofacies halítica en el Salar del Rincón, Departamento Los Andes, Salta n’vista de la Asociación Geológica Argentina. 64 (3), 493-500.

Paola, C., Kyle, S., Mohrig, D., Reinhardt, '.., $)$ J9. The "unreasonable effectiveness" of stratigraphic and geomorphic e ner ments. Earth-Science Reviews. 97, 1-43. doi:10.1016/j.earscirev.2009.05.00s.

Peralta Arnold, Y.J., Cabssi, J., Təсsi, F, Caffe, J.P., Vaselli, O., 2017. Fluid geochemistry of a deep-seated geothermal re: ource in the Puna plateau (Jujuy Province, Argentina). Journal of Volcanology and Gentı^rr.lal Research. doi:10.1016/j.jvolgeores.2017.03.030.

Ramos, V., Cristallinı, F., Pérez, D., 2002. The Pampean flat-slab of the Central Andes. Journal of South American Earth Sciences. 15, 59-78.

Rettig, S.L., Jones, B.F., Risacher, F., 1987. Geochemical evolution of brines in the Salar de Uyuni, Bolivia. Chemical Geology. 30, 57-79.

Riley, J.P., Tongudai, M., 1964. The lithium content of sea water. Deep Sea Research and Oceanographic Abstracts. 11 (4), 563-568. doi:10.1016/0011-7471(64)90002-6.

Risacher, F., Fritz, B., 1991. Quaternary geochemical evolution of the Salar of Uyuni and Coipasa, Central Altiplano, Bolivia. Chemical Geology. 90, 211-231. 
Risacher, F., Alonso, H., 1996. Geoquímica del Salar de Atacama, parte 2: evolución de las aguas. Revista Geológica de Chile. 23 (2), 123-134.

Risacher, F., Alonso, H., Salazar, C., 1999. Geoquímica de aguas en cuencas cerradas: I, II y III Regiones - Chile. Convenio de Cooperación Dirección General de Aguas de Chile, Universidad Católica del Norte, Institut de Recherche pour le Developpement. Report 51, $781 \mathrm{p}$.

Risacher, F., Fritz, B., 2000. Bromine geochemistry of Salar de Uyuni and deeper salt crusts, Central Altiplano, Bolivia. Chemical Geology. 167, 373-39?

Risacher, F., Alonso, H., Salazar, C., 2002. Hydrochemi «y or two adjacent saline lakes in the Andes of northern Chile. Chemical Geology. 187 ? -57.

Risacher, F., Alonso, H., Salazar, C., 2003. The orig`n ` + brines and salts in Chilean Salars: a hydrochemical review. Earth-Science Revic is. 6', 249-292.

Risacher, F., Fritz, B., 2009. Origin of $\operatorname{san}^{+} a^{\top} d$ brine evolution of Bolivian and Chilean Salars. Aquat. Geochemistry. 15, 123-157.

Ruetenik, G.A., Hoke, G.D., Mourha, R., Val, P., 2018. Regional landscape response to thrust belt dynamics: The Iglesia L sin, Argentina. Basin Research. 30. doi:10.1111/bre.12295.

Salas, J., Aravena, R., Guznı́n E., Comellà, O., Guimerà, J., Tore, C., Von Igel, W., Fock,

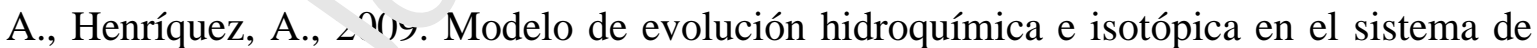
recarga del Salar de Atacama a través de su margen E. 12th Congreso Geológico Chileno, $1-4$.

Scandiffio, G., Alvarez, M., 1990. Informe geoquímico sobre la zona geotérmica de Laguna Colorada, Bolivia. Geothermal investigations with isotope and geochemical techniques in Latin American. Proc. of a Final Res. Co-ordination Meeting, Organismo Internacional de Energía Atómica, Costa Rica, 77-113. 
Scandiffio, G., Rodríguez, J., 1990. Geochemical report on the Sajama geothermal area, Bolivia. Geothermal investigations with isotope and geochemical techniques in Latin American. Proc of a Final Res Co-ordination Meeting, Organismo Internacional de Energía Atómica, Costa Rica, 114-168.

Schmidt, N., 2010. Hydrological and hydrochemical investigations at the Salar de Uyuni (Bolivia) with regard to the extraction of lithium. FOG. 26.

Schurr, B., Asch, G., Rietbrock, A., Kind, R., Pardo, M., Heit, B., Monfret, T., 1999. Seismicity and average velocities beneath the argentino f.na plateau. Geophysical Research Letters. 26 (19), 3025-3028.

Scott, E.M., Allen, M.B., Macpherson, C.G., McCaffrev, K.J.W., Davidson, J.P., Saville, C., Ducea, M.N., 2018. Andean surface uplift constrə:inc ${ }^{\gamma}$ by radiogenic isotopes of arc lavas. Nature Communications. 9, 969. doi:10.10?9» +1 ,67-018-03173-4.

Sempere, T., Butler, R.F., Richards, D.. ' ' Marshall, L.G., Sharp, W. y Swisher, C.C. 1997. Stratigraphy and chronology of $\mathrm{Up}_{\mathbf{r}}$ ar Cretaceous-lower Paleogene strata in Bolivia and northwest Argentina. Bulletin of G 'ogical Society of America. 109 (6), 709-727.

Sobel, E.R., Hilley, G.E., Stre ‘ er, iM.R., 2003. Formation of internally drained contractional basins by aridity-limitec redrock incision. Journal of Geophysical Research. 108. doi:10.1029/2002Jb乞nเór3.

Stoertz, G.E., Ericksen, G.E., 1974. Geology of salars in northern chile. U.S. Geological Survey Professional Paper. 811, 65 p.

Tassara, A., 2005. Interaction between the Nazca and South American plates and formation of the Altiplano-Puna plateau: Review of a flexural analysis along the Andean margin $\left(15^{\circ}-\right.$ $\left.34^{\circ} \mathrm{S}\right)$. Tectonophysics. 399, 39-57. doi:10.1016/j.tecto.2004.12.014.

Teng, F.-Z., McDonough, W.F., Rudnick, R.L., Dalpé, C., Tomascak, P.B., Chapell, B.W., Gao, S., 2004. Lithium isotopic composition and concentration of the upper continental 
crust. Geochimica et Cosmochimica Acta. 68 (20), 4167-4178. doi: 10.1016/j.gca.2004.03.031.

Tremblay, M.M., Fox, M., Schmidt, J.L., Tripathy-Lang, A., Wielicki, M.M., Harrison, T.M., Zeitler, P.K., Shuster, D.L., 2015. Erosion in southern Tibet shut down at $\sim 10$ Ma due to enhanced rock uplift within the Himalaya. Proceedings of the National Academy of Sciences of the United States of America. 112. doi: 10.1073/pnas.1515652112.

Turner, J.C., 1959. Estratigrafía del cordón de Escaya y de la Sierra de Rinconada (Jujuy). Revista de la Asociación Geológica Argentina. 13 (1-2), 15-29.

Vandervoort, D., Jordan, T., Zeitler, P., Alonso, R.N., 19 J. nnronology of internal drainage development and uplift, southern Puna plateau, Argc ntina Central Andes. Geology. 23, 145-148. doi:10.1130/0091-7613(1995)023<0145·CL.DDA>2.3.CO;2.

Vásquez, C., Ortíz, C., Suárez, F., Muñoz, J.F , ¿’11. Modeling flow and reactive transport to explain mineral zoning in the Atacar. ${ }^{\text {s } s ~ a l t ~ f l a t ~ a q u i f e r, ~ C h i l e . ~ J o u r n a l ~ o f ~ H y d r o l o g y . ~ 490, ~}$ $114-125$

Vila, T., 1975. Geología de los danć ${ }^{i^{+}}$os salinos andinos, Provincia de Antofagasta, Chile. Revista Geológica de Chile. ?, 41-55.

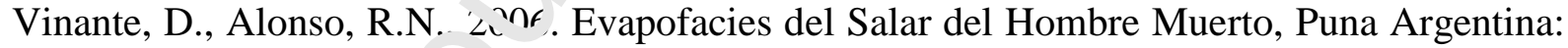
distribución y génesı nevista de la Asociación Geológica Argentina. 61 (2), 286-297.

Vine, J.D., 1976. Lithium Resources and Requirements by the Year 2000. U.S. Geological Survey Professional Paper. 1005, 169 p.

Warren, J.K., 2010. Evaporites through time: Tectonic, climatic and eustatic controls in marine and non-marine deposits. Earth-Science Reviews. 98, 217-268. doi:10.1016/j.earscirev.2009.11.004.

Weissman, G.S., Hartley, A.J., Scuderi, L.A., Nichols, G.J., Owen, A., Wright, S., Felicia, A.L., Holland, F., Anaya, F.M.L., 2015. Fluvial geomorphic elements in modern 
sedimentary basins and their potential preservation in the rock record: A review. Geomorphology. 250, 187-219. doi:10.1016/j.geomorph.2015.09.005.

Whitman, D., Isacks, B.L., Kay, S.M., 1996. Lithospheric structure and along-strike segmentation of the Central Andean Plateau: seismic Q, magmatism, flexure, topography and tectonics. Tectonophysics. 259 (1-3), 29-40. doi:10.1016/0040-1951(95)00130-1.

Yu, J.Q., Gao, C.L., Cheng, A.Y., Liu, Y., Zhang, Y., He, X.H., 2013. Geomorphic, hydroclimatic and hydrothermal controls on the formation of lithium brine deposits in the Qaidam Basin, northern Tibetan Plateau, China. Ore Genlogy Reviews. 50, 171-183. doi:10.1016/j.oregeorev.2012.11.001.

Zheng, M., Liu, X., 2009. Hydrochemistry of Salt Lakes ` $f$ the Qinghai-Tibet Plateau, China. Aquatic Geochemistry. 15, 293-320. doi:10.1007/•1し 98-008-9055-y.

Table 1. Altitude and comparative areal sur aces of Andean salt pans and of their endorheic basin catchments.

\begin{tabular}{clrrr}
\hline $\begin{array}{c}\mathrm{N}^{\circ} \\
(\text { Fig. } 1)\end{array}$ & Salt pan & $\begin{array}{c}\text { Altitude } \\
(\mathrm{m} \text { asl })\end{array}$ & $\begin{array}{r}\text { Salt pan surface } \\
\left(\mathrm{km}^{2}\right)\end{array}$ & $\begin{array}{r}\text { Basin surface } \\
\left(\mathrm{km}^{2}\right)\end{array}$ \\
\hline 1 & Surire & 4,260 & 144 & 574 \\
2 & Coipasa & 3,656 & 1,650 & 29,817 \\
3 & Uyuni & 3,633 & 10,000 & 45,239 \\
4 & Empexa & 3,725 & 402 & 2,111 \\
5 & Huasco & 3,778 & 51 & 1,572 \\
6 & Coposa & 3,730 & 85 & 1,116 \\
7 & Michincha & 4,130 & 25 & 282 \\
8 & Alconcha & 4,250 & 4 & 128 \\
9 & Carcote & 3,690 & 108 & 561 \\
10 & Ascotan & 3,716 & 243 & 1,757 \\
11 & Pastos Grandes (Altiplano) & 4,437 & 124 & 660 \\
12 & Atacama & 2,300 & 3,000 & 18,100 \\
13 & El Tara & 4,330 & 48 & 2,035
\end{tabular}




\begin{tabular}{|c|c|c|c|c|}
\hline 14 & Aguas Calientes Norte o 1 & 4,280 & 15 & 281 \\
\hline 15 & Pujsa & 4,500 & 18 & 634 \\
\hline 16 & Loyoques o Quisquiro & 4,150 & 80 & 676 \\
\hline 17 & Aguas Calientes Centro o 2 & 4,200 & 134 & 1,168 \\
\hline 18 & El Laco & 4,250 & 16 & 306 \\
\hline 19 & Aguas Calientes Sur o 3 & 3,950 & 46 & 476 \\
\hline 20 & Capur & 3,950 & 27 & 137 \\
\hline 21 & Imilac & 2,949 & 10 & 189 \\
\hline 22 & Punta Negra & 2,945 & 250 & 4,253 \\
\hline 23 & Aguas Calientes Sur Sur o 4 & 3,665 & 20 & 656 \\
\hline 24 & Pajanoles & 3,537 & 104 & 1,984 \\
\hline 25 & La Azufrera & 3,580 & 3 & 214 \\
\hline 26 & Gorbea & 3,950 & 27 & 324 \\
\hline 27 & Ignorados & 4,250 & 1 & 38 \\
\hline 28 & Agua Amarga & $3,55^{\prime}$ & 23 & 863 \\
\hline 29 & Aguilar & 3220 & 71 & 589 \\
\hline 30 & La Isla & $-99^{\circ} 0$ & 152 & 858 \\
\hline 31 & Los Infieles & 3,520 & 7 & 293 \\
\hline 32 & Las Parinas & 3,987 & 40 & 676 \\
\hline 33 & Salar Grande & 3,950 & 29 & 867 \\
\hline 34 & Pedernales & 3,370 & 335 & 3,620 \\
\hline 35 & Salar de la Laguna & 3,494 & 1 & 400 \\
\hline 36 & La Piedra Parada & 4,150 & 28 & 388 \\
\hline 37 & Wheelwright & 4,220 & 6 & 466 \\
\hline 38 & Maricunga & 3,760 & 145 & 3,045 \\
\hline 39 & Incahuasi & 3,269 & 18 & 1,620 \\
\hline 40 & Antofalla-Botijuelas & 3,330 & 655 & 9,259 \\
\hline 41 & Río Grande & 3,668 & 56 & 1,155 \\
\hline 42 & Arizaro & 3,474 & 1,708 & 7,508 \\
\hline 43 & Hombre Muerto & 3,970 & 300 & 3,881 \\
\hline 44 & Diablillos & 4,032 & 4 & 481 \\
\hline 45 & Ratones & 3,822 & 3 & 605 \\
\hline 46 & Centenario & 3,816 & 7 & 1,044 \\
\hline 47 & Pocitos-Quirón & 3,663 & 450 & 2,969 \\
\hline 48 & Pozuelos & 3,663 & 75 & 367 \\
\hline 49 & Pastos Grandes (Puna) & 3,780 & 27 & 1,752 \\
\hline
\end{tabular}




\begin{tabular}{llrrr}
50 & Rincón & 3,725 & 250 & 3,017 \\
51 & Cauchari & 3,903 & 80 & 2,557 \\
52 & Olaroz & 3,903 & 130 & 2,519 \\
53 & Jama & 4,080 & 25 & 1,500 \\
54 & Salinas Granes & 3,410 & 280 & 5,529 \\
55 & Guayatayoc & 3,400 & 140 & 11,805 \\
\hline
\end{tabular}

Table 2. Chemical composition of brines from Andean salt pans. Hydrochemical data of the Altiplano salars correspond to values reported by Risacher a.r. Fritz (1991), excepting for samples Uyu0, C0, EMP, and PGB that are from Ericksen anr. Sa' as (1987). Summarized data for the Puna de Atacama salars follow Risacher et al. (1's?' summarized by COCHILCO, 2013), excepting for samples LAC0, SUR0, HCO0, A $\leq \mathrm{C} 0$, ATA0, ATAdo, and AZU0 that are from Ericksen and Salas (1987). Brine chemi ry if the Puna salt pans follows data reported by López Steinmetz (2017), López Steinmıtz eı al. (2018), and López Steinmetz et al. (2020a), excepting for samples CE0, HMC, i' in, AR0, PC0, RI0, and RG0 that are from Ericksen and Salas (1987). TDS in $\mathrm{g} \mathrm{L}^{-1}$, en dinıg concentrations in $\mathrm{mg} \mathrm{L}^{-1}$.

\begin{tabular}{|c|c|c|c|c|c|c|c|c|c|c|c|}
\hline & $\mathrm{g} \mathrm{L}^{-1}$ & & & & & $\begin{array}{l}m g \\
\mathrm{~L}^{-1}\end{array}$ & & & & & \\
\hline \multicolumn{12}{|l|}{ UYUNI } \\
\hline sample & TDS & $\mathrm{Ta}_{\mathrm{a}}$ & $\mathrm{Mg}$ & $\mathrm{Na}$ & $\mathrm{K}$ & $\mathrm{Li}$ & $\mathrm{Cl}$ & $\mathrm{SO} 4$ & $\begin{array}{r}\mathrm{CO} \\
3\end{array}$ & $\begin{array}{c}\mathrm{HC} \\
\mathrm{O} 3\end{array}$ & B \\
\hline uyu0 & 351 & ¿ó1 & $\begin{array}{r}11,8 \\
00\end{array}$ & $\begin{array}{r}94,90 \\
0\end{array}$ & $\begin{array}{r}13,50 \\
0\end{array}$ & 700 & $\begin{array}{r}191,8 \\
00\end{array}$ & $\begin{array}{r}13,20 \\
0\end{array}$ & - & 592 & $\begin{array}{r}1,13 \\
6\end{array}$ \\
\hline UA15 & & 545 & $\begin{array}{r}7,78 \\
0\end{array}$ & $\begin{array}{r}107,0 \\
00\end{array}$ & 9,380 & 412 & $\begin{array}{r}190,0 \\
00\end{array}$ & 9,550 & - & - & 302 \\
\hline UA80 & 122 & 310 & $\begin{array}{r}16,1 \\
00\end{array}$ & $\begin{array}{r}91,80 \\
0\end{array}$ & $\begin{array}{r}17,60 \\
0\end{array}$ & 770 & $\begin{array}{r}190,0 \\
00\end{array}$ & $\begin{array}{r}23,00 \\
0\end{array}$ & - & - & 669 \\
\hline UA200 & 123 & 316 & $\begin{array}{r}16,6 \\
00\end{array}$ & $\begin{array}{r}90,30 \\
0\end{array}$ & $\begin{array}{r}17,30 \\
0\end{array}$ & 812 & $\begin{array}{r}191,0 \\
00\end{array}$ & $\begin{array}{r}22,40 \\
0\end{array}$ & - & - & 655 \\
\hline UA400 & 123 & 327 & $\begin{array}{r}16,8 \\
00\end{array}$ & $\begin{array}{r}94,90 \\
0\end{array}$ & $\begin{array}{r}17,40 \\
0\end{array}$ & 812 & $\begin{array}{r}196,0 \\
00\end{array}$ & $\begin{array}{r}22,50 \\
0\end{array}$ & - & - & 657 \\
\hline UA600 & 123 & 315 & $\begin{array}{r}17,3 \\
00\end{array}$ & $\begin{array}{r}91,40 \\
0\end{array}$ & $\begin{array}{r}17,60 \\
0\end{array}$ & 826 & $\begin{array}{r}192,0 \\
00\end{array}$ & $\begin{array}{r}24,40 \\
0\end{array}$ & - & - & 668 \\
\hline UB10 & 125 & 137 & $\begin{array}{r}38,4 \\
00\end{array}$ & $\begin{array}{r}57,00 \\
0\end{array}$ & $\begin{array}{r}29,70 \\
0\end{array}$ & $\begin{array}{r}1,78 \\
0\end{array}$ & $\begin{array}{r}200,0 \\
00\end{array}$ & $\begin{array}{r}43,90 \\
0\end{array}$ & - & - & $\begin{array}{r}1,71 \\
0\end{array}$ \\
\hline UB100 & 224 & 149 & $\begin{array}{r}51,0 \\
00\end{array}$ & $\begin{array}{r}36,10 \\
0\end{array}$ & $\begin{array}{r}19,40 \\
0\end{array}$ & $\begin{array}{r}2,56 \\
0\end{array}$ & $\begin{array}{r}210,0 \\
00\end{array}$ & $\begin{array}{r}32,80 \\
0\end{array}$ & - & - & $\begin{array}{r}2,02 \\
0\end{array}$ \\
\hline UB250 & 125 & 50 & $\begin{array}{r}55,4 \\
00\end{array}$ & $\begin{array}{r}28,80 \\
0\end{array}$ & $\begin{array}{r}19,40 \\
0\end{array}$ & $\begin{array}{r}2,79 \\
0\end{array}$ & $\begin{array}{r}214,0 \\
00\end{array}$ & $\begin{array}{r}34,30 \\
0\end{array}$ & - & - & $\begin{array}{r}2,16 \\
0\end{array}$ \\
\hline UB400 & 125 & 50 & $\begin{array}{r}55,9 \\
00\end{array}$ & $\begin{array}{r}29,20 \\
0\end{array}$ & $\begin{array}{r}19,70 \\
0\end{array}$ & $\begin{array}{r}2,83 \\
0\end{array}$ & $\begin{array}{r}215,0 \\
00\end{array}$ & $\begin{array}{r}34,60 \\
0\end{array}$ & - & - & $\begin{array}{r}2,19 \\
0\end{array}$ \\
\hline
\end{tabular}




\begin{tabular}{|c|c|c|c|c|c|c|c|c|c|c|}
\hline UC5 & 123 & 233 & $\begin{array}{r}32,3 \\
00\end{array}$ & $\begin{array}{r}68,30 \\
0\end{array}$ & $\begin{array}{r}20,10 \\
0\end{array}$ & $\begin{array}{r}1,46 \\
0\end{array}$ & $\begin{array}{r}194,0 \\
00\end{array}$ & $\begin{array}{r}30,70 \\
0\end{array}$ & - & \\
\hline UC100 & 122 & 268 & $\begin{array}{r}19,2 \\
00\end{array}$ & $\begin{array}{r}88,60 \\
0\end{array}$ & $\begin{array}{r}19,00 \\
0\end{array}$ & 888 & $\begin{array}{r}190,0 \\
00\end{array}$ & $\begin{array}{r}25,60 \\
0\end{array}$ & - & \\
\hline UC250 & 122 & 269 & $\begin{array}{r}19,3 \\
00\end{array}$ & $\begin{array}{r}88,60 \\
0\end{array}$ & $\begin{array}{r}18,60 \\
0\end{array}$ & 868 & $\begin{array}{r}192,0 \\
00\end{array}$ & $\begin{array}{r}26,20 \\
0\end{array}$ & - & \\
\hline UC400 & 122 & 269 & $\begin{array}{r}19,2 \\
00\end{array}$ & $\begin{array}{r}89,20 \\
0\end{array}$ & $\begin{array}{r}18,80 \\
0\end{array}$ & 881 & $\begin{array}{r}191,0 \\
00\end{array}$ & $\begin{array}{r}26,70 \\
0\end{array}$ & - & - \\
\hline UD10 & 122 & 208 & $\begin{array}{r}30,6 \\
00\end{array}$ & $\begin{array}{r}66,20 \\
0\end{array}$ & $\begin{array}{r}26,70 \\
0\end{array}$ & $\begin{array}{r}1,31 \\
0\end{array}$ & $\begin{array}{r}197,0 \\
00\end{array}$ & $\begin{array}{r}30,80 \\
0\end{array}$ & - & \\
\hline UD100 & 122 & 317 & $\begin{array}{r}19,9 \\
00\end{array}$ & $\begin{array}{r}85,10 \\
0\end{array}$ & $\begin{array}{r}21,60 \\
0\end{array}$ & 888 & $\begin{array}{r}194,0 \\
00\end{array}$ & $\begin{array}{r}22,60 \\
0\end{array}$ & - & - \\
\hline UD250 & 122 & 293 & $\begin{array}{r}19,2 \\
00\end{array}$ & $\begin{array}{r}87,60 \\
0\end{array}$ & $\begin{array}{r}20,30 \\
0\end{array}$ & 819 & $\begin{array}{r}193,0 \\
00\end{array}$ & $\begin{array}{r}25,30 \\
0\end{array}$ & - & - \\
\hline UD400 & 122 & 294 & $\begin{array}{r}19,3 \\
00\end{array}$ & $\begin{array}{r}88,10 \\
0\end{array}$ & $\begin{array}{r}20,30 \\
0\end{array}$ & 819 & $\begin{array}{r}191,0 \\
00\end{array}$ & $\begin{array}{r}25,40 \\
0\end{array}$ & - & - \\
\hline UE5 & 123 & 294 & $\begin{array}{r}24,5 \\
00\end{array}$ & $\begin{array}{r}78,70 \\
0\end{array}$ & $\begin{array}{r}22,60 \\
0\end{array}$ & 70 & $\begin{array}{r}175,0 \\
00\end{array}$ & $\begin{array}{r}27,70 \\
0\end{array}$ & - & - \\
\hline UE100 & 122 & 269 & $\begin{array}{r}17,6 \\
00\end{array}$ & $\begin{array}{r}92,00 \\
0\end{array}$ & $\begin{array}{r}19,30 \\
0\end{array}$ & 708 & $\begin{array}{r}190,0 \\
00\end{array}$ & $\begin{array}{r}29,40 \\
0\end{array}$ & - & - \\
\hline UE250 & 122 & 269 & $\begin{array}{r}17,4 \\
00\end{array}$ & $\begin{array}{r}92,20 \\
0\end{array}$ & $19, ? \frac{?}{0}$ & 708 & $\begin{array}{r}190,0 \\
00\end{array}$ & $\begin{array}{r}28,60 \\
0\end{array}$ & - & - \\
\hline UE400 & 122 & 269 & $\begin{array}{r}17,3 \\
00\end{array}$ & $\begin{array}{r}92,00 \\
0\end{array}$ & $\begin{array}{r}19,30 \\
0\end{array}$ & 708 & $\begin{array}{r}189,0 \\
00\end{array}$ & $\begin{array}{r}28,10 \\
0\end{array}$ & - & - \\
\hline UF30 & 121 & 654 & $\begin{array}{r}7,39 \\
0\end{array}$ & $\begin{array}{r}109,0 \\
\mathrm{C}^{2}\end{array}$ &,- 430 & 339 & $\begin{array}{r}190,0 \\
00\end{array}$ & $\begin{array}{r}10,30 \\
0\end{array}$ & - & - \\
\hline UF110 & 121 & 618 & $\begin{array}{r}7,6 ? \\
0\end{array}$ & $\begin{array}{r}1,8,0 \\
00\end{array}$ & 7,510 & 339 & $\begin{array}{r}190,0 \\
00\end{array}$ & $\begin{array}{r}10,70 \\
0\end{array}$ & - & - \\
\hline UG15 & 121 & 834 & $\begin{array}{r}, 78 \\
0\end{array}$ & $\begin{array}{r}112,0 \\
00\end{array}$ & 5,790 & 254 & $\begin{array}{r}190,0 \\
00\end{array}$ & 8,200 & - & - \\
\hline UG95 & 121 & 738 & 635 & $\begin{array}{r}110,0 \\
00\end{array}$ & 6,180 & 266 & $\begin{array}{r}191,0 \\
00\end{array}$ & 9,140 & - & - \\
\hline UG270 & 121 & 166 & $\begin{array}{r}6,97 \\
0\end{array}$ & $\begin{array}{r}109,0 \\
00\end{array}$ & 6,800 & 303 & $\begin{array}{r}190,0 \\
00\end{array}$ & 9,790 & - & - \\
\hline UH10 & 12. & 7,0 & $\begin{array}{r}6,93 \\
0\end{array}$ & $\begin{array}{r}109,0 \\
00\end{array}$ & 7,190 & 315 & $\begin{array}{r}191,0 \\
00\end{array}$ & 8,960 & - & - \\
\hline UH100 & & 666 & $\begin{array}{r}7,85 \\
0\end{array}$ & $\begin{array}{r}107,0 \\
00\end{array}$ & 7,940 & 351 & $\begin{array}{r}190,0 \\
00\end{array}$ & $\begin{array}{r}10,10 \\
0\end{array}$ & - & - \\
\hline UH300 & 122 & 437 & $\begin{array}{r}11,5 \\
00\end{array}$ & $\begin{array}{r}100,0 \\
00\end{array}$ & $\begin{array}{r}10,30 \\
0\end{array}$ & 463 & $\begin{array}{r}189,0 \\
00\end{array}$ & $\begin{array}{r}18,70 \\
0\end{array}$ & - & - \\
\hline UH500 & 122 & 401 & $\begin{array}{r}12,1 \\
00\end{array}$ & $\begin{array}{r}98,20 \\
0\end{array}$ & $\begin{array}{r}10,50 \\
0\end{array}$ & 488 & $\begin{array}{r}189,0 \\
00\end{array}$ & $\begin{array}{r}20,30 \\
0\end{array}$ & - & - \\
\hline UH700 & 122 & 391 & $\begin{array}{r}12,1 \\
00\end{array}$ & $\begin{array}{r}99,40 \\
0\end{array}$ & $\begin{array}{r}10,80 \\
0\end{array}$ & 489 & $\begin{array}{r}190,0 \\
00\end{array}$ & $\begin{array}{r}20,70 \\
0\end{array}$ & - & - \\
\hline UH900 & 122 & 367 & $\begin{array}{r}12,6 \\
00\end{array}$ & $\begin{array}{r}100,0 \\
00\end{array}$ & $\begin{array}{r}11,20 \\
0\end{array}$ & 513 & $\begin{array}{r}188,0 \\
00\end{array}$ & $\begin{array}{r}22,20 \\
0\end{array}$ & - & - \\
\hline UI15 & 121 & 714 & $\begin{array}{r}6,66 \\
0\end{array}$ & $\begin{array}{r}109,0 \\
00\end{array}$ & 7,120 & 303 & $\begin{array}{r}190,0 \\
00\end{array}$ & 9,370 & - & - \\
\hline UI100 & 121 & 702 & $\begin{array}{r}6,63 \\
0\end{array}$ & $\begin{array}{r}106,0 \\
00\end{array}$ & 6,760 & 303 & $\begin{array}{r}189,0 \\
00\end{array}$ & 9,360 & - & - \\
\hline UI1000 & 121 & 569 & $\begin{array}{r}7,29 \\
0\end{array}$ & $\begin{array}{r}106,0 \\
00\end{array}$ & 7,590 & 303 & $\begin{array}{r}189,0 \\
00\end{array}$ & $\begin{array}{r}14,10 \\
0\end{array}$ & - & - \\
\hline UJ15 & 121 & 786 & $\begin{array}{r}7,00 \\
0\end{array}$ & $\begin{array}{r}107,0 \\
00\end{array}$ & 7,590 & 339 & $\begin{array}{r}190,0 \\
00\end{array}$ & 8,930 & - & \\
\hline UJ100 & 122 & 521 & 11,1 & 100,0 & 11,00 & 584 & 191,0 & 14,20 & - & - \\
\hline
\end{tabular}




\begin{tabular}{|c|c|c|c|c|c|c|c|c|c|c|}
\hline UJ300 & 122 & 437 & $\begin{array}{r}12,8 \\
00\end{array}$ & $\begin{array}{r}95,90 \\
0\end{array}$ & $\begin{array}{r}12,00 \\
0\end{array}$ & 560 & $\begin{array}{r}189,0 \\
00\end{array}$ & $\begin{array}{r}18,10 \\
0\end{array}$ & - & 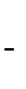 \\
\hline UJ700 & 122 & 391 & $\begin{array}{r}14,1 \\
00\end{array}$ & $\begin{array}{r}94,80 \\
0\end{array}$ & $\begin{array}{r}12,40 \\
0\end{array}$ & 575 & $\begin{array}{r}187,0 \\
00\end{array}$ & $\begin{array}{r}24,10 \\
0\end{array}$ & - & \\
\hline UK10 & 122 & 622 & $\begin{array}{r}8,82 \\
0\end{array}$ & $\begin{array}{r}103,0 \\
00\end{array}$ & 8,880 & 413 & $\begin{array}{r}191,0 \\
00\end{array}$ & $\begin{array}{r}11,00 \\
0\end{array}$ & - & - \\
\hline UK100 & 122 & 417 & $\begin{array}{r}14,7 \\
00\end{array}$ & $\begin{array}{r}94,30 \\
0\end{array}$ & $\begin{array}{r}14,60 \\
0\end{array}$ & 685 & $\begin{array}{r}192,0 \\
00\end{array}$ & $\begin{array}{r}18,70 \\
0\end{array}$ & - & - \\
\hline UK200 & 123 & 319 & $\begin{array}{r}15,6 \\
00\end{array}$ & $\begin{array}{r}93,80 \\
0\end{array}$ & $\begin{array}{r}14,40 \\
0\end{array}$ & 688 & $\begin{array}{r}190,0 \\
00\end{array}$ & $\begin{array}{r}25,10 \\
0\end{array}$ & - & - \\
\hline UK400 & 123 & 295 & $\begin{array}{r}15,9 \\
00\end{array}$ & $\begin{array}{r}93,80 \\
0\end{array}$ & $\begin{array}{r}24,00 \\
0\end{array}$ & 688 & $\begin{array}{r}187,0 \\
00\end{array}$ & $\begin{array}{r}28,50 \\
0\end{array}$ & - & - \\
\hline UL20 & 122 & 401 & $\begin{array}{r}17,5 \\
00\end{array}$ & $\begin{array}{r}87,60 \\
0\end{array}$ & $\begin{array}{r}19,50 \\
0\end{array}$ & 805 & $\begin{array}{r}194,0 \\
00\end{array}$ & $\begin{array}{r}16,00 \\
0\end{array}$ & - & - \\
\hline UL100 & 122 & 390 & $\begin{array}{r}17,1 \\
00\end{array}$ & $\begin{array}{r}87,90 \\
0\end{array}$ & $\begin{array}{r}17,80 \\
0\end{array}$ & 805 & $\begin{array}{r}1: 50 \\
00\end{array}$ & $\begin{array}{r}16,30 \\
0\end{array}$ & - & - \\
\hline UL250 & 122 & 340 & $\begin{array}{r}18,9 \\
00\end{array}$ & $\begin{array}{r}82,80 \\
0\end{array}$ & $\begin{array}{r}17,40 \\
0\end{array}$ & 540 & $\begin{array}{r}-90,0 \\
00\end{array}$ & $\begin{array}{r}18,10 \\
0\end{array}$ & - & - \\
\hline UM17 & 121 & 638 & $\begin{array}{r}6,42 \\
0\end{array}$ & $\begin{array}{r}109,0 \\
00\end{array}$ & 7,160 & 977 & $\begin{array}{r}189,0 \\
00\end{array}$ & 7,870 & - & - \\
\hline UM100 & 122 & 425 & $\begin{array}{r}13,5 \\
00\end{array}$ & $\begin{array}{r}91,00 \\
0\end{array}$ & $\begin{array}{r}12,10 \\
0\end{array}$ & 559 & $\begin{array}{r}191,0 \\
00\end{array}$ & $\begin{array}{r}15,10 \\
0\end{array}$ & - & - \\
\hline UM400 & 122 & 269 & $\begin{array}{r}16,3 \\
00\end{array}$ & $\begin{array}{r}92,50 \\
0\end{array}$ & $\begin{array}{r}3,90 \\
0\end{array}$ & 672 & $\begin{array}{r}187,0 \\
00\end{array}$ & $\begin{array}{r}26,00 \\
0\end{array}$ & - & - \\
\hline UN16 & 122 & 354 & $\begin{array}{r}19,1 \\
0 \text { C }\end{array}$ & $\begin{array}{r}-5,0{ }^{7} \\
0\end{array}$ & $\begin{array}{r}18,00 \\
0\end{array}$ & 868 & $\begin{array}{r}194,0 \\
00\end{array}$ & $\begin{array}{r}19,10 \\
0\end{array}$ & - & - \\
\hline UN100 & 122 & 354 & $\begin{array}{r}19,4 \\
7)\end{array}$ & $\begin{array}{r}5.10 \\
0\end{array}$ & $\begin{array}{r}19,40 \\
0\end{array}$ & 916 & $\begin{array}{r}193,0 \\
00\end{array}$ & $\begin{array}{r}19,30 \\
0\end{array}$ & - & - \\
\hline UN300 & 123 & 245 & $\begin{array}{r}-17 \\
0\end{array}$ & $\begin{array}{r}80,50 \\
0\end{array}$ & $\begin{array}{r}19,40 \\
0\end{array}$ & 979 & $\begin{array}{r}192,0 \\
00\end{array}$ & $\begin{array}{r}24,80 \\
0\end{array}$ & - & - \\
\hline UO9 & 121 & $5 ? 3$ & $\begin{array}{r}10,5 \\
00\end{array}$ & $\begin{array}{r}103,0 \\
00\end{array}$ & $\begin{array}{r}10,80 \\
0\end{array}$ & 471 & $\begin{array}{r}191,0 \\
00\end{array}$ & $\begin{array}{r}11,60 \\
0\end{array}$ & - & - \\
\hline UO100 & 122 & $34 i$ & $\begin{array}{r}17,8 \\
00\end{array}$ & $\begin{array}{r}89,20 \\
0\end{array}$ & $\begin{array}{r}16,60 \\
0\end{array}$ & 784 & $\begin{array}{r}190,0 \\
00\end{array}$ & $\begin{array}{r}20,00 \\
0\end{array}$ & - & - \\
\hline UO500 & & 234 & $\begin{array}{r}21,8 \\
00\end{array}$ & $\begin{array}{r}88,60 \\
0\end{array}$ & $\begin{array}{r}18,30 \\
0\end{array}$ & 937 & $\begin{array}{r}190,0 \\
00\end{array}$ & $\begin{array}{r}36,00 \\
0\end{array}$ & - & - \\
\hline UP17 & $1 ? 2$ & 378 & $\begin{array}{r}16,7 \\
00\end{array}$ & $\begin{array}{r}82,60 \\
0\end{array}$ & $\begin{array}{r}16,30 \\
0\end{array}$ & 756 & $\begin{array}{r}192,0 \\
00\end{array}$ & $\begin{array}{r}17,10 \\
0\end{array}$ & - & - \\
\hline UP100 & 122 & 305 & $\begin{array}{r}20,6 \\
00\end{array}$ & $\begin{array}{r}78,20 \\
0\end{array}$ & $\begin{array}{r}19,40 \\
0\end{array}$ & 930 & $\begin{array}{r}193,0 \\
00\end{array}$ & $\begin{array}{r}21,00 \\
0\end{array}$ & - & - \\
\hline UP500 & 123 & 282 & $\begin{array}{r}21,3 \\
00\end{array}$ & $\begin{array}{r}77,30 \\
0\end{array}$ & $\begin{array}{r}19,00 \\
0\end{array}$ & 944 & $\begin{array}{r}193,0 \\
00\end{array}$ & $\begin{array}{r}24,00 \\
0\end{array}$ & - & - \\
\hline UQ17 & 120 & 577 & $\begin{array}{r}7,29 \\
0\end{array}$ & $\begin{array}{r}111,0 \\
00\end{array}$ & 7,510 & 313 & $\begin{array}{r}190,0 \\
00\end{array}$ & 9,020 & - & - \\
\hline UQ100 & 121 & 533 & $\begin{array}{r}9,40 \\
0\end{array}$ & $\begin{array}{r}104,0 \\
00\end{array}$ & 9,460 & 399 & $\begin{array}{r}190,0 \\
00\end{array}$ & $\begin{array}{r}10,90 \\
0\end{array}$ & - & - \\
\hline UQ450 & 121 & 545 & $\begin{array}{r}9,96 \\
0\end{array}$ & $\begin{array}{r}101,0 \\
00\end{array}$ & 9,660 & 411 & $\begin{array}{r}192,0 \\
00\end{array}$ & $\begin{array}{r}11,70 \\
0\end{array}$ & - & - \\
\hline UQ800 & 121 & 509 & $\begin{array}{r}10,4 \\
00\end{array}$ & $\begin{array}{r}98,20 \\
0\end{array}$ & $\begin{array}{r}10,00 \\
0\end{array}$ & 424 & $\begin{array}{r}190,0 \\
00\end{array}$ & $\begin{array}{r}12,80 \\
0\end{array}$ & - & \\
\hline UR15 & 121 & 457 & $\begin{array}{r}5,69 \\
0\end{array}$ & $\begin{array}{r}112,0 \\
00\end{array}$ & 5,470 & 217 & $\begin{array}{r}190,0 \\
00\end{array}$ & 8,090 & - & - \\
\hline UR100 & 121 & 565 & $\begin{array}{r}8,09 \\
0\end{array}$ & $\begin{array}{r}107,0 \\
00\end{array}$ & 7,980 & 314 & $\begin{array}{r}190,0 \\
00\end{array}$ & $\begin{array}{r}10,80 \\
0\end{array}$ & - & - \\
\hline
\end{tabular}




\begin{tabular}{|c|c|c|c|c|c|c|c|c|c|c|}
\hline UR450 & 121 & 577 & $\begin{array}{r}8,31 \\
0\end{array}$ & $\begin{array}{r}106,0 \\
00\end{array}$ & 8,330 & 338 & $\begin{array}{r}188,0 \\
00\end{array}$ & $\begin{array}{r}11,20 \\
0\end{array}$ & - & - \\
\hline UR800 & 122 & 413 & $\begin{array}{r}12,5 \\
00\end{array}$ & $\begin{array}{r}102,0 \\
00\end{array}$ & $\begin{array}{r}11,30 \\
0\end{array}$ & 413 & $\begin{array}{r}187,0 \\
00\end{array}$ & $\begin{array}{r}19,70 \\
0\end{array}$ & - & - \\
\hline US9 & 120 & 577 & $\begin{array}{r}6,34 \\
0\end{array}$ & $\begin{array}{r}108,0 \\
00\end{array}$ & 6,650 & 276 & $\begin{array}{r}190,0 \\
00\end{array}$ & 8,870 & - & - \\
\hline US100 & 121 & 606 & $\begin{array}{r}7,63 \\
0\end{array}$ & $\begin{array}{r}106,0 \\
00\end{array}$ & 7,980 & 314 & $\begin{array}{r}192,0 \\
00\end{array}$ & $\begin{array}{r}10,50 \\
0\end{array}$ & - & - \\
\hline US450 & 122 & 401 & $\begin{array}{r}11,2 \\
00\end{array}$ & $\begin{array}{r}99,40 \\
0\end{array}$ & $\begin{array}{r}12,00 \\
0\end{array}$ & 389 & $\begin{array}{r}187,0 \\
00\end{array}$ & $\begin{array}{r}21,60 \\
0\end{array}$ & - & - \\
\hline US00 & 122 & 294 & $\begin{array}{r}13,5 \\
00\end{array}$ & $\begin{array}{r}101,0 \\
00\end{array}$ & $\begin{array}{r}14,00 \\
0\end{array}$ & 465 & $\begin{array}{r}186,0 \\
00\end{array}$ & $\begin{array}{r}30,30 \\
0\end{array}$ & - & - \\
\hline UT15 & 121 & 642 & $\begin{array}{r}6,83 \\
0\end{array}$ & $\begin{array}{r}109,0 \\
00\end{array}$ & 7,470 & 278 & $\begin{array}{r}190,0 \\
00\end{array}$ & $\begin{array}{r}10,10 \\
0\end{array}$ & - & - \\
\hline UT100 & 120 & 626 & $\begin{array}{r}6,97 \\
0\end{array}$ & $\begin{array}{r}107,0 \\
00\end{array}$ & 7,350 & 277 & $\begin{array}{r}189,0 \\
00\end{array}$ & $\begin{array}{r}10,20 \\
0\end{array}$ & - & - \\
\hline UT450 & 121 & 630 & $\begin{array}{r}6,90 \\
0\end{array}$ & $\begin{array}{r}106,0 \\
00\end{array}$ & 7,230 & $26 c$ & $\begin{array}{r}1^{7} 0,0 \\
00\end{array}$ & $\begin{array}{r}10,20 \\
0\end{array}$ & - & - \\
\hline UT800 & 121 & 533 & $\begin{array}{r}8,31 \\
0\end{array}$ & $\begin{array}{r}106,0 \\
00\end{array}$ & 8,800 & $\therefore 7$ & $\begin{array}{r}189,0 \\
00\end{array}$ & $\begin{array}{r}13,00 \\
0\end{array}$ & - & - \\
\hline UU20 & 121 & 565 & $\begin{array}{r}10,3 \\
00\end{array}$ & $\begin{array}{r}106,0 \\
00\end{array}$ & $6,6>0$ & 350 & $\begin{array}{r}188,0 \\
00\end{array}$ & $\begin{array}{r}12,30 \\
0\end{array}$ & - & - \\
\hline UU350 & 120 & 533 & $\begin{array}{r}8,97 \\
0\end{array}$ & $\begin{array}{r}103,0 \\
00\end{array}$ & 7,J90 & 291 & $\begin{array}{r}191,0 \\
00\end{array}$ & $\begin{array}{r}11,80 \\
0\end{array}$ & - & - \\
\hline UU700 & 121 & 388 & $\begin{array}{r}10,8 \\
00\end{array}$ & $\begin{array}{r}107,0 \\
\text { u? }\end{array}$ & ,, 580 & 316 & $\begin{array}{r}188,0 \\
00\end{array}$ & $\begin{array}{r}19,20 \\
0\end{array}$ & - & - \\
\hline UV10 & 121 & 630 & $\begin{array}{r}8,1^{\prime} \\
0\end{array}$ & $\begin{array}{r}1.0,0 \\
00\end{array}$ & 6,450 & 242 & $\begin{array}{r}191,0 \\
00\end{array}$ & $\begin{array}{r}10,10 \\
0\end{array}$ & - & - \\
\hline UV100 & 121 & 618 & $\begin{array}{r}0,72 \\
0\end{array}$ & $\begin{array}{r}110,0 \\
00\end{array}$ & 6,490 & 242 & $\begin{array}{r}190,0 \\
00\end{array}$ & $\begin{array}{r}10,60 \\
0\end{array}$ & - & - \\
\hline UV500 & 121 & 618 & $8 \mathrm{~J}$ & $\begin{array}{r}108,0 \\
00\end{array}$ & 6,370 & 242 & $\begin{array}{r}191,0 \\
00\end{array}$ & $\begin{array}{r}10,70 \\
0\end{array}$ & - & - \\
\hline UW22 & 123 & & $\begin{array}{r}27,7 \\
00\end{array}$ & $\begin{array}{r}69,90 \\
0\end{array}$ & $\begin{array}{r}22,80 \\
0\end{array}$ & $\begin{array}{r}1,03 \\
0\end{array}$ & $\begin{array}{r}200,0 \\
00\end{array}$ & $\begin{array}{r}18,80 \\
0\end{array}$ & - & 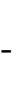 \\
\hline UW100 & & 4,3 & $\begin{array}{r}20,9 \\
00\end{array}$ & $\begin{array}{r}86,30 \\
0\end{array}$ & $\begin{array}{r}16,20 \\
0\end{array}$ & 784 & $\begin{array}{r}196,0 \\
00\end{array}$ & $\begin{array}{r}14,20 \\
0\end{array}$ & - & - \\
\hline UX90 & & 294 & $\begin{array}{r}28,9 \\
00\end{array}$ & $\begin{array}{r}72,00 \\
0\end{array}$ & $\begin{array}{r}17,70 \\
0\end{array}$ & $\begin{array}{r}1,13 \\
0\end{array}$ & $\begin{array}{r}195,0 \\
00\end{array}$ & $\begin{array}{r}22,60 \\
0\end{array}$ & - & - \\
\hline UX300 & $1 \angle 3$ & 307 & $\begin{array}{r}28,9 \\
00\end{array}$ & $\begin{array}{r}72,00 \\
0\end{array}$ & $\begin{array}{r}17,90 \\
0\end{array}$ & $\begin{array}{r}1,18 \\
0\end{array}$ & $\begin{array}{r}195,0 \\
00\end{array}$ & $\begin{array}{r}23,00 \\
0\end{array}$ & - & - \\
\hline UY16 & 121 & 726 & $\begin{array}{r}7,19 \\
0\end{array}$ & $\begin{array}{r}111,0 \\
00\end{array}$ & 6,330 & 254 & $\begin{array}{r}191,0 \\
00\end{array}$ & 8,690 & - & - \\
\hline UY100 & 121 & 581 & $\begin{array}{r}9,55 \\
0\end{array}$ & $\begin{array}{r}105,0 \\
00\end{array}$ & 8,130 & 340 & $\begin{array}{r}190,0 \\
00\end{array}$ & $\begin{array}{r}11,10 \\
0\end{array}$ & - & - \\
\hline UY300 & 122 & 354 & $\begin{array}{r}14,5 \\
00\end{array}$ & $\begin{array}{r}97,80 \\
0\end{array}$ & $\begin{array}{r}12,60 \\
0\end{array}$ & 500 & $\begin{array}{r}189,0 \\
00\end{array}$ & $\begin{array}{r}22,20 \\
0\end{array}$ & - & - \\
\hline UY600 & 122 & 316 & $\begin{array}{r}15,3 \\
00\end{array}$ & $\begin{array}{r}96,40 \\
0\end{array}$ & $\begin{array}{r}13,10 \\
0\end{array}$ & 511 & $\begin{array}{r}188,0 \\
00\end{array}$ & $\begin{array}{r}24,80 \\
0\end{array}$ & - & - \\
\hline UZ12 & 121 & 557 & $\begin{array}{r}8,89 \\
0\end{array}$ & $\begin{array}{r}101,0 \\
00\end{array}$ & 9,190 & 484 & $\begin{array}{r}191,0 \\
00\end{array}$ & 9,890 & - & - \\
\hline UZ100 & 122 & 413 & $\begin{array}{r}15,1 \\
00\end{array}$ & $\begin{array}{r}95,70 \\
0\end{array}$ & $\begin{array}{r}12,40 \\
0\end{array}$ & 536 & $\begin{array}{r}191,0 \\
00\end{array}$ & $\begin{array}{r}16,30 \\
0\end{array}$ & - & \\
\hline UZ450 & 122 & 354 & $\begin{array}{r}17,1 \\
00\end{array}$ & $\begin{array}{r}92,90 \\
0\end{array}$ & $\begin{array}{r}13,40 \\
0\end{array}$ & 599 & $\begin{array}{r}192,0 \\
00\end{array}$ & $\begin{array}{r}19,30 \\
0\end{array}$ & - & \\
\hline UZ800 & 122 & 342 & 17,0 & 91,10 & 13,30 & 598 & 190,0 & 19,50 & - & - \\
\hline
\end{tabular}


U112

U1400

U1800

U213

U2100

U2200

U2300

U2400

U2500

U2600

YA17

YA100

YB11

YB100

YB500

YC12

YC100

YD9

YD100

YD450

YD800

YE8

YE100

YE450

YE800

YF23

YF200

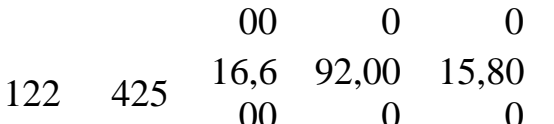

$123264 \quad 21,3 \quad 86,50 \quad 19,20$

$123 \quad 247 \quad 21,6 \quad 83,70 \quad 19,50$

\section{1}

$121 \quad 433$

$122 \quad 331$$$
122 \quad 307
$$

$\begin{array}{rrrrr}122 & 307 & 00 & 0 & 0 \\ & & 18,7 & 86,50 & 17,90\end{array}$

$\begin{array}{rrrrr}122 & 284 & 18,7 & 86,50 & 17,90 \\ & 00 & 0 & 0\end{array}$

$\begin{array}{llrrr}123 & 234 & 20,4 & 85,60 & 18,60\end{array}$

$\begin{array}{lrrrr}123 & 223 & 20,5 & 85,60 & 18,60\end{array}$

$\begin{array}{rrrrr}123 & 223 & 20,7 & 85,60 & 18,40 \\ & 00 & 0 & \mathrm{v}\end{array}$

$\begin{array}{rrrrr}121 & 577 & 9,53 & 102,0 & \left.12, ?^{\prime}\right) \\ & 0 & 00 & 0\end{array}$

$\begin{array}{rrrrr}121 & 449 & 12,2 & 95,90 & 3,60 \\ & 00 & 0 & 0\end{array}$

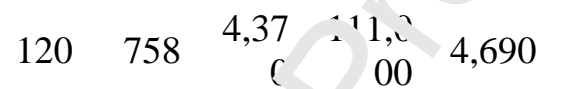

$\begin{array}{rrrrr}121 & 581 & 8,65 & 773,0 & 8,910 \\ & 0 & 00 & \end{array}$

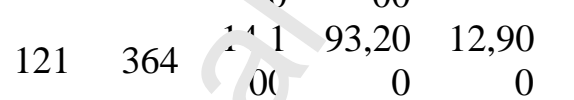

$120 \quad 6$ 6? $\quad \begin{array}{rrrr}3,04 & 112,0 & 3,860\end{array}$

120 Gis

(2) 158

$1 ? 1421$

$120 \quad 341$

$\begin{array}{rrrr}00 & 0 & 0\end{array}$

$\begin{array}{rrrrr}122 & 329 & 16,5 & 90,20 & 15,40 \\ & 00 & 0 & 0\end{array}$

$\begin{array}{rrrrr}121 & 662 & 5,30 & 110,0 & 5,750\end{array}$

$\begin{array}{rrrrr}121 & 400 & 12,4 & 95,90 & 12,60 \\ & 00 & 0 & 0\end{array}$

$\begin{array}{rrrrr}125 & 274 & 17,2 & 91,50 & 16,10 \\ & 00 & 0 & 0\end{array}$

$\begin{array}{rrrrr}123 & 269 & 16,9 & 89,50 & 15,80 \\ & 00 & 0 & 0\end{array}$

$120 \begin{array}{rrrrr}1,03 & 2,96 & 113,0 & 3,090 \\ & 0 & 0 & 00 & \end{array}$

$\begin{array}{rrrrrr}120 & 854 & 4,50 & 109,0 & 4,650 & 144\end{array}$
$00 \quad 0$

$196,0 \quad 17,00$

$00 \quad 0$

$197,0 \quad 29,50$

- 578

- 987

$\begin{array}{lll}193,0 & 31,70 \quad 1,04\end{array}$

$195,0 \quad 15,90$

$00 \quad 0$

$196,0 \quad 23,00$

$00 \quad 0$

$193,0 \quad 25,20$

$00 \quad 0$

$190,0 \quad 27,40$

$826 \quad 00 \quad 0$

$10^{7} .0 \quad 33,10$

$00 \quad 0$

$\therefore 69,0 \quad 34,10$

$00 \quad 0$

$187,0 \quad 34,10$

$00 \quad 0$

$192,0 \quad 10,10$

$00 \quad 0$

$191,0 \quad 13,70$

$\begin{array}{rrr}557 & 00 & 0\end{array}$

$\begin{array}{rr}190,0 & 5,830 \\ 00 & \end{array}$

0

- 480

- 618

- 700

- 766

- 976

1,01

$190,0 \quad 10,20$

$00 \quad 0$

$189,0 \quad 19,80$

$00 \quad 0$

$191,0 \quad 5,070$

189,0

$00 \quad 8,540$

- 219

191,0

$00 \quad 7,470$

- 216

$192,0 \quad 14,40$

$00 \quad 0$

$-427$

$191,0 \quad 20,20$

$00 \quad 0$

- 615

$192,0 \quad 22,70$

- 692

00
192,0

$\begin{array}{rr}192,0 & 6,300\end{array}$

- 204

$192,0 \quad 15,20$

- 438

$00 \quad 0$

$195,0 \quad 28,10$

$00 \quad 0$

- 790

$191,0 \quad 27,40$

$00 \quad 0$

- 791

192,0

$\begin{array}{rrrr}192,0 & 4,690 \quad-\quad & - & 88\end{array}$

$190,0 \quad 6,240$

$00 \quad 6,240$ 


\begin{tabular}{|c|c|c|c|c|c|c|c|c|c|c|}
\hline YG15 & 121 & 473 & $\begin{array}{r}11,0 \\
00\end{array}$ & $\begin{array}{r}100,0 \\
00\end{array}$ & $\begin{array}{r}10,60 \\
0\end{array}$ & 521 & $\begin{array}{r}191,0 \\
00\end{array}$ & $\begin{array}{r}12,00 \\
0\end{array}$ & - & - 301 \\
\hline YG100 & 120 & 806 & $\begin{array}{r}4,52 \\
0\end{array}$ & $\begin{array}{r}112,0 \\
00\end{array}$ & 5,160 & 228 & $\begin{array}{r}191,0 \\
00\end{array}$ & 6,020 & - & 164 \\
\hline YH1 & 126 & 100 & $\begin{array}{r}51,0 \\
00\end{array}$ & $\begin{array}{r}37,30 \\
0\end{array}$ & $\begin{array}{r}26,80 \\
0\end{array}$ & $\begin{array}{r}2,46 \\
0\end{array}$ & $\begin{array}{r}207,0 \\
00\end{array}$ & $\begin{array}{r}44,40 \\
0\end{array}$ & - & $\begin{array}{r}2,03 \\
-\quad 0\end{array}$ \\
\hline YH100 & 125 & 137 & $\begin{array}{r}53,2 \\
00\end{array}$ & $\begin{array}{r}34,00 \\
0\end{array}$ & $\begin{array}{r}19,90 \\
0\end{array}$ & $\begin{array}{r}2,59 \\
0\end{array}$ & $\begin{array}{r}212,0 \\
00\end{array}$ & $\begin{array}{r}29,20 \\
0\end{array}$ & - & $\begin{array}{r}1,95 \\
-\quad 0\end{array}$ \\
\hline YH250 & 125 & 87 & $\begin{array}{r}53,9 \\
00\end{array}$ & $\begin{array}{r}32,40 \\
0\end{array}$ & $\begin{array}{r}19,90 \\
0\end{array}$ & $\begin{array}{r}2,59 \\
0\end{array}$ & $\begin{array}{r}213,0 \\
00\end{array}$ & $\begin{array}{r}29,50 \\
0\end{array}$ & - & $\begin{array}{r}2,04 \\
-\quad 0\end{array}$ \\
\hline YI8 & 121 & 517 & $\begin{array}{r}8,41 \\
0\end{array}$ & $\begin{array}{r}105,0 \\
00\end{array}$ & 8,800 & 362 & $\begin{array}{r}192,0 \\
00\end{array}$ & 9,030 & - & 273 \\
\hline YI100 & 121 & 533 & $\begin{array}{r}9,33 \\
0\end{array}$ & $\begin{array}{r}101,0 \\
00\end{array}$ & 9,310 & 399 & $\begin{array}{r}192,0 \\
00\end{array}$ & 9,590 & - & 305 \\
\hline YI450 & 121 & 509 & $\begin{array}{r}9,84 \\
0\end{array}$ & $\begin{array}{r}100,0 \\
00\end{array}$ & 9,930 & 411 & $\begin{array}{r}191,0 \\
00\end{array}$ & $\begin{array}{r}10,10 \\
0\end{array}$ & - & 321 \\
\hline YI800 & 121 & 437 & $\begin{array}{r}11,0 \\
00\end{array}$ & $\begin{array}{r}95,40 \\
0\end{array}$ & $\begin{array}{r}11,00 \\
0\end{array}$ & 48 & $\begin{array}{r}1 ? 1,0 \\
00\end{array}$ & $\begin{array}{r}11,50 \\
0\end{array}$ & - & 351 \\
\hline YJ17 & 120 & 698 & $\begin{array}{r}6,66 \\
0\end{array}$ & $\begin{array}{r}110,0 \\
00\end{array}$ & 8,640 & $\therefore 1$ & $\begin{array}{r}193,0 \\
00\end{array}$ & 8,110 & - & 271 \\
\hline YJ100 & 121 & 461 & $\begin{array}{r}11,8 \\
00\end{array}$ & $\begin{array}{r}94,10 \\
0\end{array}$ & 12.70 & 545 & $\begin{array}{r}194,0 \\
00\end{array}$ & $\begin{array}{r}12,80 \\
0\end{array}$ & - & 428 \\
\hline YJ400 & 122 & 257 & $\begin{array}{r}16,9 \\
00\end{array}$ & $\begin{array}{r}88,80 \\
0\end{array}$ & $\begin{array}{r}16,10 \\
0\end{array}$ & 743 & $\begin{array}{r}189,0 \\
00\end{array}$ & $\begin{array}{r}27,20 \\
0\end{array}$ & - & 620 \\
\hline YK1 & 120 & 710 & $\begin{array}{r}7,78 \\
0\end{array}$ & $\begin{array}{r}1050 \\
\text { ᄂ? }\end{array}$ & $\hat{\imath}, 210$ & 325 & $\begin{array}{r}191,0 \\
00\end{array}$ & $\begin{array}{r}10,40 \\
0\end{array}$ & - & 277 \\
\hline YK100 & 121 & 529 & $\begin{array}{r}9,8^{-} \\
0\end{array}$ & $\begin{array}{r}1,1,0 \\
00\end{array}$ & $\begin{array}{r}10,20 \\
0\end{array}$ & 410 & $\begin{array}{r}192,0 \\
00\end{array}$ & $\begin{array}{r}11,70 \\
0\end{array}$ & - & 320 \\
\hline YK400 & 122 & 304 & $\begin{array}{r}151 \\
\text { nu }\end{array}$ & $\begin{array}{r}93,60 \\
0\end{array}$ & $\begin{array}{r}13,90 \\
0\end{array}$ & 584 & $\begin{array}{r}190,0 \\
00\end{array}$ & $\begin{array}{r}24,00 \\
0\end{array}$ & - & 522 \\
\hline YK700 & 122 & 281 & $\begin{array}{c}1 \mathrm{~s}, \mathrm{c} \\
\mathrm{vo}\end{array}$ & $\begin{array}{r}97,50 \\
0\end{array}$ & $\begin{array}{r}15,30 \\
0\end{array}$ & 634 & $\begin{array}{r}189,0 \\
00\end{array}$ & $\begin{array}{r}27,00 \\
0\end{array}$ & - & -576 \\
\hline YL22 & 120 & 94 & $\begin{array}{r}4,37 \\
0\end{array}$ & $\begin{array}{r}112,0 \\
00\end{array}$ & 4,930 & 156 & $\begin{array}{r}192,0 \\
00\end{array}$ & 6,250 & - & 141 \\
\hline YL100 & $12:$ & 4,5 & $\begin{array}{r}9,38 \\
0\end{array}$ & $\begin{array}{r}102,0 \\
00\end{array}$ & 9,580 & 375 & $\begin{array}{r}193,0 \\
00\end{array}$ & $\begin{array}{r}12,80 \\
0\end{array}$ & - & 324 \\
\hline YL400 & ? & 421 & $\begin{array}{r}10,4 \\
00\end{array}$ & $\begin{array}{r}100,0 \\
00\end{array}$ & $\begin{array}{r}10,50 \\
0\end{array}$ & 423 & $\begin{array}{r}191,0 \\
00\end{array}$ & $\begin{array}{r}14,80 \\
0\end{array}$ & - & 360 \\
\hline RA130 & 1)1 & 429 & 197 & 1,550 & 80 & 10 & 3,380 & 600 & - & 21 \\
\hline RB180 & 102 & $\begin{array}{r}1,20 \\
0\end{array}$ & 566 & 6,650 & 300 & 27 & $\begin{array}{r}12,50 \\
0\end{array}$ & 2,400 & - & 31 \\
\hline RC120 & 105 & 846 & $\begin{array}{r}3,40 \\
0\end{array}$ & $\begin{array}{r}19,60 \\
0\end{array}$ & 1,800 & 14 & $\begin{array}{r}40,10 \\
0\end{array}$ & 5,700 & - & 116 \\
\hline RD160 & 109 & $\begin{array}{r}1,95 \\
0\end{array}$ & $\begin{array}{r}4,67 \\
0\end{array}$ & $\begin{array}{r}39,80 \\
0\end{array}$ & 3,200 & 217 & $\begin{array}{r}79,50 \\
0\end{array}$ & 5,120 & - & 250 \\
\hline RE100 & 114 & $\begin{array}{r}2,67 \\
0\end{array}$ & $\begin{array}{r}8,65 \\
0\end{array}$ & $\begin{array}{r}61,60 \\
0\end{array}$ & 6,140 & 575 & $\begin{array}{r}129,0 \\
00\end{array}$ & 3,600 & - & 481 \\
\hline RF90 & 115 & $\begin{array}{r}1,66 \\
0\end{array}$ & $\begin{array}{r}9,43 \\
0\end{array}$ & $\begin{array}{r}65,10 \\
0\end{array}$ & 7,310 & 631 & $\begin{array}{r}135,0 \\
00\end{array}$ & 5,700 & - & 837 \\
\hline RG30 & 116 & $\begin{array}{r}1,25 \\
0\end{array}$ & $\begin{array}{r}11,4 \\
00\end{array}$ & $\begin{array}{r}69,20 \\
0\end{array}$ & 7,900 & 674 & $\begin{array}{r}147,0 \\
00\end{array}$ & 7,650 & - & 546 \\
\hline RH10 & 121 & 565 & $\begin{array}{r}10,2 \\
00\end{array}$ & $\begin{array}{r}97,50 \\
0\end{array}$ & $\begin{array}{r}10,50 \\
0\end{array}$ & 538 & $\begin{array}{r}190,0 \\
00\end{array}$ & $\begin{array}{r}11,10 \\
0\end{array}$ & - & 368 \\
\hline RI15 & 120 & 457 & $\begin{array}{r}13,5 \\
00\end{array}$ & $\begin{array}{r}81,90 \\
0\end{array}$ & $\begin{array}{r}12,40 \\
0\end{array}$ & 736 & $\begin{array}{r}171,0 \\
00\end{array}$ & $\begin{array}{r}15,60 \\
0\end{array}$ & - & 507 \\
\hline
\end{tabular}




\begin{tabular}{|c|c|c|c|c|c|c|c|c|c|c|c|}
\hline RJ10 & 122 & 390 & $\begin{array}{r}11,4 \\
00\end{array}$ & $\begin{array}{r}95,70 \\
0\end{array}$ & $\begin{array}{r}11,00 \\
0\end{array}$ & 633 & $\begin{array}{r}190,0 \\
00\end{array}$ & $\begin{array}{r}12,80 \\
0\end{array}$ & - & - & 626 \\
\hline RK90 & 115 & $\begin{array}{r}1,93 \\
0\end{array}$ & $\begin{array}{r}10,5 \\
00\end{array}$ & $\begin{array}{r}62,60 \\
0\end{array}$ & 7,820 & 701 & $\begin{array}{r}137,0 \\
00\end{array}$ & 5,100 & - & & $\begin{array}{r}1,02 \\
0\end{array}$ \\
\hline RL110 & 111 & $\begin{array}{r}2,53 \\
0\end{array}$ & $\begin{array}{r}6,44 \\
0\end{array}$ & $\begin{array}{r}45,50 \\
0\end{array}$ & 5,000 & 417 & $\begin{array}{r}96,60 \\
0\end{array}$ & 4,830 & - & - & 971 \\
\hline RM100 & 109 & $\begin{array}{r}2,13 \\
0\end{array}$ & $\begin{array}{r}5,78 \\
0\end{array}$ & $\begin{array}{r}37,00 \\
0\end{array}$ & 4,500 & 347 & $\begin{array}{r}80,20 \\
0\end{array}$ & 5,100 & - & - & 318 \\
\hline RN75 & 115 & $\begin{array}{r}2,02 \\
0\end{array}$ & $\begin{array}{r}3,89 \\
0\end{array}$ & $\begin{array}{r}79,10 \\
0\end{array}$ & 4,500 & 359 & $\begin{array}{r}132,0 \\
00\end{array}$ & 5,000 & - & - & 491 \\
\hline RO80 & 114 & $\begin{array}{r}1,59 \\
0\end{array}$ & $\begin{array}{r}6,73 \\
0\end{array}$ & $\begin{array}{r}62,60 \\
0\end{array}$ & 5,400 & 483 & $\begin{array}{r}122,0 \\
00\end{array}$ & 7,200 & - & - & 965 \\
\hline RP50 & 110 & $\begin{array}{r}1,96 \\
0\end{array}$ & $\begin{array}{r}2,33 \\
0\end{array}$ & $\begin{array}{r}45,50 \\
0\end{array}$ & 2,800 & 182 & $\begin{array}{r}82,00 \\
0\end{array}$ & 6,990 & - & - & 137 \\
\hline RQ70 & 113 & $\begin{array}{r}1,32 \\
0\end{array}$ & $\begin{array}{r}5,27 \\
0\end{array}$ & $\begin{array}{r}62,60 \\
0\end{array}$ & 4,500 & 272 & $\begin{array}{r}110,0 \\
00\end{array}$ & 9,700 & - & - & 507 \\
\hline RR60 & 116 & $\begin{array}{r}1,24 \\
0\end{array}$ & $\begin{array}{r}4,13 \\
0\end{array}$ & $\begin{array}{r}88,10 \\
0\end{array}$ & 4,500 & $23 !$ & $\begin{array}{r}15,0 \\
00\end{array}$ & 7,250 & - & - & 419 \\
\hline RS15 & 127 & 52 & $\begin{array}{r}69,0 \\
00\end{array}$ & $\begin{array}{r}12,50 \\
0\end{array}$ & $\begin{array}{r}17,60 \\
0\end{array}$ & $\frac{1,23}{v}$ & $\begin{array}{r}231,0 \\
00\end{array}$ & $\begin{array}{r}31,40 \\
0\end{array}$ & - & & $\begin{array}{r}3,70 \\
0\end{array}$ \\
\hline RT15 & 127 & 60 & $\begin{array}{r}68,8 \\
00\end{array}$ & $\begin{array}{r}14,00 \\
0\end{array}$ & $17, F^{\circ}$ & $\begin{array}{r}4,93 \\
0\end{array}$ & $\begin{array}{r}229,0 \\
00\end{array}$ & $\begin{array}{r}29,50 \\
0\end{array}$ & - & & $\begin{array}{r}3,52 \\
0\end{array}$ \\
\hline RU1 & 124 & 238 & $\begin{array}{r}27,2 \\
00\end{array}$ & $\begin{array}{r}66,20 \\
0\end{array}$ & $\begin{array}{r}26,40 \\
0\end{array}$ & $\begin{array}{r}1,60 \\
0\end{array}$ & $\begin{array}{r}198,0 \\
00\end{array}$ & $\begin{array}{r}30,90 \\
0\end{array}$ & - & - & $\begin{array}{r}1,42 \\
0\end{array}$ \\
\hline RV20 & 122 & 413 & $\begin{array}{r}13,4 \\
00\end{array}$ & $\begin{array}{r}1010 \\
\text { ᄂ }\end{array}$ & $\begin{array}{r}11,70 \\
0\end{array}$ & 563 & $\begin{array}{r}189,0 \\
00\end{array}$ & $\begin{array}{r}13,90 \\
0\end{array}$ & - & - & 507 \\
\hline RW10 & 122 & 338 & $\begin{array}{r}15, \\
00\end{array}$ & $\begin{array}{r}9^{\prime}, 50 \\
0\end{array}$ & $\begin{array}{r}15,70 \\
0\end{array}$ & 763 & $\begin{array}{r}191,0 \\
00\end{array}$ & $\begin{array}{r}19,80 \\
0\end{array}$ & - & - & 623 \\
\hline RX10 & 127 & 69 & $\begin{array}{r}\mathrm{C}^{1} 0 \\
\mathrm{nu}\end{array}$ & $\begin{array}{r}21,30 \\
0\end{array}$ & $\begin{array}{r}19,10 \\
0\end{array}$ & $\begin{array}{r}3,55 \\
0\end{array}$ & $\begin{array}{r}223,0 \\
00\end{array}$ & $\begin{array}{r}32,00 \\
0\end{array}$ & - & - & $\begin{array}{r}3,45 \\
0\end{array}$ \\
\hline RY95 & 116 & $\begin{array}{r}1,84 \\
\text { 's }\end{array}$ & $1 /$, & $\begin{array}{r}63,00 \\
0\end{array}$ & 6,840 & 763 & $\begin{array}{r}138,0 \\
00\end{array}$ & 6,100 & - & - & 766 \\
\hline RZ1 & 128 & & $\begin{array}{r}75,3 \\
00\end{array}$ & $\begin{array}{r}10,70 \\
0\end{array}$ & $\begin{array}{r}15,10 \\
0\end{array}$ & $\begin{array}{r}4,72 \\
0\end{array}$ & $\begin{array}{r}253,0 \\
00\end{array}$ & $\begin{array}{r}26,50 \\
0\end{array}$ & - & - & $\begin{array}{r}4,33 \\
0\end{array}$ \\
\hline CA0 & $12-$ & & $\begin{array}{r}10,9 \\
00 \\
\end{array}$ & $\begin{array}{r}105,0 \\
00 \\
\end{array}$ & 9,230 & 237 & $\begin{array}{r}185,0 \\
00 \\
\end{array}$ & $\begin{array}{r}28,10 \\
0 \\
\end{array}$ & - & - & 720 \\
\hline \multicolumn{12}{|c|}{ COIPASA } \\
\hline sample & $\mathrm{T}_{1} \mathrm{~S}$ & $\mathrm{Ca}$ & $\mathrm{Mg}$ & $\mathrm{Na}$ & $\mathrm{K}$ & $\mathrm{Li}$ & $\mathrm{Cl}$ & $\mathrm{SO} 4$ & $\begin{array}{r}\mathrm{CO} \\
3 \\
\end{array}$ & $\begin{array}{r}\mathrm{HC} \\
\mathrm{O} 3\end{array}$ & B \\
\hline $\mathrm{C} 0$ & 368 & 253 & $\begin{array}{r}12,1 \\
20\end{array}$ & $\begin{array}{r}100,4 \\
00\end{array}$ & 9,080 & 338 & $\begin{array}{r}186,0 \\
00\end{array}$ & $\begin{array}{r}25,30 \\
0\end{array}$ & - & 785 & $\begin{array}{r}2,20 \\
8\end{array}$ \\
\hline CA150 & 124 & 194 & $\begin{array}{r}14,1 \\
00\end{array}$ & $\begin{array}{r}104,0 \\
00\end{array}$ & $\begin{array}{r}10,00 \\
0\end{array}$ & 275 & $\begin{array}{r}172,0 \\
00\end{array}$ & $\begin{array}{r}54,00 \\
0\end{array}$ & - & - & 870 \\
\hline CA250 & 126 & 164 & $\begin{array}{r}10,5 \\
00\end{array}$ & $\begin{array}{r}111,0 \\
00\end{array}$ & 8,330 & 212 & $\begin{array}{r}132,0 \\
00\end{array}$ & $\begin{array}{r}104,0 \\
00\end{array}$ & - & - & 644 \\
\hline CB0 & 123 & 301 & $\begin{array}{r}10,7 \\
00\end{array}$ & $\begin{array}{r}108,0 \\
00\end{array}$ & 9,190 & 237 & $\begin{array}{r}187,0 \\
00\end{array}$ & $\begin{array}{r}29,30 \\
0\end{array}$ & - & - & 690 \\
\hline CB150 & 126 & 102 & $\begin{array}{r}23,0 \\
00\end{array}$ & $\begin{array}{r}94,70 \\
0\end{array}$ & $\begin{array}{r}14,30 \\
0\end{array}$ & 416 & $\begin{array}{r}168,0 \\
00\end{array}$ & $\begin{array}{r}80,10 \\
0\end{array}$ & - & - & $\begin{array}{r}1,35 \\
0\end{array}$ \\
\hline C10 & 121 & 541 & $\begin{array}{r}10,2 \\
00\end{array}$ & $\begin{array}{r}104,0 \\
00\end{array}$ & 7,120 & 198 & $\begin{array}{r}189,0 \\
00\end{array}$ & $\begin{array}{r}14,70 \\
0\end{array}$ & - & - & 601 \\
\hline $\mathrm{C} 20$ & 122 & 521 & $\begin{array}{r}15,1 \\
00\end{array}$ & $\begin{array}{r}99,10 \\
0\end{array}$ & $\begin{array}{r}11,60 \\
0\end{array}$ & 333 & $\begin{array}{r}188,0 \\
00\end{array}$ & $\begin{array}{r}17,60 \\
0\end{array}$ & - & - & 952 \\
\hline C3 & 122 & 319 & 10,1 & 109,0 & 7,310 & 205 & 179,0 & 25,90 & - & - & 614 \\
\hline
\end{tabular}




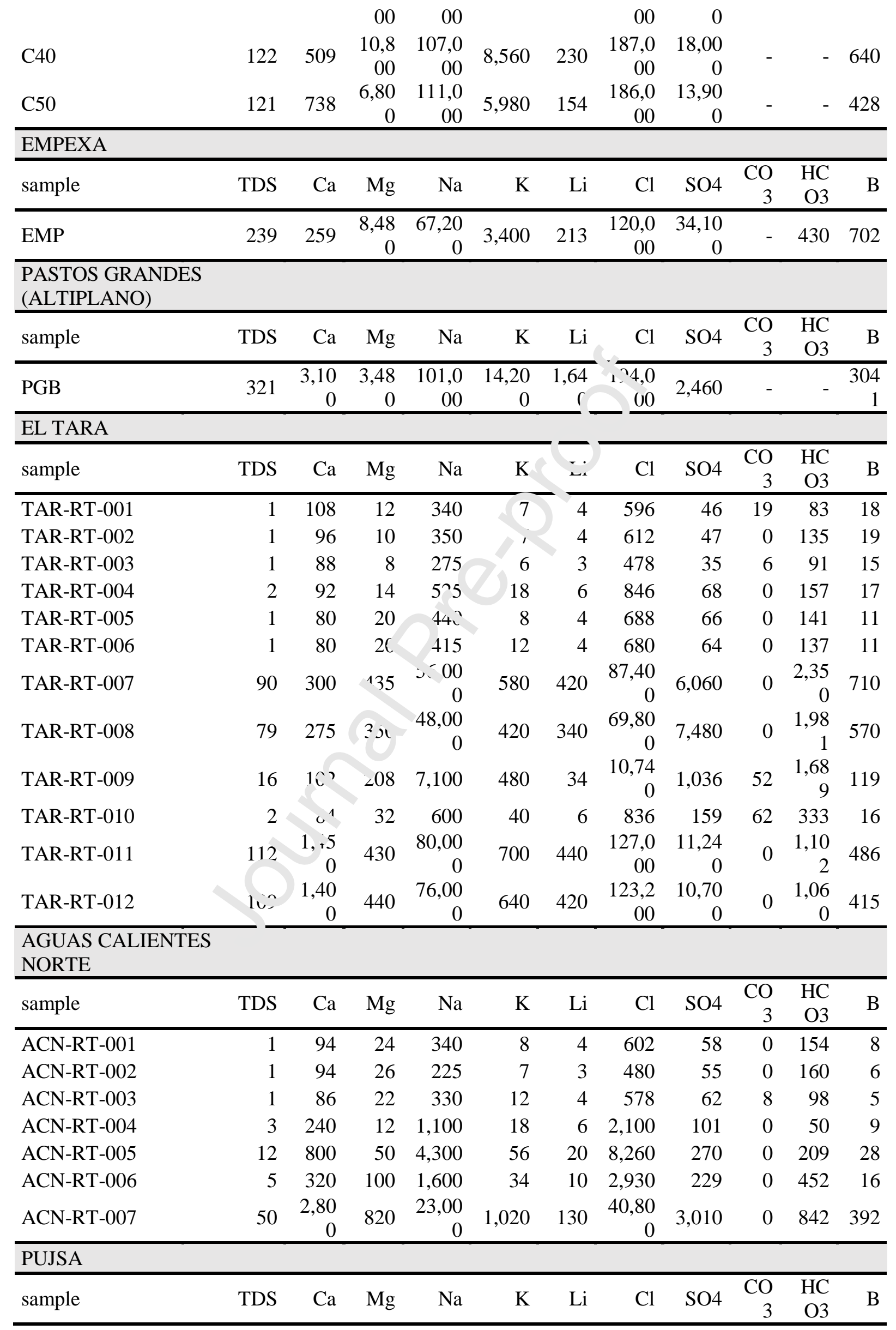




\begin{tabular}{|c|c|c|c|c|c|c|c|c|c|c|c|}
\hline PUJ-RT-001 & - & 125 & 35 & 280 & 28 & 2 & 338 & 384 & 0 & 173 & 0 \\
\hline PUJ-RT-002 & - & 180 & 790 & $\begin{array}{r}26,00 \\
0\end{array}$ & 2,825 & 175 & $\begin{array}{r}37,00 \\
0\end{array}$ & $\begin{array}{r}15,00 \\
0\end{array}$ & 834 & $\begin{array}{r}1,32 \\
4\end{array}$ & 450 \\
\hline PUJ-RT-003 & - & 180 & 835 & $\begin{array}{r}32,00 \\
0\end{array}$ & 3,175 & 200 & $\begin{array}{r}39,80 \\
0\end{array}$ & $\begin{array}{r}22,60 \\
0\end{array}$ & $\begin{array}{r}1,01 \\
6\end{array}$ & $\begin{array}{r}1,47 \\
7\end{array}$ & 529 \\
\hline PUJ-RT-004 & - & 70 & 28 & 260 & 26 & 1 & 286 & 264 & 0 & 225 & 0 \\
\hline PUJ-RT-005 & - & 50 & 12 & 220 & 16 & 1 & 232 & 208 & 0 & 128 & 0 \\
\hline PUJ-RT-006 & - & 175 & 250 & $\begin{array}{r}23,00 \\
0\end{array}$ & 975 & 60 & $\begin{array}{r}12,88 \\
0\end{array}$ & $\begin{array}{r}32,20 \\
0\end{array}$ & 586 & 0 & 177 \\
\hline PUJ-RT-007 & - & 300 & 98 & 9,500 & 300 & 20 & 3,520 & $\begin{array}{r}15,44 \\
0\end{array}$ & 457 & 0 & 184 \\
\hline PUJ-RT-008 & - & 80 & 16 & 1,050 & 32 & 2 & 441 & 1,600 & 52 & 186 & 0 \\
\hline PUJ-RT-009 & - & $\begin{array}{r}1,00 \\
0\end{array}$ & $\begin{array}{r}1,51 \\
5\end{array}$ & $\begin{array}{r}52,00 \\
0\end{array}$ & 3,400 & 400 & $\begin{array}{r}87,20 \\
0\end{array}$ & $\begin{array}{r}14,34 \\
0\end{array}$ & 0 & $\begin{array}{r}1,54 \\
2\end{array}$ & 317 \\
\hline PUJ-RT-010 & - & 525 & 183 & $\begin{array}{r}13,00 \\
0 \\
\end{array}$ & 525 & 27 & $5, \iota^{\Upsilon 70}$ & $\begin{array}{r}21,96 \\
0 \\
\end{array}$ & 548 & 568 & 230 \\
\hline \multicolumn{12}{|l|}{ LOYOQUES } \\
\hline sample & TDS & $\mathrm{Ca}$ & $\mathrm{Mg}$ & $\mathrm{Na}$ & $\mathrm{K}$ & $\mathrm{Ii}$ & $\mathrm{Cl}$ & $\mathrm{SO} 4$ & $\begin{array}{r}\mathrm{CO} \\
3 \\
\end{array}$ & $\begin{array}{r}\mathrm{HC} \\
\mathrm{O} 3 \\
\end{array}$ & B \\
\hline LOY-RT-001 & 3 & 220 & 34 & 890 & & 6 & 1,765 & 97 & 40 & 0 & 4 \\
\hline LOY-RT-002 & 123 & $\begin{array}{r}18,0 \\
00\end{array}$ & $\begin{array}{r}2,30 \\
0\end{array}$ & 9,600 & $12 \mathrm{~J}$ & 350 & $\begin{array}{r}202,0 \\
00\end{array}$ & 1,820 & 0 & 655 & 430 \\
\hline LOY-RT-003 & 123 & $\begin{array}{r}15,8 \\
50\end{array}$ & $\begin{array}{r}2,47 \\
5\end{array}$ & $\begin{array}{r}100, C \\
1,0\end{array}$ & 23 & 375 & $\begin{array}{r}196,8 \\
00\end{array}$ & 1,720 & 0 & 779 & 681 \\
\hline LOY-RT-004 & 122 & $\begin{array}{r}17,6 \\
00\end{array}$ & 2,85 & $\begin{array}{r}>, 0 \\
0\end{array}$ & 128 & 425 & $\begin{array}{r}194,8 \\
00\end{array}$ & 1,840 & 0 & 827 & 756 \\
\hline LOY-RT-005 & 102 & 5600 & $\begin{array}{r}2,13 \\
5\end{array}$ & $\begin{array}{r}0^{2} 00 \\
0 \\
\end{array}$ & 1,650 & 275 & $\begin{array}{r}114,2 \\
00 \\
\end{array}$ & 2,600 & 0 & 733 & 527 \\
\hline \multicolumn{12}{|c|}{$\begin{array}{l}\text { AGUAS CALIENTES } \\
\text { CENTRO }\end{array}$} \\
\hline sample & TDS & & $\mathrm{Mg}$ & $\mathrm{Na}$ & $\mathrm{K}$ & $\mathrm{Li}$ & $\mathrm{Cl}$ & $\mathrm{SO} 4$ & $\begin{array}{r}\mathrm{CO} \\
3 \\
\end{array}$ & $\begin{array}{r}\mathrm{HC} \\
\mathrm{O} 3 \\
\end{array}$ & B \\
\hline ACC-RT-001 & 15 & $\frac{42}{5}$ & 415 & 3,750 & 325 & 10 & $\begin{array}{r}10,74 \\
0\end{array}$ & 1,302 & 0 & 143 & 0 \\
\hline ACC-RT-002 & & 600 & 413 & 2,150 & 228 & 5 & 4,660 & 752 & 0 & 448 & 0 \\
\hline ACC-RT-003 & & $\begin{array}{r}1,65 \\
0\end{array}$ & 273 & 2,600 & 240 & 8 & 7,260 & 882 & 0 & 142 & 0 \\
\hline ACC-RT-004 & 44 & 875 & $\begin{array}{r}3,33 \\
8\end{array}$ & $\begin{array}{r}19,00 \\
0\end{array}$ & 1,025 & 45 & $\begin{array}{r}33,80 \\
0\end{array}$ & 5,530 & 0 & 819 & 33 \\
\hline ACC-RT-005 & 9 & 575 & 293 & 2,800 & 150 & 8 & 5,840 & 236 & 0 & 144 & 0 \\
\hline \multicolumn{12}{|l|}{ EL LACO } \\
\hline sample & TDS & $\mathrm{Ca}$ & $\mathrm{Mg}$ & $\mathrm{Na}$ & $\mathrm{K}$ & $\mathrm{Li}$ & $\mathrm{Cl}$ & $\mathrm{SO} 4$ & $\begin{array}{r}\mathrm{CO} \\
3 \\
\end{array}$ & $\begin{array}{r}\mathrm{HC} \\
\mathrm{O} 3 \\
\end{array}$ & B \\
\hline LAC0 & 210 & 820 & $\begin{array}{r}6,25 \\
1\end{array}$ & $\begin{array}{r}62,20 \\
0\end{array}$ & 4,800 & 101 & $\begin{array}{r}109,6 \\
30\end{array}$ & $\begin{array}{r}15,36 \\
0\end{array}$ & - & 620 & $\begin{array}{r}1,07 \\
8\end{array}$ \\
\hline LAC-RT-001 & 44 & $\begin{array}{r}1,30 \\
0\end{array}$ & $\begin{array}{r}2,03 \\
5\end{array}$ & $\begin{array}{r}19,00 \\
0\end{array}$ & 1,525 & 40 & $\begin{array}{r}34,20 \\
0\end{array}$ & 5,370 & 0 & 400 & 0 \\
\hline LAC-RT-002 & 47 & $\begin{array}{r}1,22 \\
5\end{array}$ & $\begin{array}{r}2,64 \\
5\end{array}$ & $\begin{array}{r}21,00 \\
0\end{array}$ & 1,850 & 33 & $\begin{array}{r}36,30 \\
0\end{array}$ & 7,280 & 0 & 428 & 0 \\
\hline LAC-RT-003 & 43 & 800 & $\begin{array}{r}2,16 \\
5\end{array}$ & $\begin{array}{r}19,00 \\
0\end{array}$ & 1,550 & 28 & $\begin{array}{r}32,20 \\
0\end{array}$ & 5,930 & 0 & 370 & 0 \\
\hline LAC-RT-004 & 26 & 775 & 1,10 & 12,00 & 900 & 20 & 18,08 & 3,768 & 0 & 367 & 0 \\
\hline
\end{tabular}


$\begin{array}{lll}2 & 0 & 0\end{array}$

\begin{tabular}{lrrrrrrrrrrr} 
LAC-RT-005 & 2 & 190 & 34 & 650 & 95 & 2 & 1,090 & 340 & 0 & 175 & 0 \\
\hline AGUAS CALIENTES SUR & & & & & & & & & \\
\hline sample & TDS & $\mathrm{Ca}$ & $\mathrm{Mg}$ & $\mathrm{Na}$ & $\mathrm{K}$ & $\mathrm{Li}$ & $\mathrm{Cl}$ & $\mathrm{SO} 4$ & $\mathrm{CO}$ & $\mathrm{HC}$ & $\mathrm{B}$ \\
\hline ACT-RT-001 & 33 & 1,62 & 1,37 & 13,00 & 900 & 18 & 24,36 & 4,160 & 0 & 225 & 0 \\
ACT-RT-002 & 6 & 275 & 170 & 2,100 & 182 & 3 & 3,590 & 642 & 0 & 81 & 0 \\
ACT-RT-003 & 2 & 180 & 62 & 500 & 60 & 1 & 980 & 447 & 0 & 109 & 0 \\
ACT-RT-004 & 2 & 170 & 60 & 550 & 60 & 1 & 935 & 424 & 0 & 104 & 0 \\
ACT-RT-005 & 7 & 425 & 193 & 2,400 & 155 & 3 & 4,170 & 606 & 0 & 353 & 0 \\
ACT-RT-006 & 1 & 410 & 33 & 250 & 27 & 1 & 256 & 1,186 & 0 & 57 & 0 \\
ACT-RT-007 & 4 & 230 & 150 & 1,100 & 85 & 5 & 1,850 & 689 & 0 & 243 & 0 \\
ACT-RT-008 & 2 & 140 & 85 & 650 & 46 & 3 & 135 & 343 & 0 & 164 & 0 \\
\hline
\end{tabular}

AGUAS CALIENTES SUR

SUR

\begin{tabular}{|c|c|c|c|c|c|c|c|c|c|c|c|}
\hline sample & TDS & $\mathrm{Ca}$ & $\mathrm{Mg}$ & $\mathrm{Na}$ & $\mathrm{K}$ & $\mathrm{Li}$ & $\mathrm{Cl}$ & $\mathrm{SO} 4$ & $\begin{array}{r}\mathrm{CO} \\
3 \\
\end{array}$ & $\begin{array}{r}\mathrm{HC} \\
\mathrm{O} 3 \\
\end{array}$ & B \\
\hline ACS-RT-001 & 1 & 85 & 43 & 400 & rv & 1 & 590 & 332 & 0 & 92 & 1 \\
\hline ACS-RT-002 & 1 & 85 & 43 & 375 & & 1 & 594 & 334 & 0 & 93 & 1 \\
\hline ACS-RT-003 & 1 & 85 & 43 & 400 & 40 & 2 & 590 & 330 & 0 & 96 & 2 \\
\hline ACS-RT-004 & 25 & 750 & 850 & $\begin{array}{r}10,30 \\
0\end{array}$ & 150 & 35 & $\begin{array}{r}18,40 \\
0\end{array}$ & 4,060 & 66 & 349 & 131 \\
\hline ACS-RT-005 & 1 & 100 & 16 & 175 & 4 & $<1$ & 194 & 334 & 0 & 42 & 0 \\
\hline ACS-RT-006 & 1 & 100 & 16 & 175 & 3 & $<1$ & 193 & 344 & 0 & 42 & 0 \\
\hline ACS-RT-007 & 1 & 83 & 16 & 175 & 3 & $<1$ & 197 & 342 & 0 & 41 & 0 \\
\hline ACS-RT-008 & 3 & 190 & 100 & 875 & 100 & 3 & 1,380 & 1,010 & 0 & 111 & 9 \\
\hline ACS-RT-009 & 3 & 170 & $8 t$ & 750 & 80 & 2 & 1,115 & 895 & 0 & 99 & 7 \\
\hline ACS-RT-010 & 7 & 37) & y8 & 3,050 & 270 & 9 & 3,930 & 2,160 & 0 & 117 & 40 \\
\hline \multicolumn{12}{|l|}{ PAJONALES } \\
\hline sample & TDS & Ta & $\mathrm{Mg}$ & $\mathrm{Na}$ & $\mathrm{K}$ & $\mathrm{Li}$ & $\mathrm{Cl}$ & $\mathrm{SO} 4$ & $\begin{array}{r}\mathrm{CO} \\
3 \\
\end{array}$ & $\begin{array}{c}\mathrm{HC} \\
\mathrm{O} 3\end{array}$ & B \\
\hline PAJ-RT-001 & 16 & 775 & 500 & 6,500 & 325 & 6 & $\begin{array}{r}11,58 \\
0\end{array}$ & 1,084 & 0 & 76 & 36 \\
\hline PAJ-RT-002 & .5 & 775 & 475 & 5,800 & 305 & 6 & $\begin{array}{r}10,74 \\
0\end{array}$ & 894 & 0 & 74 & 31 \\
\hline PAJ-RT-003 & 1 & 625 & 250 & 5,000 & 285 & 5 & 8,940 & 1,042 & 0 & 75 & 27 \\
\hline PAJ-RT-004 & 36 & $\begin{array}{r}2,12 \\
5\end{array}$ & $\begin{array}{r}1,17 \\
5\end{array}$ & 1,360 & 925 & 16 & $\begin{array}{r}28,45 \\
0\end{array}$ & 2,850 & 0 & 190 & 85 \\
\hline PAJ-RT-005 & 35 & $\begin{array}{r}1,90 \\
0\end{array}$ & $\begin{array}{r}1,15 \\
0\end{array}$ & $\begin{array}{r}15,00 \\
0\end{array}$ & 900 & 16 & $\begin{array}{r}27,50 \\
0\end{array}$ & 2,685 & 0 & 182 & 91 \\
\hline PAJ-RT-006 & 39 & $\begin{array}{r}2,37 \\
5\end{array}$ & $\begin{array}{r}1,27 \\
5\end{array}$ & $\begin{array}{r}13,80 \\
0\end{array}$ & 1,025 & 18 & $\begin{array}{r}29,30 \\
0\end{array}$ & 3,100 & 0 & 208 & 102 \\
\hline PAJ-RT-007 & 67 & $\begin{array}{r}2,52 \\
5\end{array}$ & $\begin{array}{r}1,97 \\
5\end{array}$ & $\begin{array}{r}33,40 \\
0\end{array}$ & 1,725 & 58 & $\begin{array}{r}62,00 \\
0\end{array}$ & 2,550 & 0 & 314 & 177 \\
\hline PAJ-RT-008 & 71 & $\begin{array}{r}2,62 \\
5\end{array}$ & $\begin{array}{r}2,17 \\
5\end{array}$ & $\begin{array}{r}33,80 \\
0\end{array}$ & 1,825 & 62 & $\begin{array}{r}67,40 \\
0\end{array}$ & 2,820 & 0 & 448 & 190 \\
\hline PAJ-RT-009 & 48 & $\begin{array}{r}1,30 \\
0\end{array}$ & $\begin{array}{r}1,52 \\
5\end{array}$ & 2,050 & 1,275 & 40 & $\begin{array}{r}40,40 \\
0\end{array}$ & 1,650 & 0 & 334 & 125 \\
\hline PAJ-RT-010 & 78 & $\begin{array}{r}5,70 \\
0\end{array}$ & $\begin{array}{r}2,30 \\
0\end{array}$ & $\begin{array}{r}33,80 \\
0\end{array}$ & 1,675 & 31 & $\begin{array}{r}76,80 \\
0\end{array}$ & 590 & 0 & 193 & 86 \\
\hline
\end{tabular}




\begin{tabular}{|c|c|c|c|c|c|c|c|c|c|c|c|}
\hline PAJ-RT-011 & 54 & $\begin{array}{r}4,94 \\
5\end{array}$ & $\begin{array}{r}2,27 \\
5\end{array}$ & $\begin{array}{r}20,10 \\
0\end{array}$ & 1,208 & 18 & $\begin{array}{r}47,60 \\
0\end{array}$ & 780 & 0 & 134 & 54 \\
\hline PAJ-RT-012 & 47 & $\begin{array}{r}4,63 \\
5\end{array}$ & $\begin{array}{r}2,02 \\
5\end{array}$ & $\begin{array}{r}16,60 \\
0\end{array}$ & 1,135 & 18 & $\begin{array}{r}39,30 \\
0\end{array}$ & 0 & 0 & 135 & 46 \\
\hline PAJ-RT-013 & 68 & $\begin{array}{r}5,01 \\
8\end{array}$ & $\begin{array}{r}1,75 \\
0\end{array}$ & $\begin{array}{r}30,80 \\
0\end{array}$ & 1,803 & 35 & $\begin{array}{r}61,30 \\
0\end{array}$ & 3,700 & 0 & 511 & 329 \\
\hline PAJ-RT-014 & 69 & $\begin{array}{r}5,01 \\
8\end{array}$ & $\begin{array}{r}1,80 \\
0\end{array}$ & $\begin{array}{r}32,00 \\
0\end{array}$ & 1,828 & 35 & $\begin{array}{r}62,20 \\
0\end{array}$ & 3,730 & 0 & 523 & 349 \\
\hline PAJ-RT-015 & 69 & $\begin{array}{r}5,01 \\
8\end{array}$ & $\begin{array}{r}1,77 \\
5\end{array}$ & $\begin{array}{r}31,70 \\
0\end{array}$ & 1,810 & 35 & $\begin{array}{r}63,40 \\
0\end{array}$ & 3,720 & 0 & 516 & 334 \\
\hline PAJ-RT-016 & 96 & $\begin{array}{r}5,01 \\
8\end{array}$ & $\begin{array}{r}3,05 \\
0\end{array}$ & $\begin{array}{r}52,80 \\
0\end{array}$ & 2,800 & 45 & $\begin{array}{r}104,0 \\
00\end{array}$ & 200 & 0 & 864 & 524 \\
\hline PAJ-RT-017 & 96 & $\begin{array}{r}5,01 \\
5\end{array}$ & $\begin{array}{r}3,27 \\
5\end{array}$ & $\begin{array}{r}53,40 \\
0\end{array}$ & 2,825 & 44 & $\begin{array}{r}102,4 \\
00\end{array}$ & 2,820 & 0 & 854 & 457 \\
\hline PAJ-RT-018 & 84 & $\begin{array}{r}5,01 \\
8\end{array}$ & $\begin{array}{r}2,40 \\
0\end{array}$ & 4,120 & 2,315 & 41 & $\begin{array}{r}82,40 \\
0\end{array}$ & 3,380 & 0 & 704 & 402 \\
\hline PAJ-RT-019 & 19 & $\begin{array}{r}1,54 \\
0\end{array}$ & 375 & 6,100 & 353 & & $\begin{array}{r}1,90 \\
0\end{array}$ & 725 & 0 & 46 & 54 \\
\hline PAJ-RT-020 & 19 & $\begin{array}{r}1,54 \\
2\end{array}$ & 375 & 6,300 & 345 & 8 & $\begin{array}{r}13,35 \\
0\end{array}$ & 705 & 0 & 46 & 54 \\
\hline PAJ-RT-021 & 23 & $\begin{array}{r}2,06 \\
5\end{array}$ & 475 & 7,500 & $4 J 5$ & 9 & $\begin{array}{r}17,10 \\
0\end{array}$ & 865 & 0 & 52 & 58 \\
\hline PAJ-RT-022 & 23 & $\begin{array}{r}1,91 \\
5\end{array}$ & 450 & 7,600 & +10 & 9 & $\begin{array}{r}16,40 \\
0\end{array}$ & 1,055 & 0 & 60 & 59 \\
\hline PAJ-RT-023 & 24 & $\begin{array}{r}1,98 \\
0\end{array}$ & 500 & $7,8 \cdot 10$ & 430 & 10 & $\begin{array}{r}17,45 \\
0\end{array}$ & 1,155 & 0 & 64 & 64 \\
\hline PAJ-RT-024 & 23 & $\begin{array}{r}1,90 \\
0\end{array}$ & 475 &,- 800 & 405 & 10 & $\begin{array}{r}17,00 \\
0\end{array}$ & 1,085 & 0 & 63 & 62 \\
\hline PAJ-RT-025 & 103 & $\begin{array}{r}9,50 \\
0 \\
\end{array}$ & $52 \iota^{\prime}$ & $\begin{array}{r}50,80 \\
0 \\
\end{array}$ & 2,200 & 36 & $\begin{array}{r}118,8 \\
00 \\
\end{array}$ & 2,060 & 0 & 399 & 195 \\
\hline \multicolumn{12}{|l|}{ GORBEA } \\
\hline sample & TDS & & & $\mathrm{Na}$ & $\mathrm{K}$ & $\mathrm{Li}$ & $\mathrm{Cl}$ & $\mathrm{SO} 4$ & $\begin{array}{r}\mathrm{CO} \\
3 \\
\end{array}$ & $\begin{array}{r}\mathrm{HC} \\
\mathrm{O} 3 \\
\end{array}$ & B \\
\hline GOR-RT-001 & 66 & 193 & $\begin{array}{r}39,5 \\
00\end{array}$ & $\begin{array}{r}66,00 \\
0\end{array}$ & 5,000 & 475 & $\begin{array}{r}162,8 \\
06\end{array}$ & $\begin{array}{r}107,3 \\
67\end{array}$ & 0 & 0 & $\begin{array}{r}2,08 \\
4\end{array}$ \\
\hline GOR-RT-002 & & 165 & $\begin{array}{r}38,5 \\
00\end{array}$ & $\begin{array}{r}64,00 \\
0\end{array}$ & 4,600 & 500 & $\begin{array}{r}156,5 \\
95\end{array}$ & $\begin{array}{r}102,3 \\
55\end{array}$ & 0 & 0 & $\begin{array}{r}1,98 \\
6\end{array}$ \\
\hline GOR-RT-003 & & 410 & $\begin{array}{r}27,5 \\
00\end{array}$ & $\begin{array}{r}52,00 \\
0\end{array}$ & 5,000 & 300 & $\begin{array}{r}124,7 \\
11\end{array}$ & $\begin{array}{r}74,82 \\
5\end{array}$ & 0 & 0 & $\begin{array}{r}1,50 \\
9\end{array}$ \\
\hline GOR-RT-004 & 76 & 275 & $\begin{array}{r}28,0 \\
00\end{array}$ & $\begin{array}{r}52,00 \\
0\end{array}$ & 5,000 & 300 & $\begin{array}{r}123,7 \\
53\end{array}$ & $\begin{array}{r}74,29 \\
0\end{array}$ & 0 & 0 & $\begin{array}{r}1,45 \\
8\end{array}$ \\
\hline GOR-RT-005 & 5 & 425 & 550 & 1,300 & 25 & 5 & 2,486 & 3,107 & 0 & 0 & $\begin{array}{r}4,55 \\
9\end{array}$ \\
\hline \multicolumn{12}{|c|}{ AGUA AMARGA } \\
\hline sample & TDS & $\mathrm{Ca}$ & $\mathrm{Mg}$ & $\mathrm{Na}$ & $\mathrm{K}$ & $\mathrm{Li}$ & $\mathrm{Cl}$ & $\mathrm{SO} 4$ & $\begin{array}{r}\mathrm{CO} \\
3 \\
\end{array}$ & $\begin{array}{r}\mathrm{HC} \\
\mathrm{O} 3 \\
\end{array}$ & B \\
\hline AAM-RT-001 & 15 & 2363 & 325 & 3,600 & 185 & 14 & $\begin{array}{r}10,54 \\
0\end{array}$ & 1,308 & 0 & 112 & 69 \\
\hline AAM-RT-002 & 15 & 2448 & 300 & 3,700 & 198 & 14 & $\begin{array}{r}10,65 \\
0\end{array}$ & 1,150 & 0 & 113 & 69 \\
\hline AAM-RT-003 & 109 & $\begin{array}{r}23,0 \\
00\end{array}$ & $\begin{array}{r}3,52 \\
5\end{array}$ & $\begin{array}{r}51,20 \\
0\end{array}$ & 1,980 & 58 & $\begin{array}{r}136,0 \\
00\end{array}$ & 1,120 & 0 & 166 & 397 \\
\hline AAM-RT-004 & 113 & $\begin{array}{r}25,0 \\
00\end{array}$ & $\begin{array}{r}4,22 \\
5\end{array}$ & $\begin{array}{r}59,40 \\
0\end{array}$ & 2,035 & 61 & $\begin{array}{r}150,0 \\
00\end{array}$ & 1,200 & 0 & 162 & 426 \\
\hline
\end{tabular}




\begin{tabular}{|c|c|c|c|c|c|c|c|c|c|c|c|}
\hline AAM-RT-005 & 105 & $\begin{array}{r}23,0 \\
00\end{array}$ & $\begin{array}{r}3,00 \\
0\end{array}$ & $\begin{array}{r}47,60 \\
0\end{array}$ & 1,683 & 56 & $\begin{array}{r}124,4 \\
00\end{array}$ & 1,120 & 0 & 170 & 392 \\
\hline AMA-04 & 93 & $\begin{array}{r}24,1 \\
00 \\
\end{array}$ & $\begin{array}{r}3,09 \\
0 \\
\end{array}$ & $\begin{array}{r}43,20 \\
0 \\
\end{array}$ & 2,490 & 157 & $\begin{array}{r}121,0 \\
00 \\
\end{array}$ & 674 & 0 & 0 & 515 \\
\hline \multicolumn{12}{|l|}{ LA ISLA } \\
\hline sample & TDS & $\mathrm{Ca}$ & $\mathrm{Mg}$ & $\mathrm{Na}$ & $\mathrm{K}$ & $\mathrm{Li}$ & $\mathrm{Cl}$ & $\mathrm{SO} 4$ & $\begin{array}{r}\mathrm{CO} \\
3\end{array}$ & $\begin{array}{r}\mathrm{HC} \\
\mathrm{O} 3\end{array}$ & B \\
\hline LIS-RT-001 & 5 & 150 & 78 & 2,000 & 42 & 13 & 3,167 & 666 & 0 & 32 & 0 \\
\hline LIS-RT-002 & 30 & 350 & 450 & $\begin{array}{r}13,00 \\
0\end{array}$ & 880 & 98 & $\begin{array}{r}22,66 \\
1\end{array}$ & 2,118 & 0 & 73 & 10 \\
\hline LIS-RT-003 & 8 & 165 & 125 & 3,000 & 75 & 23 & 4,839 & 857 & 0 & 41 & 0 \\
\hline LIS-RT-004 & 13 & 475 & 183 & 5,200 & 275 & 30 & 8,650 & 1,201 & 0 & 35 & 0 \\
\hline LIS-RT-005 & 15 & 375 & 250 & 6,200 & 375 & 35 & 9,928 & 1,273 & 0 & 42 & 0 \\
\hline LIS-RT-006 & 23 & 425 & 25 & 9,600 & 750 & 73 & $\begin{array}{r}16,20 \\
0\end{array}$ & 1,624 & 0 & 50 & 0 \\
\hline LIS-RT-007 & 123 & 525 & $\begin{array}{r}5,30 \\
0\end{array}$ & $\begin{array}{r}12,00 \\
0\end{array}$ & 8,600 & 851 & $\begin{array}{r}19,3 \\
88\end{array}$ & $\begin{array}{r}14,29 \\
2\end{array}$ & 0 & 188 & 272 \\
\hline LIS-RT-008 & 123 & 500 & $\begin{array}{r}5,00 \\
0\end{array}$ & $\begin{array}{r}130,0 \\
00\end{array}$ & 800 & ח & $\begin{array}{r}196,7 \\
01\end{array}$ & $\begin{array}{r}13,68 \\
7\end{array}$ & 0 & 152 & 268 \\
\hline LIS-RT-009 & 123 & 475 & $\begin{array}{r}4,90 \\
0\end{array}$ & $\begin{array}{r}126,0 \\
00\end{array}$ & 850 & 800 & $\begin{array}{r}180,0 \\
54\end{array}$ & $\begin{array}{r}13,36 \\
2\end{array}$ & 0 & 152 & 262 \\
\hline LIS-RT-010 & 122 & 525 & $\begin{array}{r}5,40 \\
0\end{array}$ & $\begin{array}{r}122,0 \\
0 \mathrm{C}\end{array}$ & ๑, 000 & 875 & $\begin{array}{r}191,3 \\
38\end{array}$ & $\begin{array}{r}14,86 \\
4\end{array}$ & 0 & 190 & 297 \\
\hline LIS-RT-011 & 120 & 525 & $\begin{array}{r}8,30 \\
0\end{array}$ & $\begin{array}{r}110,0 \\
\text { ? }\end{array}$ & $\begin{array}{r}1 r 8,0 \\
00\end{array}$ & $\begin{array}{r}1,15 \\
0\end{array}$ & $\begin{array}{r}189,0 \\
57\end{array}$ & $\begin{array}{r}17,88 \\
4\end{array}$ & 0 & $\begin{array}{r}1,17 \\
3\end{array}$ & 284 \\
\hline LIS-RT-012 & 45 & 195 & 925 & $\begin{array}{r}2,00 \\
-\quad 0 \\
\end{array}$ & 1,575 & 78 & $\begin{array}{r}35,35 \\
1\end{array}$ & 2,346 & 44 & 132 & 26 \\
\hline \multicolumn{12}{|l|}{ AGUILAR } \\
\hline sample & TDS & $\mathrm{Ca}$ & $M \xi$ & $\mathrm{Na}$ & $\mathrm{K}$ & $\mathrm{Li}$ & $\mathrm{Cl}$ & $\mathrm{SO} 4$ & $\begin{array}{r}\mathrm{CO} \\
3 \\
\end{array}$ & $\begin{array}{r}\mathrm{HC} \\
\mathrm{O} 3 \\
\end{array}$ & B \\
\hline AGU-RT-001 & 113 & $\begin{array}{r}55) \\
00\end{array}$ & $\begin{array}{r}\overline{8}, 80 \\
0\end{array}$ & $\begin{array}{r}60,00 \\
0\end{array}$ & 2,600 & 375 & $\begin{array}{r}212,1 \\
26\end{array}$ & 1,382 & 0 & 860 & 692 \\
\hline AGU-RT-002 & 113 & $\begin{array}{r}55,2 \\
0\end{array}$ & $\begin{array}{r}6,90 \\
0\end{array}$ & $\begin{array}{r}60,00 \\
0\end{array}$ & 2,600 & 375 & $\begin{array}{r}206,7 \\
50\end{array}$ & 0 & 0 & 862 & 697 \\
\hline AGU-RT-003 & 15 & $\begin{array}{r}45,0 \\
00 \\
\end{array}$ & $\begin{array}{r}6,10 \\
0 \\
\end{array}$ & $\begin{array}{r}62,00 \\
0 \\
\end{array}$ & 2,600 & 350 & $\begin{array}{r}191,1 \\
25 \\
\end{array}$ & 0 & 0 & $\begin{array}{r}1,02 \\
9 \\
\end{array}$ & 829 \\
\hline \multicolumn{12}{|l|}{ LAS PARINAS } \\
\hline sample & TDS & $\mathrm{Ca}$ & $\mathrm{Mg}$ & $\mathrm{Na}$ & $\mathrm{K}$ & $\mathrm{Li}$ & $\mathrm{Cl}$ & $\mathrm{SO} 4$ & $\begin{array}{r}\mathrm{CO} \\
3 \\
\end{array}$ & $\begin{array}{r}\mathrm{HC} \\
\mathrm{O} 3 \\
\end{array}$ & B \\
\hline LPA-RT-001 & 9 & 105 & 95 & 4,100 & 54 & 10 & 6,058 & 498 & 0 & 211 & 14 \\
\hline LPA-RT-002 & 7 & 100 & 65 & 2,600 & 41 & 7 & 4,431 & 341 & 0 & 209 & 6 \\
\hline LPA-RT-003 & 7 & 113 & 75 & 3,300 & 44 & 8 & 4,786 & 368 & 0 & 217 & 0 \\
\hline LPA-RT-004 & 7 & 130 & 73 & 2,900 & 45 & 7 & 4,672 & 480 & 0 & 87 & 0 \\
\hline LPA-RT-005 & 122 & 725 & $\begin{array}{r}3,20 \\
0\end{array}$ & $\begin{array}{r}100,0 \\
00\end{array}$ & 500 & 350 & $\begin{array}{r}170,1 \\
11\end{array}$ & $\begin{array}{r}12,79 \\
6\end{array}$ & 0 & 580 & 423 \\
\hline LPA-RT-006 & 123 & 625 & $\begin{array}{r}3,60 \\
0 \\
\end{array}$ & $\begin{array}{r}105,0 \\
00 \\
\end{array}$ & 6,000 & 400 & $\begin{array}{r}167,5 \\
84 \\
\end{array}$ & $\begin{array}{r}12,52 \\
2 \\
\end{array}$ & 0 & 651 & 447 \\
\hline \multicolumn{12}{|l|}{ SURIRE } \\
\hline sample & TDS & $\mathrm{Ca}$ & $\mathrm{Mg}$ & $\mathrm{Na}$ & $\mathrm{K}$ & $\mathrm{Li}$ & $\mathrm{Cl}$ & $\mathrm{SO} 4$ & $\begin{array}{r}\mathrm{CO} \\
3 \\
\end{array}$ & $\begin{array}{l}\mathrm{HC} \\
\mathrm{O} 3 \\
\end{array}$ & B \\
\hline SUR0 & 236 & 890 & $\begin{array}{r}3,83 \\
0\end{array}$ & $\begin{array}{r}73,20 \\
0\end{array}$ & $\begin{array}{r}13,20 \\
0\end{array}$ & 540 & $\begin{array}{r}131,3 \\
80\end{array}$ & $\begin{array}{r}11,43 \\
0\end{array}$ & - & & $\begin{array}{r}3,70 \\
0\end{array}$ \\
\hline
\end{tabular}




\begin{tabular}{|c|c|c|c|c|c|c|c|c|c|c|c|}
\hline SUR-22 & 12 & $\begin{array}{r}1,16 \\
0\end{array}$ & 84 & 1,710 & 310 & 8 & 1,800 & 4,060 & 26 & 297 & 544 \\
\hline SUR-23 & 285 & 850 & $\begin{array}{r}2,96 \\
0 \\
\end{array}$ & $\begin{array}{r}93,40 \\
0\end{array}$ & $\begin{array}{r}14,10 \\
0 \\
\end{array}$ & 530 & $\begin{array}{r}155,0 \\
00 \\
\end{array}$ & $\begin{array}{r}11,50 \\
0 \\
\end{array}$ & 0 & 0 & $\begin{array}{r}1,30 \\
0 \\
\end{array}$ \\
\hline \multicolumn{12}{|c|}{ PEDERNALES } \\
\hline sample & TDS & $\mathrm{Ca}$ & $\mathrm{Mg}$ & $\mathrm{Na}$ & $\mathrm{K}$ & $\mathrm{Li}$ & $\mathrm{Cl}$ & $\mathrm{SO} 4$ & $\begin{array}{r}\mathrm{CO} \\
3\end{array}$ & $\begin{array}{c}\mathrm{HC} \\
\mathrm{O} 3\end{array}$ & B \\
\hline PED-26 & 1 & 135 & 43 & 711 & 50 & 3 & 1,250 & 305 & 1 & 127 & 9 \\
\hline PED-27 & 1 & 125 & 42 & 711 & 48 & 3 & 1,180 & 341 & 8 & 126 & 9 \\
\hline PED-28 & 2 & 166 & 58 & 817 & 61 & 3 & 1,450 & 387 & 1 & 92 & 10 \\
\hline PED-29 & 1 & 145 & 46 & 699 & 51 & 3 & 1,260 & 334 & 0 & 103 & 10 \\
\hline \multicolumn{12}{|c|}{ MARICUNGA } \\
\hline sample & TDS & $\mathrm{Ca}$ & $\mathrm{Mg}$ & $\mathrm{Na}$ & $\mathrm{K}$ & $\mathrm{Li}$ & $\mathrm{Cl}$ & $\mathrm{SO} 4$ & $\begin{array}{r}\mathrm{CO} \\
3\end{array}$ & $\begin{array}{c}\mathrm{HC} \\
\mathrm{O} 3\end{array}$ & B \\
\hline MAR-16 & 4 & 165 & 58 & 1,220 & 161 & 11 & $32<0$ & 169 & 0 & 273 & 18 \\
\hline MAR-17 & 2 & 147 & 17 & 543 & 63 & ; & 327 & 175 & 0 & 227 & 11 \\
\hline MAR-19 & 51 & $\begin{array}{r}1,24 \\
0 \\
\end{array}$ & 680 & $\begin{array}{r}16,20 \\
0 \\
\end{array}$ & 1,230 & 92 & $\begin{array}{r}30,80 \\
0 \\
\end{array}$ & 171 & 0 & 0 & 50 \\
\hline \multicolumn{12}{|c|}{ PINTADOS } \\
\hline sample & TDS & $\mathrm{Ca}$ & $\mathrm{Mg}$ & $\mathrm{Na}$ & $n$ & $\mathrm{Li}$ & $\mathrm{Cl}$ & $\mathrm{SO} 4$ & $\begin{array}{r}\mathrm{CO} \\
3 \\
\end{array}$ & $\begin{array}{r}\mathrm{HC} \\
\mathrm{O} 3 \\
\end{array}$ & B \\
\hline PIN-07 & 68 & $\begin{array}{r}4,53 \\
0\end{array}$ & 0 & $\begin{array}{r}19,3 C \\
0\end{array}$ & 2. 10 & 69 & $\begin{array}{r}39,80 \\
0\end{array}$ & 1,900 & 0 & 0 & 21 \\
\hline PIN-16 & 1 & 43 & 9 & 13 & 49 & 1 & 689 & 121 & 1 & 9 & 10 \\
\hline PIN-41 & 23 & 529 & $17 y$ &,- 080 & 696 & 15 & 5,890 & 58 & 11 & 124 & 60 \\
\hline \multicolumn{12}{|c|}{ HUASCO } \\
\hline sample & TDS & $\mathrm{Ca}$ & $\therefore:$ & $\mathrm{Na}$ & $\mathrm{K}$ & $\mathrm{Li}$ & $\mathrm{Cl}$ & $\mathrm{SO} 4$ & $\begin{array}{r}\mathrm{CO} \\
3 \\
\end{array}$ & $\begin{array}{r}\mathrm{HC} \\
\mathrm{O} 3 \\
\end{array}$ & B \\
\hline $\mathrm{HCO} 0$ & 277 & $6^{11}$ & $\begin{array}{r}5,08 \\
0\end{array}$ & $\begin{array}{r}65,00 \\
0\end{array}$ & $\begin{array}{r}13,50 \\
0\end{array}$ & 480 & $\begin{array}{r}112,9 \\
80\end{array}$ & $\begin{array}{r}26,70 \\
0\end{array}$ & - & - & $\begin{array}{r}2,33 \\
3\end{array}$ \\
\hline HCO-6 & 0 & 11 & 8 & 122 & 13 & $<1$ & 82 & 74 & 1 & 2 & 2 \\
\hline HCO-9 & $n$ & 13 & 5 & 45 & 11 & $<1$ & 20 & 156 & 0 & 59 & 1 \\
\hline \multicolumn{12}{|c|}{ COPOSA } \\
\hline sample & & $\mathrm{Ca}$ & $\mathrm{Mg}$ & $\mathrm{Na}$ & $\mathrm{K}$ & $\mathrm{Li}$ & $\mathrm{Cl}$ & $\mathrm{SO} 4$ & $\begin{array}{r}\mathrm{CO} \\
3 \\
\end{array}$ & $\begin{array}{r}\mathrm{HC} \\
\mathrm{O} 3 \\
\end{array}$ & B \\
\hline COP- 03 & $\overline{0}$ & 7 & 4 & 14 & 3 & $<1$ & 10 & 38 & 0 & 9 & 1 \\
\hline COP-07 & 3 & 214 & 163 & 573 & 45 & 2 & 1,010 & 488 & 2 & 79 & 4 \\
\hline COP-08 & 0 & 32 & 18 & 29 & 6 & $<1$ & 28 & 67 & 0 & 146 & 1 \\
\hline COP-09 & 3 & 362 & 53 & 483 & 50 & 1 & 753 & 1,030 & 1 & 111 & 3 \\
\hline COP-11 & 112 & 742 & $\begin{array}{r}4,93 \\
0\end{array}$ & $\begin{array}{r}31,10 \\
0\end{array}$ & 3,080 & 90 & $\begin{array}{r}50,80 \\
0\end{array}$ & $\begin{array}{r}20,40 \\
0\end{array}$ & 16 & 465 & 101 \\
\hline COP-16 & 2 & 119 & 44 & 382 & 18 & 1 & 742 & 235 & 1 & 63 & 2 \\
\hline \multicolumn{12}{|c|}{ MICHINCHA } \\
\hline sample & TDS & $\mathrm{Ca}$ & $\mathrm{Mg}$ & $\mathrm{Na}$ & $\mathrm{K}$ & $\mathrm{Li}$ & $\mathrm{Cl}$ & $\mathrm{SO} 4$ & $\begin{array}{r}\mathrm{CO} \\
3\end{array}$ & $\begin{array}{c}\mathrm{HC} \\
\mathrm{O} 3\end{array}$ & B \\
\hline MIC-08 & 0 & 25 & 19 & 35 & 18 & $<1$ & 18 & - & 0 & 90 & $<1$ \\
\hline MIC-09 & 0 & 32 & 8 & 41 & 16 & $<1$ & 25 & - & 2 & 46 & $<1$ \\
\hline MIC-10 & 1 & 69 & 25 & 33 & 12 & $<1$ & 24 & - & 0 & 25 & $<1$ \\
\hline MIC-11 & 0 & 10 & 3 & 15 & 7 & $<1$ & 10 & - & 0 & 31 & $<1$ \\
\hline
\end{tabular}




\begin{tabular}{|c|c|c|c|c|c|c|c|c|c|c|c|}
\hline MIC-13 & 0 & 20 & 12 & 15 & 6 & $<1$ & 14 & - & 0 & 37 & $<1$ \\
\hline \multicolumn{12}{|c|}{ ALCONCHA } \\
\hline sample & TDS & $\mathrm{Ca}$ & $\mathrm{Mg}$ & $\mathrm{Na}$ & $\mathrm{K}$ & $\mathrm{Li}$ & $\mathrm{Cl}$ & $\mathrm{SO} 4$ & $\begin{array}{r}\mathrm{CO} \\
3\end{array}$ & $\begin{array}{r}\mathrm{HC} \\
\mathrm{O} 3\end{array}$ & B \\
\hline ALC-01 & 1 & 150 & 2 & 97 & 13 & $<1$ & 90 & - & 0 & 87 & 3 \\
\hline \multicolumn{12}{|c|}{ CARCOTE } \\
\hline sample & TDS & $\mathrm{Ca}$ & $\mathrm{Mg}$ & $\mathrm{Na}$ & K & $\mathrm{Li}$ & $\mathrm{Cl}$ & $\mathrm{SO} 4$ & $\begin{array}{r}\mathrm{CO} \\
3 \\
\end{array}$ & $\begin{array}{r}\mathrm{HC} \\
\mathrm{O} 3 \\
\end{array}$ & B \\
\hline CAR-04 & 176 & $\begin{array}{r}12,0 \\
00\end{array}$ & $\begin{array}{r}1,99 \\
0\end{array}$ & $\begin{array}{r}49,50 \\
0\end{array}$ & 2,880 & 136 & $\begin{array}{r}107,0 \\
00\end{array}$ & 1,280 & 6 & 134 & 426 \\
\hline CAR-09 & 2 & 88 & 32 & 593 & 53 & 2 & 1,130 & 35 & 0 & 66 & 5 \\
\hline CAR-16 & 322 & $\begin{array}{r}2,81 \\
0\end{array}$ & $\begin{array}{r}6,85 \\
0\end{array}$ & $\begin{array}{r}101,0 \\
00\end{array}$ & $\begin{array}{r}12,50 \\
0\end{array}$ & 339 & $\begin{array}{r}19,50 \\
0\end{array}$ & 2,440 & 0 & 0 & 0 \\
\hline CAR-19 & 20 & 678 & 352 & 5,680 & 712 & 4 & .690 & 2,320 & 5 & 136 & 66 \\
\hline \multicolumn{12}{|c|}{ ASCOTAN } \\
\hline sample & TDS & $\mathrm{Ca}$ & $\mathrm{Mg}$ & $\mathrm{Na}$ & K & & $\mathrm{Cl}$ & $\mathrm{SO} 4$ & $\begin{array}{r}\mathrm{CO} \\
3 \\
\end{array}$ & $\begin{array}{r}\mathrm{HC} \\
\mathrm{O} 3 \\
\end{array}$ & B \\
\hline ASC0 & 154 & 920 & $\begin{array}{r}5,12 \\
5\end{array}$ & $\begin{array}{r}45,00 \\
0\end{array}$ & 3,530 & 186 & $\begin{array}{r}70,00 \\
0\end{array}$ & $\begin{array}{r}25,00 \\
0\end{array}$ & - & $\begin{array}{r}2,90 \\
0\end{array}$ & $\begin{array}{r}2,52 \\
0\end{array}$ \\
\hline ASC-01 & 3 & 111 & 22 & 679 & $1^{7} 0$ & 8 & 1,160 & 179 & 0 & 225 & 40 \\
\hline ASC-02 & 1 & 58 & 29 & 192 & 26 & 1 & 315 & 105 & 1 & 211 & 3 \\
\hline ASC-03 & 0 & 85 & 21 & 524 & 76 & 6 & 898 & 120 & 0 & 204 & 30 \\
\hline ASC-04 & 2 & 131 & 31 & 50 & 65 & 5 & 1,080 & 191 & 1 & 67 & 7 \\
\hline ASC-15 & 2 & 87 & 22 & 536 & 77 & 6 & 888 & 124 & 0 & 200 & 30 \\
\hline ASC-16 & 0 & 19 & 4 & 96 & 15 & 1 & 107 & 63 & 0 & 90 & 4 \\
\hline ASC-17 & 5 & 205 & 43 & 1,110 & 113 & 5 & 1,680 & 672 & 3 & 714 & 58 \\
\hline ASC-41 & 118 & $\begin{array}{r}1,17 \\
0\end{array}$ & $\begin{array}{r}41 \\
1\end{array}$ & $\begin{array}{r}35,40 \\
0\end{array}$ & 4,890 & 245 & $\begin{array}{r}58,60 \\
0\end{array}$ & $\begin{array}{r}12,20 \\
0\end{array}$ & 40 & 958 & $\begin{array}{r}1,03 \\
0\end{array}$ \\
\hline ASC-47 & 3 & 13 & -31 & 860 & 96 & 4 & 1,080 & 194 & 80 & 365 & 21 \\
\hline \multicolumn{12}{|c|}{ ATACAMA } \\
\hline sample & TDS & $\mathrm{ra}$ & $\mathrm{Mg}$ & $\mathrm{Na}$ & $\mathrm{K}$ & $\mathrm{Li}$ & $\mathrm{Cl}$ & $\mathrm{SO} 4$ & $\begin{array}{r}\mathrm{CO} \\
3\end{array}$ & $\begin{array}{r}\mathrm{HC} \\
\mathrm{O} 3\end{array}$ & B \\
\hline ATA0 & 370 & 520 & $\begin{array}{r}6,13 \\
0\end{array}$ & $\begin{array}{r}103,0 \\
00\end{array}$ & $\begin{array}{r}12,90 \\
0\end{array}$ & 760 & $\begin{array}{r}193,1 \\
00\end{array}$ & $\begin{array}{r}16,14 \\
0\end{array}$ & - & 560 & $\begin{array}{r}1,70 \\
5\end{array}$ \\
\hline ATAdo & 3,5 & 300 & $\begin{array}{r}8,50 \\
0\end{array}$ & $\begin{array}{r}98,00 \\
0\end{array}$ & $\begin{array}{r}19,50 \\
0\end{array}$ & $\begin{array}{r}1,20 \\
0\end{array}$ & $\begin{array}{r}182,8 \\
00\end{array}$ & $\begin{array}{r}25,50 \\
0\end{array}$ & - & 220 & $\begin{array}{r}1,67 \\
3\end{array}$ \\
\hline ATA & 370 & 450 & $\begin{array}{r}9,65 \\
0\end{array}$ & $\begin{array}{r}91,10 \\
0\end{array}$ & $\begin{array}{r}23,60 \\
0\end{array}$ & $\begin{array}{r}1,57 \\
0\end{array}$ & $\begin{array}{r}189,5 \\
00\end{array}$ & $\begin{array}{r}15,90 \\
0\end{array}$ & - & 230 & 440 \\
\hline Do1 & 310 & $\begin{array}{r}1,10 \\
0\end{array}$ & $\begin{array}{r}6,35 \\
0\end{array}$ & $\begin{array}{r}85,80 \\
0\end{array}$ & $\begin{array}{r}13,00 \\
0\end{array}$ & 940 & $\begin{array}{r}163,9 \\
00\end{array}$ & 8,540 & 0 & 280 & 360 \\
\hline Do2 & 190 & 900 & $\begin{array}{r}5,33 \\
0\end{array}$ & $\begin{array}{r}45,10 \\
0\end{array}$ & 9,000 & 520 & $\begin{array}{r}83,78 \\
0\end{array}$ & $\begin{array}{r}18,17 \\
0\end{array}$ & 0 & 240 & 360 \\
\hline Do3 & 73 & 360 & $\begin{array}{r}1,81 \\
0\end{array}$ & $\begin{array}{r}18,22 \\
0\end{array}$ & 4,220 & 290 & $\begin{array}{r}36,75 \\
0\end{array}$ & 3,430 & 0 & 320 & 100 \\
\hline Do4 & 62 & $\begin{array}{r}1,08 \\
0\end{array}$ & $\begin{array}{r}1,93 \\
0\end{array}$ & $\begin{array}{r}14,84 \\
0\end{array}$ & 2,900 & 190 & $\begin{array}{r}27,50 \\
0\end{array}$ & 7,900 & 0 & 100 & 88 \\
\hline Do5 & 40 & $\begin{array}{r}1,06 \\
0\end{array}$ & 750 & $\begin{array}{r}10,28 \\
0\end{array}$ & 1,690 & 130 & $\begin{array}{r}20,30 \\
0\end{array}$ & 2,160 & 0 & 92 & 61 \\
\hline ATA-05 & 2 & 136 & 60 & 520 & 50 & 4 & 959 & 271 & 1 & 254 & 20 \\
\hline ATA-22 & 4 & 151 & 128 & 1,070 & 196 & 13 & 1,880 & 552 & 1 & 429 & 13 \\
\hline
\end{tabular}




\begin{tabular}{|c|c|c|c|c|c|c|c|c|c|c|c|}
\hline sample & TDS & $\mathrm{Ca}$ & $\mathrm{Mg}$ & $\mathrm{Na}$ & K & $\mathrm{Li}$ & $\mathrm{Cl}$ & $\mathrm{SO} 4$ & $\begin{array}{r}\mathrm{CO} \\
3 \\
\end{array}$ & $\begin{array}{c}\mathrm{HC} \\
\mathrm{O} 3 \\
\end{array}$ & B \\
\hline IMI-01 & 1 & 39 & 3 & 132 & 11 & $<1$ & 96 & 233 & 1 & 28 & 2 \\
\hline IMI-03 & 6 & 593 & 52 & 1,460 & 73 & 73 & 1,970 & 1,900 & 0 & 68 & 6 \\
\hline IMI-04 & 2 & 11 & 7 & $\begin{array}{r}30,40 \\
0\end{array}$ & 19 & 1 & 1,000 & 60 & 13 & 73 & 2 \\
\hline IMI-8D & 12 & 642 & 66 & 3,800 & 94 & 2 & 6,430 & 1,010 & 0 & 66 & 8 \\
\hline \multicolumn{12}{|c|}{ PUNTA NEGRA } \\
\hline sample & TDS & $\mathrm{Ca}$ & $\mathrm{Mg}$ & $\mathrm{Na}$ & K & $\mathrm{Li}$ & $\mathrm{Cl}$ & $\mathrm{SO} 4$ & $\begin{array}{r}\mathrm{CO} \\
3 \\
\end{array}$ & $\begin{array}{r}\mathrm{HC} \\
\mathrm{O} 3 \\
\end{array}$ & B \\
\hline PUN-08 & 7 & 78 & 24 & 2,420 & 140 & 3 & 3,980 & 101 & 1 & 70 & 2 \\
\hline PUN-16 & 3 & 9 & 53 & 653 & 89 & 3 & 1,560 & 420 & 0 & 40 & 20 \\
\hline PUN-18 & 3 & 158 & 24 & 791 & 104 & 2 & 1,440 & 240 & 0 & 6 & 10 \\
\hline PUN-19 & 1 & 19 & 3 & 127 & 15 & $<1$ & 172 & 30 & 5 & 79 & 1 \\
\hline PUN-20 & 1 & 3 & 0 & 175 & 8 & $<1$ & 152 & 37 & 30 & 129 & 0 \\
\hline PUN-24 & 0 & 31 & 2 & 139 & 9 & $\leq 1$ & 244 & 37 & 1 & 13 & 0 \\
\hline \multicolumn{12}{|c|}{ IGNORADOS } \\
\hline sample & TDS & $\mathrm{Ca}$ & $\mathrm{Mg}$ & $\mathrm{Na}$ & V & $\mathrm{Li}$ & $\mathrm{Cl}$ & $\mathrm{SO} 4$ & $\begin{array}{r}\mathrm{CO} \\
3 \\
\end{array}$ & $\begin{array}{r}\mathrm{HC} \\
\mathrm{O} 3 \\
\end{array}$ & B \\
\hline IGN-04 & 10 & 485 & 445 & 342 & 342 & 1 & 444 & 6,490 & 0 & 0 & 18 \\
\hline IGN-05 & 13 & 505 & 707 & 637 & 637 & 2 & 1,410 & 7,300 & 0 & 0 & 29 \\
\hline \multicolumn{12}{|c|}{ LA AZUFRERA } \\
\hline sample & TDS & $\mathrm{Ca}$ & $\mathrm{Mg}$ & $\mathrm{Na}$ & K & $\mathrm{Li}$ & $\mathrm{Cl}$ & $\mathrm{SO} 4$ & $\begin{array}{r}\mathrm{CO} \\
3\end{array}$ & $\begin{array}{c}\mathrm{HC} \\
\mathrm{O} 3\end{array}$ & B \\
\hline AZU0 & 400 & 88 & $\begin{array}{r}48,6 \\
17\end{array}$ & $\begin{array}{r}\iota^{7} 00 \\
0\end{array}$ & $\begin{array}{r}14,96 \\
0\end{array}$ & 86 & $\begin{array}{r}172,1 \\
30\end{array}$ & $\begin{array}{r}87,99 \\
0\end{array}$ & - & 0 & 740 \\
\hline AZU-07 & 1 & 117 & 9 & 34 & 11 & $<1$ & 157 & 148 & 0 & 29 & 0 \\
\hline \multicolumn{12}{|l|}{ JAMA } \\
\hline sample & TDS & $\mathrm{Ca}_{\mathfrak{a}}$ & $\mathrm{Mg}$ & $\mathrm{Na}$ & K & $\mathrm{Li}$ & $\mathrm{Cl}$ & $\mathrm{SO} 4$ & $\begin{array}{r}\mathrm{CO} \\
3 \\
\end{array}$ & $\begin{array}{r}\mathrm{HC} \\
\mathrm{O} 3 \\
\end{array}$ & B \\
\hline JA1 & $?$ & $\begin{array}{r}78 \\
0\end{array}$ & 402 & 2,004 & 201 & 6 & 2,560 & 7,009 & 0 & 349 & 539 \\
\hline JA2 & 7 & 991 & 243 & 2,860 & 343 & 11 & 2,627 & 4,587 & 0 & 387 & $\begin{array}{r}3,07 \\
0\end{array}$ \\
\hline JA3 & 6 & 131 & 17 & 3,523 & 210 & 10 & 6,170 & 2,051 & 0 & 332 & 236 \\
\hline JA4 & 6 & 122 & 48 & 3,422 & 344 & 2 & 4,927 & 2,537 & 0 & 234 & 493 \\
\hline JA5 & 6 & 65 & 47 & 4,183 & 297 & 2 & 5,868 & 1,219 & 0 & 263 & 239 \\
\hline JA6 & 91 & 647 & 469 & $\begin{array}{r}60,43 \\
2\end{array}$ & 4,591 & 262 & $\begin{array}{r}97,01 \\
7\end{array}$ & $\begin{array}{r}14,61 \\
5\end{array}$ & 0 & 286 & $\begin{array}{r}1,42 \\
1\end{array}$ \\
\hline JA7 & 6 & 122 & 48 & 3,475 & 344 & 2 & 4,929 & 2,535 & 0 & 341 & 493 \\
\hline JA8 & 6 & 122 & 47 & 3,482 & 344 & 2 & 4,930 & 2,541 & 0 & 344 & 494 \\
\hline JA9 & 90 & 647 & 467 & $\begin{array}{r}60,42 \\
7\end{array}$ & 3,356 & 262 & $\begin{array}{r}97,01 \\
8\end{array}$ & $\begin{array}{r}14,61 \\
6\end{array}$ & 0 & 282 & $\begin{array}{r}1,42 \\
1\end{array}$ \\
\hline JA10 & 92 & 646 & 492 & $\begin{array}{r}60,43 \\
7 \\
\end{array}$ & 4,658 & 261 & $\begin{array}{r}97,01 \\
7 \\
\end{array}$ & $\begin{array}{r}14,61 \\
6 \\
\end{array}$ & 0 & 272 & $\begin{array}{r}1,42 \\
2 \\
\end{array}$ \\
\hline \multicolumn{12}{|c|}{ OLAROZ } \\
\hline sample & TDS & $\mathrm{Ca}$ & $\mathrm{Mg}$ & $\mathrm{Na}$ & K & $\mathrm{Li}$ & $\mathrm{Cl}$ & $\mathrm{SO} 4$ & $\begin{array}{r}\mathrm{CO} \\
3 \\
\end{array}$ & $\begin{array}{r}\mathrm{HC} \\
\mathrm{O} 3 \\
\end{array}$ & B \\
\hline OL1 & 157 & 584 & $\begin{array}{r}1,53 \\
9\end{array}$ & $\begin{array}{r}112,1 \\
91\end{array}$ & 5,051 & 771 & $\begin{array}{r}181,7 \\
49\end{array}$ & 9,678 & 0 & 421 & $\begin{array}{r}2,09 \\
0\end{array}$ \\
\hline
\end{tabular}




\begin{tabular}{|c|c|c|c|c|c|c|c|c|c|c|c|}
\hline OL2 & 158 & 529 & $\begin{array}{r}1,98 \\
1\end{array}$ & $\begin{array}{r}112,1 \\
90\end{array}$ & 5,504 & 968 & $\begin{array}{r}181,0 \\
03\end{array}$ & $\begin{array}{r}10,22 \\
2\end{array}$ & 0 & 419 & $\begin{array}{r}2,09 \\
0\end{array}$ \\
\hline OL3 & 155 & 526 & $\begin{array}{r}1,97 \\
2\end{array}$ & $\begin{array}{r}107,6 \\
54\end{array}$ & 6,019 & $\begin{array}{r}1,00 \\
7\end{array}$ & $\begin{array}{r}179,6 \\
27\end{array}$ & $\begin{array}{r}10,19 \\
2\end{array}$ & 0 & 435 & $\begin{array}{r}2,30 \\
2\end{array}$ \\
\hline OL4 & 157 & 481 & $\begin{array}{r}2,30 \\
1\end{array}$ & $\begin{array}{r}107,9 \\
56\end{array}$ & 7,984 & $\begin{array}{r}1,20 \\
7\end{array}$ & $\begin{array}{r}180,8 \\
37\end{array}$ & 8,982 & 0 & 328 & $\begin{array}{r}3,17 \\
6\end{array}$ \\
\hline OL5 & 137 & 448 & $\begin{array}{r}2,18 \\
3\end{array}$ & $\begin{array}{r}69,85 \\
5\end{array}$ & 6,563 & $\begin{array}{r}1,09 \\
2\end{array}$ & $\begin{array}{r}175,6 \\
95\end{array}$ & $\begin{array}{r}10,58 \\
5\end{array}$ & 0 & 343 & $\begin{array}{r}2,51 \\
1\end{array}$ \\
\hline OL6 & 153 & 496 & $\begin{array}{r}2,27 \\
6\end{array}$ & $\begin{array}{r}79,67 \\
0\end{array}$ & 7,870 & $\begin{array}{r}1,21 \\
3\end{array}$ & $\begin{array}{r}187,0 \\
41\end{array}$ & $\begin{array}{r}10,01 \\
5\end{array}$ & 0 & 366 & $\begin{array}{r}2,25 \\
1\end{array}$ \\
\hline OL7 & 158 & 513 & $\begin{array}{r}1,98 \\
8\end{array}$ & $\begin{array}{r}107,7 \\
59\end{array}$ & 5,179 & 868 & $\begin{array}{r}176,3 \\
45\end{array}$ & 9,856 & 0 & 331 & $\begin{array}{r}2,42 \\
2\end{array}$ \\
\hline OL8 & 160 & 537 & $\begin{array}{r}2,18 \\
6\end{array}$ & $\begin{array}{r}107,0 \\
69\end{array}$ & 5,501 & $\begin{array}{r}1,09 \\
3\end{array}$ & $\begin{array}{r}184,9 \\
87\end{array}$ & $\begin{array}{r}10,20 \\
3\end{array}$ & 0 & 280 & $\begin{array}{r}3,03 \\
7\end{array}$ \\
\hline OL9 & 159 & 447 & $\begin{array}{r}1,62 \\
8\end{array}$ & $\begin{array}{r}112,3 \\
32\end{array}$ & 6,003 & $\begin{array}{r}1,06 \\
1\end{array}$ & $\begin{array}{r}179,0 \\
91\end{array}$ & $\begin{array}{r}10,65 \\
8\end{array}$ & 0 & 247 & $\begin{array}{r}2,80 \\
0\end{array}$ \\
\hline OL10 & 145 & 598 & $\begin{array}{r}1,97 \\
0\end{array}$ & $\begin{array}{r}71,78 \\
3\end{array}$ & 6,569 & 86. & ${ }^{\prime} \begin{array}{r}1,6 \\
05\end{array}$ & $\begin{array}{r}10,37 \\
4\end{array}$ & 0 & 266 & $\begin{array}{r}2,65 \\
5\end{array}$ \\
\hline \multicolumn{12}{|c|}{ CAUCHARI } \\
\hline sample & TDS & $\mathrm{Ca}$ & $\mathrm{Mg}$ & $\mathrm{Na}$ & & $\mathrm{Li}$ & $\mathrm{Cl}$ & $\mathrm{SO} 4$ & $\begin{array}{r}\mathrm{CO} \\
3\end{array}$ & $\begin{array}{r}\mathrm{HC} \\
\mathrm{O} 3 \\
\end{array}$ & B \\
\hline CA1 & 97 & 556 & $\begin{array}{r}1,85 \\
1\end{array}$ & $\begin{array}{r}69,82 \\
6\end{array}$ & $2,>76$ & 535 & $\begin{array}{r}108,0 \\
14\end{array}$ & 9,060 & 0 & 279 & $\begin{array}{r}1,33 \\
7\end{array}$ \\
\hline $\mathrm{CA} 2$ & 92 & 764 & $\begin{array}{r}1,50 \\
9\end{array}$ & $\begin{array}{r}58,0= \\
2\end{array}$ & $2: 14$ & 442 & $\begin{array}{r}102,2 \\
11\end{array}$ & $\begin{array}{r}14,47 \\
1\end{array}$ & 0 & 355 & $\begin{array}{r}2,19 \\
0\end{array}$ \\
\hline $\mathrm{CA} 3$ & 124 & 603 & $\begin{array}{r}1,67 \\
U\end{array}$ & $\begin{array}{r}\text { ४. } 70 \\
9\end{array}$ & 8,594 & $\begin{array}{r}1,74 \\
0\end{array}$ & $\begin{array}{r}130,4 \\
06\end{array}$ & $\begin{array}{r}11,95 \\
8\end{array}$ & 0 & 490 & $\begin{array}{r}2,83 \\
4\end{array}$ \\
\hline CA4 & 139 & 477 & $\begin{array}{r}1,59 \\
1\end{array}$ & $\begin{array}{r}\text { l, } 3 \\
47\end{array}$ & 4,769 & 713 & $\begin{array}{r}149,8 \\
18\end{array}$ & $\begin{array}{r}16,35 \\
6\end{array}$ & 0 & 461 & $\begin{array}{r}2,30 \\
4\end{array}$ \\
\hline CA5 & 144 & 599 & 2. . 1 & $\begin{array}{r}104,5 \\
15 \\
\end{array}$ & 4,733 & 873 & $\begin{array}{r}163,8 \\
86 \\
\end{array}$ & 9,685 & 0 & 623 & $\begin{array}{r}2,12 \\
6 \\
\end{array}$ \\
\hline \multicolumn{12}{|c|}{ SALINAS GRANDES } \\
\hline sample & TDS & $\mathrm{C}^{2}$ & $\mathrm{Mg}$ & $\mathrm{Na}$ & $\mathrm{K}$ & $\mathrm{Li}$ & $\mathrm{Cl}$ & $\mathrm{SO} 4$ & $\begin{array}{r}\mathrm{CO} \\
3\end{array}$ & $\begin{array}{c}\mathrm{HC} \\
\mathrm{O} 3\end{array}$ & $\mathrm{~B}$ \\
\hline SG1 & & 077 & 115 & 6,413 & 694 & 25 & $\begin{array}{r}10,20 \\
3\end{array}$ & 3,982 & 0 & 375 & 527 \\
\hline SG2 & & $\begin{array}{r}1,30 \\
7\end{array}$ & 803 & $\begin{array}{r}86,37 \\
5\end{array}$ & 3,325 & 218 & $\begin{array}{r}140,6 \\
86\end{array}$ & 1,746 & 0 & 342 & 509 \\
\hline SG3 & 119 & $\begin{array}{r}1,46 \\
2\end{array}$ & $\begin{array}{r}1,01 \\
7\end{array}$ & $\begin{array}{r}84,71 \\
8\end{array}$ & 3,498 & 244 & $\begin{array}{r}141,3 \\
54\end{array}$ & 1,573 & 0 & 344 & 542 \\
\hline SG4 & 121 & $\begin{array}{r}1,44 \\
2\end{array}$ & $\begin{array}{r}1,13 \\
0\end{array}$ & $\begin{array}{r}86,81 \\
7\end{array}$ & 3,762 & 270 & $\begin{array}{r}140,2 \\
66\end{array}$ & 2,174 & 0 & 339 & 444 \\
\hline SG5 & 116 & $\begin{array}{r}1,90 \\
6\end{array}$ & $\begin{array}{r}1,30 \\
1\end{array}$ & $\begin{array}{r}77,46 \\
8\end{array}$ & 4,521 & 382 & $\begin{array}{r}140,4 \\
12\end{array}$ & 1,908 & 0 & 256 & 452 \\
\hline SG6 & 116 & $\begin{array}{r}1,47 \\
2\end{array}$ & 843 & $\begin{array}{r}79,32 \\
7\end{array}$ & 3,651 & 241 & $\begin{array}{r}139,3 \\
02\end{array}$ & 2,388 & 0 & 278 & 342 \\
\hline SG7 & 116 & $\begin{array}{r}2,11 \\
9\end{array}$ & $\begin{array}{r}2,28 \\
9\end{array}$ & $\begin{array}{r}67,95 \\
4\end{array}$ & 8,149 & $\begin{array}{r}1,01 \\
8\end{array}$ & $\begin{array}{r}139,0 \\
71\end{array}$ & 1,441 & 0 & 230 & 361 \\
\hline SG8 & 119 & $\begin{array}{r}1,43 \\
2\end{array}$ & 924 & $\begin{array}{r}80,24 \\
6\end{array}$ & 3,890 & 247 & $\begin{array}{r}139,7 \\
97\end{array}$ & 1,959 & 0 & 351 & 309 \\
\hline SG9 & 118 & $\begin{array}{r}1,39 \\
5\end{array}$ & $\begin{array}{r}1,02 \\
2\end{array}$ & $\begin{array}{r}85,69 \\
3\end{array}$ & 4,668 & 325 & $\begin{array}{r}137,8 \\
46\end{array}$ & 1,900 & 0 & 368 & 512 \\
\hline SG10 & 116 & $\begin{array}{r}1,78 \\
7\end{array}$ & $\begin{array}{r}1,23 \\
3\end{array}$ & $\begin{array}{r}77,53 \\
9\end{array}$ & 5,196 & 352 & $\begin{array}{r}137,6 \\
91\end{array}$ & 1,751 & 0 & 260 & 469 \\
\hline
\end{tabular}




\begin{tabular}{|c|c|c|c|c|c|c|c|c|c|c|c|}
\hline \multicolumn{12}{|c|}{ GUAYATAYOC } \\
\hline sample & TDS & $\mathrm{Ca}$ & $\mathrm{Mg}$ & $\mathrm{Na}$ & K & $\mathrm{Li}$ & $\mathrm{Cl}$ & $\mathrm{SO} 4$ & $\begin{array}{r}\mathrm{CO} \\
3 \\
\end{array}$ & $\begin{array}{c}\mathrm{HC} \\
\mathrm{O} 3 \\
\end{array}$ & B \\
\hline GG3 & 48 & $\begin{array}{r}2,08 \\
4\end{array}$ & 292 & $\begin{array}{r}20,00 \\
0\end{array}$ & 8070 & 45 & $\begin{array}{r}58,50 \\
0\end{array}$ & 7,560 & 0 & 384 & 310 \\
\hline GQ0 & 86 & $\begin{array}{r}1,38 \\
2\end{array}$ & 134 & $\begin{array}{r}32,40 \\
0\end{array}$ & $\begin{array}{r}21,00 \\
0\end{array}$ & 125 & $\begin{array}{r}252,8 \\
00\end{array}$ & $\begin{array}{r}13,00 \\
0\end{array}$ & 0 & 286 & 450 \\
\hline GG4 & 81 & $\begin{array}{r}1,27 \\
0 \\
\end{array}$ & 123 & $\begin{array}{r}31,70 \\
0 \\
\end{array}$ & $\begin{array}{r}20,87 \\
0 \\
\end{array}$ & 117 & $\begin{array}{r}245,0 \\
90 \\
\end{array}$ & $\begin{array}{r}13,50 \\
0 \\
\end{array}$ & 0 & 276 & 321 \\
\hline \multicolumn{12}{|c|}{ CENTENARIO } \\
\hline sample & TDS & $\mathrm{Ca}$ & $\mathrm{Mg}$ & $\mathrm{Na}$ & K & $\mathrm{Li}$ & $\mathrm{Cl}$ & $\mathrm{SO} 4$ & $\begin{array}{r}\mathrm{CO} \\
3 \\
\end{array}$ & $\begin{array}{r}\mathrm{HC} \\
\mathrm{O} 3 \\
\end{array}$ & B \\
\hline CE0 & 343 & 320 & $\begin{array}{r}7,55 \\
0\end{array}$ & $\begin{array}{r}112,3 \\
00\end{array}$ & 8,170 & $\begin{array}{r}1,02 \\
0\end{array}$ & $\begin{array}{r}192,7 \\
00\end{array}$ & $\begin{array}{r}19,98 \\
0\end{array}$ & - & - & $\begin{array}{r}3,76 \\
5\end{array}$ \\
\hline CE1 & 26 & 831 & 916 & 6,752 & 966 & 65 & $\begin{array}{r}1.59 \\
5\end{array}$ & 2,960 & 0 & 498 & 365 \\
\hline CE2 & 26 & 508 & 604 & 7,134 & 843 & & $\begin{array}{r}1,27 \\
6\end{array}$ & 3,056 & 0 & 496 & 277 \\
\hline CE3 & 41 & 395 & $\begin{array}{r}1,19 \\
6\end{array}$ & $\begin{array}{r}10,61 \\
3\end{array}$ & 2,860 & 106 & $\begin{array}{r}17,13 \\
3\end{array}$ & $\begin{array}{r}12,46 \\
1\end{array}$ & 0 & 322 & 434 \\
\hline CE4 & 45 & 842 & $\begin{array}{r}1,21 \\
7\end{array}$ & $\begin{array}{r}11,76 \\
7\end{array}$ & $2,91^{1}$ & 133 & $\begin{array}{r}18,46 \\
6\end{array}$ & $\begin{array}{r}12,66 \\
3\end{array}$ & 0 & 343 & 581 \\
\hline CE5 & 49 & 619 & $\begin{array}{r}2,27 \\
7 \\
\end{array}$ & $\begin{array}{r}10,45 \\
-0 \\
\end{array}$ & 3, 25 & 377 & $\begin{array}{r}21,49 \\
3 \\
\end{array}$ & $\begin{array}{r}12,18 \\
4 \\
\end{array}$ & 0 & 494 & 402 \\
\hline \multicolumn{12}{|c|}{ DIABLILLOS } \\
\hline sample & TDS & $\mathrm{Ca}$ & $\mathrm{Mg}$ & $\mathrm{Na}$ & K & $\mathrm{Li}$ & $\mathrm{Cl}$ & $\mathrm{SO} 4$ & $\begin{array}{r}\mathrm{CO} \\
3 \\
\end{array}$ & $\begin{array}{r}\mathrm{HC} \\
\mathrm{O} 3 \\
\end{array}$ & B \\
\hline DI1 & 38 & 791 & $\begin{array}{r}1,0^{\circ} \\
1\end{array}$ & 9,533 & 746 & 47 & $\begin{array}{r}21,89 \\
7\end{array}$ & 3,541 & 0 & 230 & 360 \\
\hline DI2 & 26 & 79 & $\begin{array}{r}11 \% \\
1\end{array}$ & 6,943 & 687 & 81 & $\begin{array}{r}15,04 \\
1\end{array}$ & 2,715 & 0 & 376 & 584 \\
\hline DI3 & 78 & $\begin{array}{r}1.40 \\
?\end{array}$ & 933 & $\begin{array}{r}21,53 \\
5\end{array}$ & 7,876 & 235 & $\begin{array}{r}38,27 \\
0\end{array}$ & 9,587 & 0 & 351 & 808 \\
\hline DI4 & 81 & $\begin{array}{r}1,+8 \\
6 \\
\end{array}$ & 964 & $\begin{array}{r}21,78 \\
4 \\
\end{array}$ & 6,370 & 357 & $\begin{array}{r}37,73 \\
1 \\
\end{array}$ & $\begin{array}{r}11,61 \\
8 \\
\end{array}$ & 0 & 334 & 614 \\
\hline \multicolumn{12}{|c|}{ HOMBRE MUERTO } \\
\hline sample & TIS & $\mathrm{Ca}$ & $\mathrm{Mg}$ & $\mathrm{Na}$ & K & $\mathrm{Li}$ & $\mathrm{Cl}$ & $\mathrm{SO} 4$ & $\begin{array}{r}\mathrm{CO} \\
3 \\
\end{array}$ & $\begin{array}{r}\mathrm{HC} \\
\mathrm{O} 3 \\
\end{array}$ & B \\
\hline MHO & 341 & $\begin{array}{r}1,00 \\
0\end{array}$ & 268 & $\begin{array}{r}121,9 \\
00\end{array}$ & 9,340 & 914 & $\begin{array}{r}194,8 \\
00\end{array}$ & $\begin{array}{r}11,10 \\
0\end{array}$ & - & - & $\begin{array}{r}1,45 \\
5\end{array}$ \\
\hline HM1 & 31 & 792 & 916 & 8,197 & 2,984 & 114 & $\begin{array}{r}18,76 \\
6\end{array}$ & 1,017 & 0 & 133 & 377 \\
\hline HM2 & 33 & 410 & 678 & 8,871 & 4,310 & 85 & $\begin{array}{r}19,49 \\
0\end{array}$ & 1,216 & 0 & 204 & 538 \\
\hline HM3 & 194 & $\begin{array}{r}1,16 \\
2\end{array}$ & $\begin{array}{r}1,11 \\
4\end{array}$ & $\begin{array}{r}64,92 \\
7\end{array}$ & 6,430 & 966 & $\begin{array}{r}137,9 \\
10\end{array}$ & 1,284 & 0 & 62 & $\begin{array}{r}1,32 \\
3\end{array}$ \\
\hline HM4 & 205 & 592 & 833 & $\begin{array}{r}72,48 \\
4\end{array}$ & 4,022 & 674 & $\begin{array}{r}139,4 \\
09\end{array}$ & 1,312 & 0 & 321 & 515 \\
\hline HM5 & 196 & 874 & $\begin{array}{r}1,91 \\
5 \\
\end{array}$ & $\begin{array}{r}62,40 \\
0 \\
\end{array}$ & 5,660 & $\begin{array}{r}1,01 \\
3 \\
\end{array}$ & $\begin{array}{r}125,3 \\
13 \\
\end{array}$ & 934 & 0 & 105 & $\begin{array}{r}149 \\
0 \\
\end{array}$ \\
\hline \multicolumn{12}{|c|}{ INCAHUASI } \\
\hline sample & TDS & $\mathrm{Ca}$ & $\mathrm{Mg}$ & $\mathrm{Na}$ & $\mathrm{K}$ & $\mathrm{Li}$ & $\mathrm{Cl}$ & $\mathrm{SO} 4$ & $\mathrm{CO}$ & $\mathrm{HC}$ & $\mathrm{B}$ \\
\hline
\end{tabular}




\begin{tabular}{|c|c|c|c|c|c|c|c|c|c|c|c|}
\hline & & & & & & & & & 3 & $\mathrm{O} 3$ & \\
\hline IN1 & 48 & $\begin{array}{r}1,28 \\
4\end{array}$ & 5283 & 7,360 & 2,754 & 22 & $\begin{array}{r}32,63 \\
1\end{array}$ & 362 & 0 & 315 & 114 \\
\hline $\mathrm{IN} 2$ & 69 & 976 & $\begin{array}{r}10,3 \\
76\end{array}$ & 6,548 & 6,896 & 82 & $\begin{array}{r}48,67 \\
5\end{array}$ & 930 & 0 & 75 & 558 \\
\hline IN3 & 100 & $\begin{array}{r}1,19 \\
4\end{array}$ & $\begin{array}{r}15,8 \\
94\end{array}$ & $\begin{array}{r}12,34 \\
4\end{array}$ & 4,012 & 132 & $\begin{array}{r}72,91 \\
3\end{array}$ & 678 & 0 & 15 & 510 \\
\hline IN4 & 107 & 988 & $\begin{array}{r}14,6 \\
87\end{array}$ & $\begin{array}{r}11,78 \\
2\end{array}$ & 7,130 & 145 & $\begin{array}{r}74,35 \\
3\end{array}$ & 736 & 0 & 44 & 570 \\
\hline IN5 & 86 & $\begin{array}{r}1,07 \\
4 \\
\end{array}$ & 9828 & $\begin{array}{r}10,49 \\
1 \\
\end{array}$ & 7,732 & 96 & $\begin{array}{r}61,34 \\
5 \\
\end{array}$ & 855 & 0 & 276 & 427 \\
\hline \multicolumn{12}{|c|}{ PASTOS GRANDES (PUNA) } \\
\hline sample & TDS & $\mathrm{Ca}$ & $\mathrm{Mg}$ & $\mathrm{Na}$ & $\mathrm{K}$ & $\mathrm{Li}$ & $\mathrm{Cl}$ & $\mathrm{SO} 4$ & $\begin{array}{r}\mathrm{CO} \\
3\end{array}$ & $\begin{array}{c}\mathrm{HC} \\
\mathrm{O} 3\end{array}$ & B \\
\hline PG0 & 333 & 740 & $\begin{array}{r}2,98 \\
0\end{array}$ & $\begin{array}{r}118,2 \\
00\end{array}$ & 4,730 & 440 & $\begin{array}{r}78,7 \\
00\end{array}$ & $\begin{array}{r}26,08 \\
0\end{array}$ & - & - & $\begin{array}{r}2,22 \\
0\end{array}$ \\
\hline PG1 & 154 & 766 & $\begin{array}{r}3,78 \\
5\end{array}$ & $\begin{array}{r}50,22 \\
0\end{array}$ & 919 & & $\begin{array}{r}0,05 \\
3\end{array}$ & 968 & 0 & 822 & 702 \\
\hline PG2 & 227 & 745 & $\begin{array}{r}2,43 \\
1\end{array}$ & $\begin{array}{r}80,73 \\
2\end{array}$ & 652 & 510 & $\begin{array}{r}161,3 \\
90\end{array}$ & 970 & 0 & 896 & 784 \\
\hline PG3 & 157 & 512 & $\begin{array}{r}4,47 \\
9\end{array}$ & $\begin{array}{r}50,67 \\
3\end{array}$ & $5,5 u^{6}$ & 410 & $\begin{array}{r}102,8 \\
50\end{array}$ & 970 & 0 & 980 & 300 \\
\hline PG4 & 158 & 580 & $\begin{array}{r}5,64 \\
6\end{array}$ & $\begin{array}{r}49,77 \\
2\end{array}$ & נ, 90 & 305 & $\begin{array}{r}101,0 \\
60\end{array}$ & 943 & 0 & 955 & 455 \\
\hline PG5 & 158 & 498 & $\begin{array}{r}5,61 \\
1 \\
\end{array}$ & $\begin{array}{r}11, .5 \\
-\quad 4 \\
\end{array}$ & 5,914 & 857 & $\begin{array}{r}91,50 \\
5 \\
\end{array}$ & $\begin{array}{r}14,90 \\
3 \\
\end{array}$ & 0 & 865 & 812 \\
\hline \multicolumn{12}{|c|}{ POZUELOS } \\
\hline sample & TDS & $\mathrm{Ca}$ & $M_{s}$ & $\mathrm{Na}$ & $\mathrm{K}$ & $\mathrm{Li}$ & $\mathrm{Cl}$ & SO4 & $\begin{array}{r}\mathrm{CO} \\
3\end{array}$ & $\begin{array}{r}\mathrm{HC} \\
\mathrm{O} 3 \\
\end{array}$ & B \\
\hline PZ1 & 237 & $44^{-}$ & 11 & $\begin{array}{r}89,66 \\
1\end{array}$ & 1,011 & 96 & $\begin{array}{r}154,5 \\
21\end{array}$ & 8,864 & 0 & 213 & 650 \\
\hline PZ2 & 291 & .58 & $\begin{array}{r}1,85 \\
4\end{array}$ & $\begin{array}{r}107,7 \\
72\end{array}$ & 2,976 & 207 & $\begin{array}{r}176,2 \\
83\end{array}$ & 9,060 & 0 & 278 & $\begin{array}{r}1,36 \\
6\end{array}$ \\
\hline PZ3 & 290 & $\begin{array}{r}2,3 \\
2\end{array}$ & $\begin{array}{r}2,58 \\
7\end{array}$ & $\begin{array}{r}102,7 \\
15\end{array}$ & 6,314 & 712 & $\begin{array}{r}178,2 \\
50\end{array}$ & $\begin{array}{r}10,78 \\
5\end{array}$ & 0 & 12 & 398 \\
\hline PZ4 & & 604 & $\begin{array}{r}1,81 \\
6\end{array}$ & $\begin{array}{r}115,9 \\
75\end{array}$ & 4,044 & 260 & $\begin{array}{r}198,9 \\
70\end{array}$ & 2,974 & 0 & 0 & $\begin{array}{r}1,65 \\
5\end{array}$ \\
\hline PZ5 & $\angle 54$ & $\begin{array}{r}1,60 \\
5\end{array}$ & $\begin{array}{r}1,71 \\
5\end{array}$ & $\begin{array}{r}87,01 \\
2\end{array}$ & 5,213 & 940 & $\begin{array}{r}150,6 \\
70\end{array}$ & $\begin{array}{r}13,11 \\
5\end{array}$ & 0 & 0 & $\begin{array}{r}2,10 \\
2\end{array}$ \\
\hline PZ6 & 295 & $\begin{array}{r}1,61 \\
0\end{array}$ & $\begin{array}{r}2,09 \\
9\end{array}$ & $\begin{array}{r}102,1 \\
52\end{array}$ & 4,728 & 835 & $\begin{array}{r}190,9 \\
56\end{array}$ & 9,685 & 0 & 0 & 202 \\
\hline PZ7 & 256 & 444 & $\begin{array}{r}1,18 \\
0\end{array}$ & $\begin{array}{r}91,67 \\
4\end{array}$ & 1,024 & 86 & $\begin{array}{r}171,3 \\
60\end{array}$ & 8,812 & 0 & 240 & 415 \\
\hline PZ8 & 205 & 672 & 741 & $\begin{array}{r}76,59 \\
1 \\
\end{array}$ & 816 & 75 & $\begin{array}{r}122,0 \\
34 \\
\end{array}$ & 9,005 & 0 & 266 & 396 \\
\hline \multicolumn{12}{|c|}{ RATONES } \\
\hline sample & TDS & $\mathrm{Ca}$ & $\mathrm{Mg}$ & $\mathrm{Na}$ & $\mathrm{K}$ & $\mathrm{Li}$ & $\mathrm{Cl}$ & SO4 & $\begin{array}{r}\mathrm{CO} \\
3 \\
\end{array}$ & $\begin{array}{r}\mathrm{HC} \\
\mathrm{O} 3 \\
\end{array}$ & B \\
\hline RA1 & 28 & $\begin{array}{r}1,21 \\
3\end{array}$ & 135 & 9,780 & 852 & 88 & $\begin{array}{r}17,26 \\
0\end{array}$ & 2,731 & 0 & 647 & 312 \\
\hline RA2 & 83 & $\begin{array}{r}1,54 \\
0\end{array}$ & 323 & $\begin{array}{r}30,53 \\
3\end{array}$ & 3,205 & 260 & $\begin{array}{r}54,45 \\
7\end{array}$ & 5,125 & 0 & 415 & 433 \\
\hline RA3 & 72 & 1408 & 210 & 27,31 & 3,024 & 125 & 53,19 & 3,580 & 0 & 348 & 509 \\
\hline
\end{tabular}


2

2

\begin{tabular}{|c|c|c|c|c|c|c|c|c|c|c|c|}
\hline \multicolumn{12}{|c|}{ ANTOFALLA } \\
\hline sample & TDS & $\mathrm{Ca}$ & $\mathrm{Mg}$ & $\mathrm{Na}$ & $\mathrm{K}$ & $\mathrm{Li}$ & $\mathrm{Cl}$ & $\mathrm{SO} 4$ & $\begin{array}{r}\mathrm{CO} \\
3 \\
\end{array}$ & $\begin{array}{c}\mathrm{HC} \\
\mathrm{O} 3 \\
\end{array}$ & B \\
\hline AN1 & 55 & $\begin{array}{r}2,96 \\
4\end{array}$ & 705 & $\begin{array}{r}15,97 \\
5\end{array}$ & 2,490 & 164 & $\begin{array}{r}29,05 \\
8\end{array}$ & 8,714 & 0 & 77 & 530 \\
\hline AN2 & 185 & 662 & 725 & $\begin{array}{r}63,71 \\
3\end{array}$ & 3,518 & 615 & $\begin{array}{r}113,9 \\
85\end{array}$ & 7,725 & 0 & 358 & 815 \\
\hline AN3 & 148 & 535 & 816 & $\begin{array}{r}55,77 \\
0\end{array}$ & 807 & 311 & $\begin{array}{r}88,20 \\
1\end{array}$ & 7,815 & 0 & 241 & 878 \\
\hline AN4 & 25 & $\begin{array}{r}1,31 \\
0\end{array}$ & 365 & 6,889 & 365 & 95 & $\begin{array}{r}14,10 \\
0\end{array}$ & 1,830 & 0 & 710 & 814 \\
\hline AN5 & 19 & 692 & 644 & 5,271 & 476 & 46 & 9,460 & 1,005 & 0 & 865 & 807 \\
\hline AN6 & 9 & 286 & 206 & 2,580 & 166 & 25 & 4,873 & 356 & 0 & 492 & 415 \\
\hline \multicolumn{12}{|c|}{ ARIZARO } \\
\hline sample & TDS & $\mathrm{Ca}$ & $\mathrm{Mg}$ & $\mathrm{Na}$ & $\mathrm{K}$ & $\mathrm{L}_{1}$ & $\mathrm{Cl}$ & $\mathrm{SO} 4$ & $\begin{array}{r}\mathrm{CO} \\
3 \\
\end{array}$ & $\begin{array}{r}\mathrm{HC} \\
\mathrm{O} 3 \\
\end{array}$ & B \\
\hline AR0 & 321 & 760 & $\begin{array}{r}1,84 \\
0\end{array}$ & $\begin{array}{r}119,5 \\
00\end{array}$ & 160 & 10 & $\begin{array}{r}190,7 \\
00\end{array}$ & 9,260 & - & - & 138 \\
\hline AR1 & 274 & 415 & 484 & $\begin{array}{r}100,5 \\
81\end{array}$ & 4,112 & 106 & $\begin{array}{r}182,2 \\
13\end{array}$ & $\begin{array}{r}12,48 \\
3\end{array}$ & 0 & 81 & $\begin{array}{r}1,10 \\
9\end{array}$ \\
\hline AR2 & 155 & 473 & 545 & $\begin{array}{r}53,10 \\
7\end{array}$ & $\therefore, 061$ & 83 & $\begin{array}{r}98,09 \\
0\end{array}$ & 5,521 & 0 & 122 & $\begin{array}{r}2,06 \\
6\end{array}$ \\
\hline AR3 & 92 & 512 & $\begin{array}{r}1,61 \\
6\end{array}$ & $\begin{array}{r}23 \cdot .5 \\
6\end{array}$ & 5,686 & 375 & $\begin{array}{r}42,61 \\
1\end{array}$ & $\begin{array}{r}17,62 \\
0\end{array}$ & 0 & 74 & $\begin{array}{r}1,21 \\
6\end{array}$ \\
\hline AR4 & 130 & 517 & $\begin{array}{r}7,73 \\
5\end{array}$ & $\begin{array}{r}5,56 \\
5\end{array}$ & 7,543 & 318 & $\begin{array}{r}58,84 \\
7\end{array}$ & $\begin{array}{r}30,24 \\
6\end{array}$ & 0 & 119 & $\begin{array}{r}3,30 \\
6\end{array}$ \\
\hline AR5 & 308 & 429 & $\begin{array}{r}4,1 \\
1\end{array}$ & $\begin{array}{r}99,47 \\
8\end{array}$ & $\begin{array}{r}10,07 \\
1\end{array}$ & 180 & $\begin{array}{r}184,2 \\
34\end{array}$ & $\begin{array}{r}30,39 \\
0\end{array}$ & 0 & 225 & $\begin{array}{r}3,22 \\
5\end{array}$ \\
\hline AR6 & 80 & & & $\begin{array}{r}24,94 \\
4\end{array}$ & 1,098 & 112 & $\begin{array}{r}39,24 \\
3\end{array}$ & $\begin{array}{r}13,92 \\
3\end{array}$ & 0 & 96 & $\begin{array}{r}1,23 \\
2\end{array}$ \\
\hline AR7 & 105 & & $\begin{array}{r}4,09 \\
2\end{array}$ & $\begin{array}{r}24,99 \\
0\end{array}$ & $\begin{array}{r}10,01 \\
1\end{array}$ & 465 & $\begin{array}{r}56,89 \\
7\end{array}$ & $\begin{array}{r}17,62 \\
0\end{array}$ & 0 & 60 & $\begin{array}{r}1,31 \\
3\end{array}$ \\
\hline AR8 & 48 & 515 & $\begin{array}{r}1,07 \\
0\end{array}$ & $\begin{array}{r}15,56 \\
4\end{array}$ & 1,480 & 52 & $\begin{array}{r}23,46 \\
8\end{array}$ & 7,922 & 0 & 93 & $\begin{array}{r}2,36 \\
6\end{array}$ \\
\hline AR9 & & 432 & 376 & $\begin{array}{r}10,80 \\
5\end{array}$ & 1,315 & 97 & $\begin{array}{r}16,66 \\
2\end{array}$ & 2,497 & 0 & 75 & $\begin{array}{r}3,38 \\
2\end{array}$ \\
\hline AR10 & 64 & 410 & 484 & $\begin{array}{r}22,53 \\
0 \\
\end{array}$ & 1,180 & 122 & $\begin{array}{r}38,53 \\
4 \\
\end{array}$ & 7,682 & 0 & 74 & 380 \\
\hline \multicolumn{12}{|c|}{ POCITOS } \\
\hline sample & TDS & $\mathrm{Ca}$ & $\mathrm{Mg}$ & $\mathrm{Na}$ & $\mathrm{K}$ & $\mathrm{Li}$ & $\mathrm{Cl}$ & $\mathrm{SO} 4$ & $\begin{array}{r}\mathrm{CO} \\
3 \\
\end{array}$ & $\begin{array}{r}\mathrm{HC} \\
\mathrm{O} 3 \\
\end{array}$ & B \\
\hline PC0 & 327 & 600 & $\begin{array}{r}1,29 \\
0\end{array}$ & $\begin{array}{r}123,1 \\
00\end{array}$ & 3,400 & 97 & $\begin{array}{r}190,6 \\
00\end{array}$ & 7,440 & - & - & 708 \\
\hline PC1 & 32 & $\begin{array}{r}1,23 \\
5\end{array}$ & 246 & 9,584 & 421 & 27 & $\begin{array}{r}18,02 \\
0\end{array}$ & 2,690 & 0 & 74 & 70 \\
\hline PC2 & 34 & $\begin{array}{r}1,44 \\
3\end{array}$ & 285 & 9,667 & 105 & 30 & $\begin{array}{r}17,85 \\
9\end{array}$ & 6,240 & 0 & 56 & 85 \\
\hline PC3 & 278 & 795 & $\begin{array}{r}1,22 \\
5\end{array}$ & $\begin{array}{r}102,5 \\
97\end{array}$ & 610 & 101 & $\begin{array}{r}182,2 \\
35\end{array}$ & 9,050 & 0 & 0 & 208 \\
\hline PC4 & 299 & 815 & $\begin{array}{r}1,38 \\
4\end{array}$ & $\begin{array}{r}110,8 \\
62\end{array}$ & 1,197 & 86 & $\begin{array}{r}190,7 \\
50\end{array}$ & 4,300 & 0 & 0 & 194 \\
\hline PC5 & 38 & 1,54 & 260 & 11,44 & 1,488 & 46 & 18,34 & 6,955 & 0 & 37 & 88 \\
\hline
\end{tabular}




\begin{tabular}{|c|c|c|c|c|c|c|c|c|c|c|c|}
\hline & & 0 & & 0 & & & 5 & & & & \\
\hline PC6 & 41 & 412 & 568 & $\begin{array}{r}12,54 \\
4\end{array}$ & 1,670 & 65 & $\begin{array}{r}23,95 \\
0\end{array}$ & 5,272 & 0 & 37 & 170 \\
\hline PC7 & 36 & 645 & 633 & $\begin{array}{r}10,38 \\
0\end{array}$ & 1,771 & 68 & $\begin{array}{r}16,05 \\
5\end{array}$ & 7,925 & 0 & 0 & 162 \\
\hline PC8 & 29 & 408 & 596 & $\begin{array}{r}10,30 \\
1\end{array}$ & 1,612 & 53 & $\begin{array}{r}15,25 \\
2\end{array}$ & 3,897 & 0 & 15 & 60 \\
\hline PC9 & 30 & 944 & 578 & $\begin{array}{r}10,29 \\
8\end{array}$ & 1,644 & 22 & $\begin{array}{r}18,09 \\
5\end{array}$ & 2,102 & 0 & 22 & 63 \\
\hline PC10 & 45 & 365 & 135 & $\begin{array}{r}12,86 \\
3 \\
\end{array}$ & 1,702 & 68 & $\begin{array}{r}20,33 \\
3 \\
\end{array}$ & 9,970 & 0 & 13 & 63 \\
\hline \multicolumn{12}{|c|}{ RINCON } \\
\hline sample & TDS & $\mathrm{Ca}$ & $\mathrm{Mg}$ & $\mathrm{Na}$ & $\mathrm{K}$ & $\mathrm{Li}$ & $\mathrm{Cl}$ & $\mathrm{SO} 4$ & $\begin{array}{r}\mathrm{CO} \\
3\end{array}$ & $\begin{array}{c}\mathrm{HC} \\
\mathrm{O} 3\end{array}$ & B \\
\hline RI0 & 339 & 280 & $\begin{array}{r}2,12 \\
0\end{array}$ & $\begin{array}{r}122,2 \\
00\end{array}$ & 6,570 & 350 & $\begin{array}{r}90,5 \\
60\end{array}$ & $\begin{array}{r}15,99 \\
0\end{array}$ & - & - & $\begin{array}{r}1,60 \\
9\end{array}$ \\
\hline RI1 & 281 & $\begin{array}{r}1,05 \\
0\end{array}$ & $\begin{array}{r}1,81 \\
5\end{array}$ & $\begin{array}{r}95,23 \\
5\end{array}$ & 7,130 & & $\begin{array}{r}1 \%, 9 \\
36\end{array}$ & $\begin{array}{r}17,48 \\
4\end{array}$ & 0 & 150 & $\begin{array}{r}1,90 \\
4\end{array}$ \\
\hline RI2 & 285 & 813 & $\begin{array}{r}2,29 \\
7\end{array}$ & $\begin{array}{r}99,19 \\
9\end{array}$ & 6,543 & $2 / 0$ & $\begin{array}{r}172,5 \\
57\end{array}$ & $\begin{array}{r}25,23 \\
3\end{array}$ & 0 & 134 & $\begin{array}{r}2,09 \\
8\end{array}$ \\
\hline RI3 & 152 & 805 & $\begin{array}{r}2,21 \\
0\end{array}$ & $\begin{array}{r}47,03 \\
0\end{array}$ & $5,6 ? ?$ & 112 & $\begin{array}{r}84,82 \\
3\end{array}$ & $\begin{array}{r}13,31 \\
4\end{array}$ & 0 & 163 & $\begin{array}{r}1,61 \\
2\end{array}$ \\
\hline RI4 & 145 & 833 & $\begin{array}{r}2,28 \\
4\end{array}$ & $\begin{array}{r}47,76 \\
4\end{array}$ & ,,$\$ 41$ & 122 & $\begin{array}{r}83,63 \\
5\end{array}$ & $\begin{array}{r}14,58 \\
4\end{array}$ & 0 & 177 & $\begin{array}{r}1,40 \\
5\end{array}$ \\
\hline RI5 & 140 & $\begin{array}{r}1,10 \\
2\end{array}$ & $\begin{array}{r}1,78 \\
8\end{array}$ & $\begin{array}{r}41, \cdot 4 \\
0\end{array}$ & 6,974 & 360 & $\begin{array}{r}73,81 \\
4\end{array}$ & $\begin{array}{r}15,41 \\
5\end{array}$ & 0 & 210 & $\begin{array}{r}1,81 \\
2\end{array}$ \\
\hline RI6 & 141 & 910 & $\begin{array}{r}2,04 \\
4\end{array}$ & $\begin{array}{r}8,94 \\
5\end{array}$ & 6,530 & 268 & $\begin{array}{r}74,72 \\
2\end{array}$ & $\begin{array}{r}16,11 \\
2\end{array}$ & 0 & 147 & $\begin{array}{r}2,04 \\
1\end{array}$ \\
\hline RI7 & 152 & 930 & $1.8=$ & $\begin{array}{r}50,16 \\
3\end{array}$ & 6,812 & 195 & $\begin{array}{r}96,23 \\
1\end{array}$ & $\begin{array}{r}10,34 \\
1\end{array}$ & 0 & 207 & $\begin{array}{r}1,90 \\
4\end{array}$ \\
\hline RI8 & 183 & 652 & $\begin{array}{r}2, n, \\
0\end{array}$ & $\begin{array}{r}61,24 \\
0\end{array}$ & 7,315 & 651 & $\begin{array}{r}108,3 \\
78\end{array}$ & $\begin{array}{r}11,01 \\
2\end{array}$ & 0 & 215 & $\begin{array}{r}1,41 \\
2\end{array}$ \\
\hline RI9 & 187 & 0.4 & $\begin{array}{r}1,91 \\
8\end{array}$ & $\begin{array}{r}59,15 \\
2\end{array}$ & 7,015 & 337 & $\begin{array}{r}107,5 \\
00\end{array}$ & $\begin{array}{r}10,40 \\
4\end{array}$ & 0 & 219 & $\begin{array}{r}1,78 \\
7\end{array}$ \\
\hline RI10 & 1on & 530 & $\begin{array}{r}2,01 \\
6\end{array}$ & $\begin{array}{r}60,48 \\
8\end{array}$ & 4,916 & 150 & $\begin{array}{r}102,3 \\
34\end{array}$ & $\begin{array}{r}10,48 \\
2\end{array}$ & 0 & 112 & $\begin{array}{r}1,47 \\
0\end{array}$ \\
\hline \multicolumn{12}{|c|}{ RIO GRANDE } \\
\hline sample & TIS & $\mathrm{Ca}$ & $\mathrm{Mg}$ & $\mathrm{Na}$ & K & $\mathrm{Li}$ & $\mathrm{Cl}$ & $\mathrm{SO} 4$ & $\begin{array}{r}\mathrm{CO} \\
3\end{array}$ & $\begin{array}{c}\mathrm{HC} \\
\mathrm{O} 3\end{array}$ & B \\
\hline RG0 & 260 & 800 & $\begin{array}{r}2,60 \\
0\end{array}$ & $\begin{array}{r}92,40 \\
0\end{array}$ & 3,710 & 420 & $\begin{array}{r}148,9 \\
00\end{array}$ & $\begin{array}{r}10,61 \\
0\end{array}$ & - & - & $\begin{array}{r}1,67 \\
3\end{array}$ \\
\hline RG1 & 285 & $\begin{array}{r}1,86 \\
2\end{array}$ & $\begin{array}{r}2,21 \\
5\end{array}$ & $\begin{array}{r}96,48 \\
5\end{array}$ & 3,012 & 336 & $\begin{array}{r}162,8 \\
40\end{array}$ & $\begin{array}{r}18,68 \\
0\end{array}$ & 0 & 416 & 414 \\
\hline $\mathrm{RG} 2$ & 280 & $\begin{array}{r}1,96 \\
6\end{array}$ & $\begin{array}{r}2,19 \\
0\end{array}$ & $\begin{array}{r}98,18 \\
7\end{array}$ & 3,305 & 274 & $\begin{array}{r}163,7 \\
73\end{array}$ & $\begin{array}{r}19,99 \\
0\end{array}$ & 0 & 297 & 302 \\
\hline RG3 & 257 & $\begin{array}{r}1,98 \\
7\end{array}$ & $\begin{array}{r}2,13 \\
6\end{array}$ & $\begin{array}{r}89,37 \\
3\end{array}$ & 3,315 & 468 & $\begin{array}{r}169,0 \\
85\end{array}$ & 8,654 & 0 & 25 & 415 \\
\hline RG4 & 207 & $\begin{array}{r}2,10 \\
4\end{array}$ & $\begin{array}{r}2,23 \\
0\end{array}$ & $\begin{array}{r}77,91 \\
0\end{array}$ & 3,588 & 502 & $\begin{array}{r}131,5 \\
28\end{array}$ & 6,940 & 0 & 76 & 545 \\
\hline RG5 & 260 & $\begin{array}{r}1,97 \\
0\end{array}$ & $\begin{array}{r}1,39 \\
0\end{array}$ & $\begin{array}{r}87,76 \\
1\end{array}$ & 2,469 & 139 & $\begin{array}{r}166,2 \\
35\end{array}$ & 4,974 & 0 & 72 & 348 \\
\hline RG6 & 259 & $\begin{array}{r}2,10 \\
3\end{array}$ & $\begin{array}{r}1,50 \\
5\end{array}$ & $\begin{array}{r}99,82 \\
8\end{array}$ & 2,645 & 152 & $\begin{array}{r}164,6 \\
15\end{array}$ & 5,134 & 0 & 98 & 366 \\
\hline
\end{tabular}




\begin{tabular}{crrrrrrrrrrr} 
RG7 & 252 & 2,10 & 2,23 & 103,4 & 3,316 & 480 & 162,2 & 4,909 & 0 & 44 & 423 \\
& & 0 & 4 & 66 & & & 00 & & & & \\
RG8 & 199 & 1,28 & 2,97 & 74,57 & 2,890 & 692 & 131,6 & 2,022 & 0 & 366 & 315 \\
& & 3 & 4 & 2 & & & 65 & & & & \\
RG 9 & 234 & 2,33 & 2,21 & 78,28 & 3,325 & 475 & 150,7 & 3,080 & 0 & 381 & 442 \\
& 0 & 2 & 8 & & & 55 & & & & \\
RG10 & 226 & 2,04 & 2,08 & 75,34 & 3,191 & 443 & 147,7 & 2,315 & 0 & 337 & 404 \\
\hline
\end{tabular}

- not reported

Table 3. Mean values for hydrochemical compositions of bil. as from Andean salt pans. Values correspond to averages computed on data presented i1. Tal le 2. n: number of samples. TDS in $\mathrm{g} \mathrm{L}^{-1}$, the remaining concentrations in $\mathrm{mg} \mathrm{L}^{-1}$.

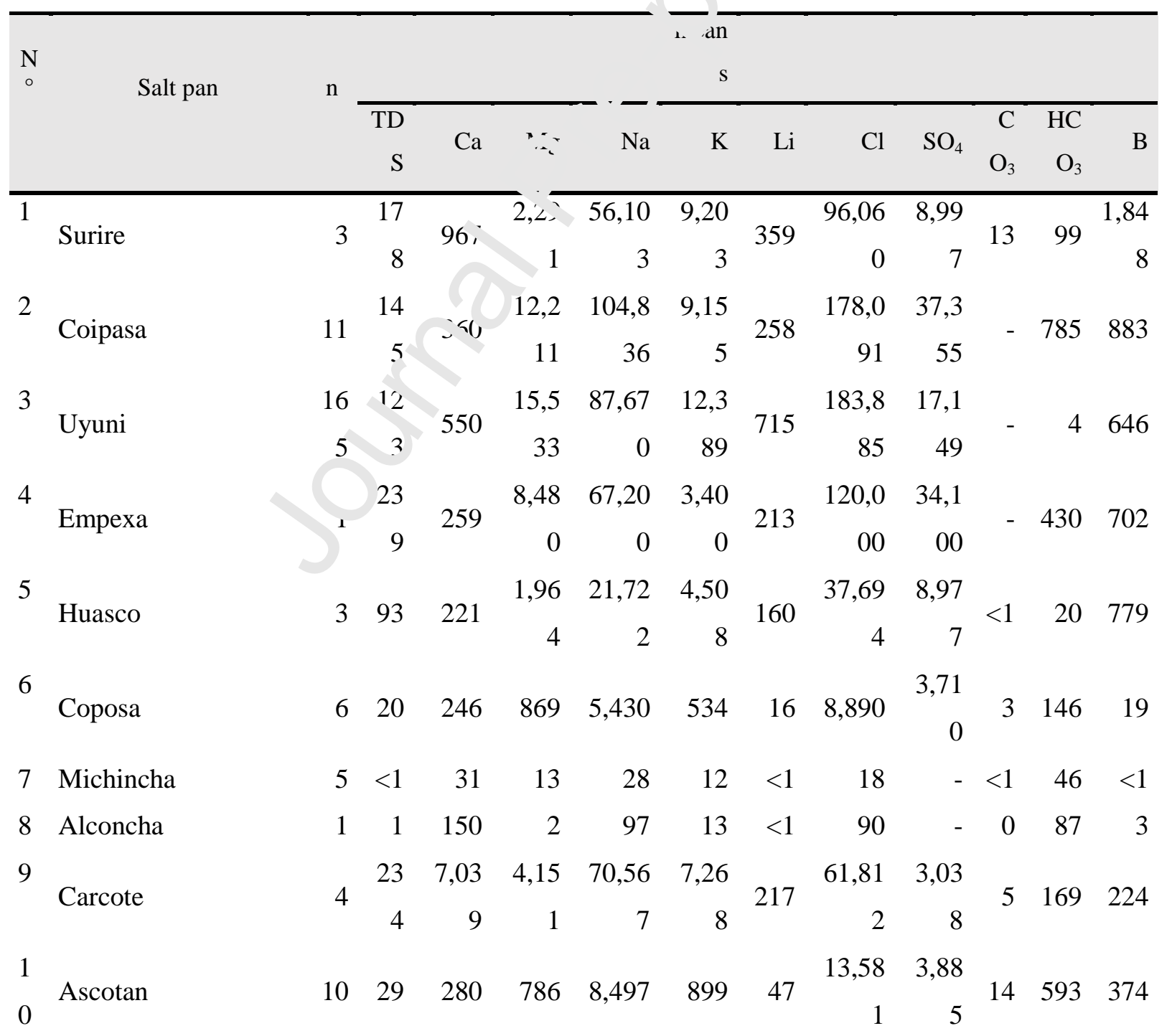




\begin{tabular}{|c|c|c|c|c|c|c|c|c|c|c|c|c|c|}
\hline & Pastos Grandes & \multirow{2}{*}{1} & \multirow{2}{*}{$\begin{array}{r}32 \\
1\end{array}$} & \multirow{2}{*}{$\begin{array}{r}3,10 \\
0\end{array}$} & \multirow{2}{*}{$\begin{array}{r}3,48 \\
0\end{array}$} & \multirow{2}{*}{$\begin{array}{r}101,0 \\
00\end{array}$} & \multirow{2}{*}{$\begin{array}{r}14,2 \\
00\end{array}$} & \multirow{2}{*}{$\begin{array}{r}1,64 \\
0\end{array}$} & \multirow{2}{*}{$\begin{array}{r}194,0 \\
00\end{array}$} & \multirow{2}{*}{$\begin{array}{r}2,46 \\
0\end{array}$} & & \multicolumn{2}{|c|}{3,04} \\
\hline 1 & (Altiplano) & & & & & & & & & & & & 1 \\
\hline & \multirow{2}{*}{ tacama } & \multirow{2}{*}{10} & 18 & \multirow{2}{*}{606} & 4,06 & 46,79 & 8,70 & \multirow{2}{*}{562} & 90,04 & 9,85 & \multirow{2}{*}{$<1$} & \multirow{2}{*}{273} & \multirow{2}{*}{482} \\
\hline & & & 1 & & 4 & 3 & 6 & & 7 & 6 & & & \\
\hline & El Tara & 12 & 35 & 346 & 165 & $\begin{array}{r}22,50 \\
4\end{array}$ & 243 & 140 & $\begin{array}{r}35,24 \\
0\end{array}$ & $\begin{array}{r}3,08 \\
3\end{array}$ & 12 & 772 & 201 \\
\hline & $\begin{array}{l}\text { Aguas Calientes } \\
\text { Norte }\end{array}$ & 7 & 10 & 633 & 151 & 4,414 & 165 & 25 & 7,964 & 541 & 1 & 281 & 66 \\
\hline & & 10 & - & 260 & 376 & 15,73 & 1,13 & & 18,67 & 12,4 & 34 & & \\
\hline & 1 lajóa & 10 & 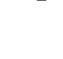 & & & 1 & 0 & & 0 & 00 & 9 & & \\
\hline & Loyoques o & 5 & 04 & 11,4 & 1,96 & 53,69 & & & 141,9 & 1,61 & 8 & 90 & \\
\hline & Quisquiro & & & 54 & 0 & 8 & & & 13 & 5 & & & \\
\hline & Aguas Calientes & 5 & 17 & 1,22 & 046 & 6060 & & 5 & 12,46 & 1,74 & 0 & & \\
\hline & Centro & & & 5 & & & & & 0 & 0 & & & \\
\hline & El Laco & 6 & 62 & & 2,37 & $22,3 \mathrm{C}$ & 1,73 & 7 & 38,58 & 6,34 & 0 & 393 & 80 \\
\hline & He Lave & & & & 2 & & 7 & & 3 & 1 & 0 & 393 & 180 \\
\hline & Aguas Calientes Sur & 8 & 7 & 432 & & 2,509 & 189 & 4 & 4,660 & 1,06 & 0 & 167 & 0 \\
\hline & & & & & & & & & & 2 & & & \\
\hline & Imilac & 4 & 5 & & 32 & 8,948 & 49 & 19 & 2,374 & 801 & 4 & 59 & 4 \\
\hline & Punta Negra & 6 & 2 & & 18 & 718 & 61 & 1 & 1,255 & 144 & 6 & 56 & 5 \\
\hline & Aguas Calientes Sur & & & & 131 & 1668 & 163 & 5 & 2718 & 1,01 & 7 & 108 & 19 \\
\hline & Sur & & & & & & & & & 4 & & & \\
\hline & Paianoles & & & 3,23 & 1,56 & 19,43 & 1,22 & 25 & 45,58 & 1,81 & 0 & 283 & 160 \\
\hline & & & & 4 & 0 & 7 & 1 & & 8 & 0 & & & \\
\hline & $\mathrm{I}_{0}$ & & 28 & 441 & 34,4 & 42,31 & 10,7 & 61 & 121,1 & 65,8 & 0 & 36 & 532 \\
\hline & 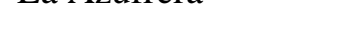 & & 7 & & 00 & 7 & 73 & & 57 & 34 & o & & \\
\hline & Gorhea & 5 & 58 & 288 & 26,8 & 47,06 & 3,92 & 316 & 114,0 & 72,3 & 0 & 0 & 2,31 \\
\hline & Soridena & & & & 10 & 0 & 5 & & 70 & 89 & 0 & & 9 \\
\hline & Ignorados & 2 & 11 & 495 & 576 & 490 & 490 & 2 & 927 & 6,89 & 0 & 0 & 24 \\
\hline & & & & & & & & & & 5 & & & \\
\hline & A & 6 & 75 & 16,6 & 2,41 & 34,78 & 1,42 & & 92,09 & 1,09 & 0 & 21 & 311 \\
\hline & Mgua & 0 & & 52 & 1 & 3 & 9 & & 8 & 5 & 0 & 121 & ז \\
\hline & & 3 & 11 & 51,6 & 6,60 & 60,66 & 2,60 & & 203,3 & 461 & 0 & 917 & 739 \\
\hline & ar & & 3 & 67 & 0 & 7 & 0 & & 34 & & & & \\
\hline
\end{tabular}




\begin{tabular}{|c|c|c|c|c|c|c|c|c|c|c|c|c|c|}
\hline & La Isla & 12 & 62 & 390 & $\begin{array}{r}2,57 \\
8\end{array}$ & $\begin{array}{r}46,66 \\
7\end{array}$ & $\begin{array}{r}10,8 \\
98\end{array}$ & 402 & $\begin{array}{r}87,27 \\
8\end{array}$ & $\begin{array}{r}7,01 \\
5\end{array}$ & 4 & 188 & 118 \\
\hline & Las Parinas & 6 & 46 & 300 & $\begin{array}{r}1,18 \\
5\end{array}$ & $\begin{array}{r}36,31 \\
7\end{array}$ & $\begin{array}{r}1,11 \\
4\end{array}$ & 130 & $\begin{array}{r}59,60 \\
7\end{array}$ & $\begin{array}{r}4,50 \\
1\end{array}$ & 0 & 326 & 148 \\
\hline & Pedernales & 4 & 1 & 143 & 47 & 735 & 53 & 3 & 1,285 & 342 & 2 & 112 & 10 \\
\hline & Maricunga & 3 & 19 & 517 & 252 & 5,988 & 485 & 36 & $\begin{array}{r}11,30 \\
9\end{array}$ & 172 & 0 & 167 & 26 \\
\hline & Incahuasi & 5 & 82 & $\begin{array}{r}1,10 \\
3\end{array}$ & $\begin{array}{r}11,2 \\
14\end{array}$ & 9,705 & $\begin{array}{r}5,70 \\
5\end{array}$ & 95 & $\begin{array}{r}57,98 \\
3\end{array}$ & 712 & 0 & 145 & 436 \\
\hline & Antofalla-Botijuelas & 6 & 73 & $\begin{array}{r}1,07 \\
5\end{array}$ & 577 & $\begin{array}{r}25,03 \\
3\end{array}$ & $\begin{array}{r}1,30 \\
4\end{array}$ & & $\begin{array}{r}43,28 \\
0\end{array}$ & $\begin{array}{r}4,57 \\
4\end{array}$ & 0 & 457 & 710 \\
\hline & Río Grande & 11 & $\begin{array}{r}24 \\
7\end{array}$ & $\begin{array}{r}1,86 \\
9\end{array}$ & $\begin{array}{r}2,16 \\
1\end{array}$ & $\begin{array}{r}88,51 \\
0\end{array}$ & $\begin{array}{r}3,1 \\
1\end{array}$ & 0 & $\begin{array}{r}154,4 \\
87\end{array}$ & $\begin{array}{r}7,93 \\
7\end{array}$ & 0 & 211 & 513 \\
\hline & Arizaro & 11 & $\begin{array}{r}14 \\
7\end{array}$ & 497 & $\begin{array}{r}2,08 \\
2\end{array}$ & $\begin{array}{r}47,32 \\
\mathrm{C}\end{array}$ & $\begin{array}{r}4,15 \\
j\end{array}$ & 188 & $\begin{array}{r}84,68 \\
2\end{array}$ & $\begin{array}{r}14,1 \\
06\end{array}$ & 0 & 102 & 1,79 \\
\hline & Hombre Muerto & 6 & $\begin{array}{r}16 \\
7\end{array}$ & 805 & 954 & $\begin{array}{r}5=46 \\
3\end{array}$ & $\begin{array}{r}5,45 \\
8\end{array}$ & 628 & $\begin{array}{r}105,9 \\
48\end{array}$ & $\begin{array}{r}2,81 \\
1\end{array}$ & 0 & 165 & 950 \\
\hline & Diablillos & 4 & 56 & $\begin{array}{r}1,11 \\
9\end{array}$ & $\begin{array}{r}1,{ }^{2} ? \\
6\end{array}$ & $\begin{array}{r}14,94 \\
9\end{array}$ & $\begin{array}{r}3,92 \\
0\end{array}$ & 180 & $\begin{array}{r}28,23 \\
5\end{array}$ & $\begin{array}{r}6,86 \\
5\end{array}$ & 0 & 323 & 592 \\
\hline & Ratones & 3 & & 1,38 & 223 & $\begin{array}{r}22,54 \\
2\end{array}$ & $\begin{array}{r}2,36 \\
0\end{array}$ & 158 & $\begin{array}{r}41,63 \\
6\end{array}$ & $\begin{array}{r}3,81 \\
2\end{array}$ & 0 & 470 & 418 \\
\hline & Centenario & & & 586 & $\begin{array}{r}2,29 \\
3\end{array}$ & $\begin{array}{r}26,50 \\
3\end{array}$ & $\begin{array}{r}3,13 \\
0\end{array}$ & 288 & $\begin{array}{r}46,44 \\
4\end{array}$ & $\begin{array}{r}10,5 \\
51\end{array}$ & 0 & 431 & 971 \\
\hline & Pocitos-Quirón & & 8 & 837 & 655 & $\begin{array}{r}38,51 \\
2\end{array}$ & $\begin{array}{r}1,42 \\
0\end{array}$ & 60 & $\begin{array}{r}64,68 \\
1\end{array}$ & $\begin{array}{r}5,98 \\
6\end{array}$ & 0 & 25 & 170 \\
\hline & Pozuelos & 8 & $\begin{array}{r}26 \\
6\end{array}$ & $\begin{array}{r}1,07 \\
2\end{array}$ & $\begin{array}{r}1,64 \\
1\end{array}$ & $\begin{array}{r}96,69 \\
4\end{array}$ & $\begin{array}{r}3,26 \\
6\end{array}$ & 401 & $\begin{array}{r}167,8 \\
80\end{array}$ & $\begin{array}{r}9,03 \\
8\end{array}$ & 0 & 126 & 898 \\
\hline & $\begin{array}{l}\text { Pastos Grandes } \\
\text { (Puna) }\end{array}$ & 6 & $\begin{array}{r}19 \\
8\end{array}$ & 640 & $\begin{array}{r}4,15 \\
5\end{array}$ & $\begin{array}{r}65,17 \\
7\end{array}$ & $\begin{array}{r}3,55 \\
2\end{array}$ & 476 & $\begin{array}{r}122,0 \\
93\end{array}$ & $\begin{array}{r}7,47 \\
2\end{array}$ & 0 & 904 & 879 \\
\hline & Rincón & 11 & $\begin{array}{r}19 \\
9\end{array}$ & 823 & $\begin{array}{r}2,03 \\
2\end{array}$ & $\begin{array}{r}65,69 \\
6\end{array}$ & $\begin{array}{r}6,33 \\
3\end{array}$ & 287 & $\begin{array}{r}115,5 \\
85\end{array}$ & $\begin{array}{r}14,5 \\
79\end{array}$ & 0 & 173 & $\begin{array}{r}1,73 \\
2\end{array}$ \\
\hline & Cauchari & 5 & $\begin{array}{r}11 \\
9\end{array}$ & 600 & $\begin{array}{r}1,74 \\
6\end{array}$ & $\begin{array}{r}83,88 \\
6\end{array}$ & $\begin{array}{r}4,75 \\
7\end{array}$ & 860 & $\begin{array}{r}130,8 \\
67\end{array}$ & $\begin{array}{r}12,3 \\
06\end{array}$ & 0 & 442 & 2,15 \\
\hline & Olaroz & 10 & $\begin{array}{r}15 \\
4\end{array}$ & 516 & $\begin{array}{r}2,00 \\
2\end{array}$ & 98,84 & 6,22 & 1,01 & 180,7 & $\begin{array}{r}10,0 \\
77\end{array}$ & 0 & 344 & 2,53 \\
\hline
\end{tabular}




\begin{tabular}{llrrrrrrrrrrrr}
5 & Jama & 10 & 32 & 527 & 228 & 20,42 & 1,46 & 82 & 32,30 & 6,63 & 0 & 309 & 983 \\
3 & & & & & & 4 & 9 & & 6 & 3 & & & \\
5 & Salinas Granes & 10 & 10 & 1,52 & 1,06 & 73,25 & 4,13 & & 126,6 & 2,08 & & & \\
4 & & & 7 & 0 & 8 & 5 & 5 & & 63 & 2 & 0 & 314 & 447 \\
5 & Guayatayoc & 3 & 72 & 1,57 & & 28,03 & 16,6 & & 185,4 & 11,3 & & & \\
5 & & & & 9 & & 3 & 47 & & 63 & 53 & 0 & 315 & 360 \\
\hline
\end{tabular}

Table 4. Summary of mean, maximum (max), and concent atio 1 ratios of $\mathrm{Li}^{+}$and $\mathrm{Mg}^{2+}$ in brines from Andean salt pans. The ${ }^{*}$ values for the At: can a brines follow Moraga et al. (1974), Ide and Kunasz (1989), and Kunasz (2006). Tht ${ }^{*}$ mean $\mathrm{Li}^{+}$concentration for Olaroz is from García et al. (2019). Remaining values anc rat os correspond to data presented in Table 3.

\begin{tabular}{|c|c|c|c|c|c|c|c|}
\hline $\begin{array}{l}\mathrm{N} \\
\mathrm{0}\end{array}$ & salt pan & $\begin{array}{l}\text { mean } \mathrm{Li}^{+} \\
\left.(\mathrm{mg} \mathrm{L})^{-1}\right)\end{array}$ & $\begin{array}{c}\mathrm{Mg}{ }^{2} \\
\left({ }^{2} \cdot \mathrm{L}^{-1}\right)\end{array}$ & $\begin{array}{l}\max \mathrm{Li}^{+} \\
\left(\mathrm{mg} \mathrm{L}^{-1}\right)\end{array}$ & $\begin{array}{c}\max \mathrm{Mg}^{2+} \\
\left(\mathrm{mg} \mathrm{L}^{-1}\right)\end{array}$ & $\begin{array}{c}\mathrm{Mg}: \mathrm{Li} \\
\text { mean } \\
\text { ratio }\end{array}$ & $\begin{array}{c}\text { max:mea } \\
\mathrm{n} \\
\text { Li ratio }\end{array}$ \\
\hline 1 & Surire & 359 & $2, \overline{291}$ & 540 & 3,830 & 6 & 2 \\
\hline 2 & Coipasa & & 12,211 & 416 & 23,000 & 47 & 2 \\
\hline 3 & Uyuni & 7.5 & 15,533 & 4,720 & 75,300 & 22 & 7 \\
\hline 4 & Empexa & 213 & 8,480 & 213 & 8,480 & 40 & 1 \\
\hline 5 & Huasco & 160 & 1,964 & 480 & 5,880 & 12 & 3 \\
\hline 6 & Coposa & 16 & 869 & 90 & 4,930 & 56 & 6 \\
\hline 7 & Michincha & $<1$ & 13 & $<1$ & 25 & 641 & 2 \\
\hline 8 & Alconcha & $<1$ & 2 & $<1$ & 2 & 16 & 1 \\
\hline 9 & Carcote & 217 & 4,151 & 339 & 6,850 & 19 & 2 \\
\hline 0 & Ascotan & 47 & 786 & 245 & 5,125 & 17 & 5 \\
\hline 1 & $\begin{array}{l}\text { Pastos Grandes } \\
\text { (Altiplano) }\end{array}$ & 1,640 & 3,480 & 1,640 & 3,480 & 2 & 1 \\
\hline 2 & Atacama & $\begin{array}{l}562- \\
1,400^{*}\end{array}$ & 4,064 & $\begin{array}{l}1,570- \\
6,400^{*}\end{array}$ & $\begin{array}{l}9,650- \\
80,000^{*}\end{array}$ & 7 & $3-5^{*}$ \\
\hline 1 & El Tara & 140 & 165 & 420 & 440 & 1 & 3 \\
\hline
\end{tabular}


3

$\begin{array}{llllllll}1 & \text { Aguas Calientes Norte } & 25 & 151 & 130 & 820 & 6 & 5\end{array}$$$
6
$$$$
1
$$$$
7
$$$$
\text { Aguas Calientes Centro }
$$

89

376

400

286

1,960

425

15

946

45

7,981

63

3

1

8

El Laco

37

2,372

101

6,250

64

3

$$
1
$$

2

1

Imilac

19

265

17

1,370

67

4

2$$
2
$$

Punta Negra

18

3

53

$18 \quad 3$

2 3

Aguas Calientes Sur Sur

13.

35

1,311

25

7

4

25

1,560

62

5,200

63

3

2

$$
5
$$

La Azufrera

51

34,400

86

48,640

562

2

6

216

26,810

500

4,225

85

2

2

7

Ignorados

2

576

2

707

339

2

8

60

2,411

157

39,500

40

3

2

9

36

3

0

La Isla

402

2,578

1,150

8,300

6

3

3

2 Las Parinas

130

1,185

400

3,600

9

3

3 Pedernales

3

47

3

58

$15 \quad 1$




\begin{tabular}{|c|c|c|c|c|c|c|}
\hline Maricunga & 36 & 252 & 92 & 680 & 7 & 3 \\
\hline Incahuasi & 95 & 11,214 & 145 & 15,896 & 118 & 2 \\
\hline Antofalla-Botijuelas & 209 & 577 & 615 & 816 & 3 & 3 \\
\hline Rio Grande & 398 & 2,161 & 692 & 2,234 & 5 & 2 \\
\hline Arizaro & 188 & 2,082 & 465 & 7,736 & 11 & 2 \\
\hline Hombre Muerto & 628 & 954 & 1,01 & 1,915 & 2 & 2 \\
\hline Diablillos & 180 & 1,226 & & 1,884 & 7 & 2 \\
\hline Ratones & 158 & 223 & 260 & 323 & 1 & 2 \\
\hline Centenario & 288 & $? .2 \times 3$ & 1,020 & 7,550 & 8 & 4 \\
\hline Pocitos-Quirón & 60 & $\lcm{55}$ & 101 & 1,384 & 11 & 2 \\
\hline Pozuelos & & 1,641 & 940 & 2,587 & 4 & 2 \\
\hline Pastos Grandes (Puna) & $\therefore 76$ & 4,155 & 857 & 5,647 & 9 & 2 \\
\hline Rincon & 287 & 2,032 & 651 & 2,297 & 7 & 2 \\
\hline Cacuhari & 860 & 1,746 & 1,740 & 2,104 & 2 & 2 \\
\hline Olaroz & $\begin{array}{r}1,014 \\
841^{*}\end{array}$ & 2,002 & 1,213 & 2,301 & 2 & 1 \\
\hline Jama & 82 & 228 & 262 & 492 & 3 & 3 \\
\hline Salinas Grandes & 332 & 1,068 & 1,018 & 2,289 & 3 & 3 \\
\hline Guayatayoc & 96 & 183 & 125 & 183 & 2 & 1 \\
\hline
\end{tabular}




\section{Highlights}

- Sizes of Andean salt pans are proportional to the extent of their endorheic basin.

- The equation mean $\mathrm{Li} \approx 1 / 2 \max \mathrm{Li}$ is a tool for surveying of brine-type deposits.

- The greatest Li levels are expected to be found in largest ana vldest salt pans. 